University of Rhode Island

DigitalCommons@URI

Open Access Master's Theses

1995

\title{
The Effectiveness of Facilitated Discussions in REsolving Conflict at the New Bedford Harbor Suspended Site
}

Thomas C. Ardito

University of Rhode Island

Follow this and additional works at: https://digitalcommons.uri.edu/theses

\section{Recommended Citation}

Ardito, Thomas C., "The Effectiveness of Facilitated Discussions in REsolving Conflict at the New Bedford Harbor Suspended Site" (1995). Open Access Master's Theses. Paper 1386.

https://digitalcommons.uri.edu/theses/1386

This Thesis is brought to you for free and open access by DigitalCommons@URI. It has been accepted for inclusion in Open Access Master's Theses by an authorized administrator of DigitalCommons@URI. For more information, please contact digitalcommons-group@uri.edu. 


\section{THE EFFECTIVENESS OF FACILITATED DISCUSSIONS}

IN RESOLVING CONFLICT

AT THE NEW BEDFORD HARBOR SUPERFUND SITE

BY

THOMAS C. ARDITO

A THESIS SUBMITTED IN PARTIAL FULFILLMENT OF THE REQUIREMENTS FOR THE DEGREE OF MASTER OF ARTS

IN

MARINE AFFAIRS 


\section{MASTER OF ARTS THESIS \\ OF}

THOMAS C. ARDITO

\section{APPROVED :}

Thesis Committee Major Professor

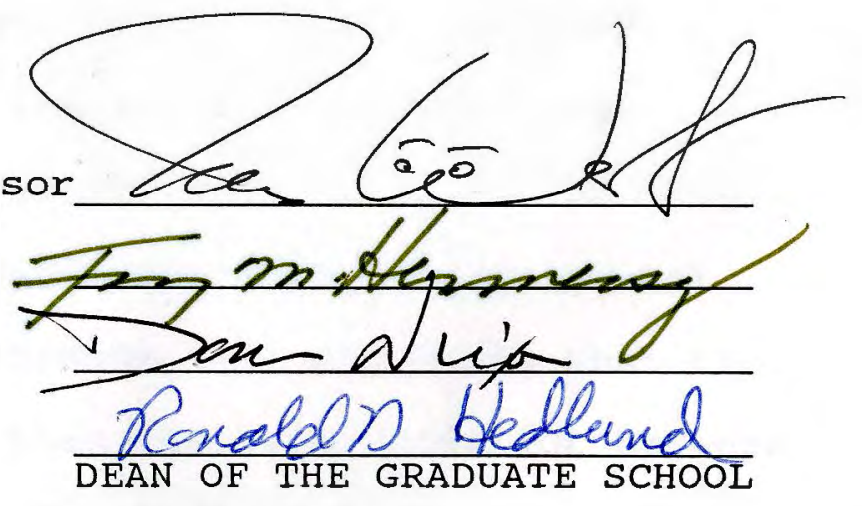




\section{ABSTRACT}

This study examined a case of conflict between Federal decision-makers and local citizens regarding the selection of a clean-up plan for a coastal area contaminated by hazardous wastes. A prolonged dispute over remediation of the New Bedford Harbor Superfund Site resulted in a series of facilitated discussions intended to resolve the conflict. A descriptive survey was used to explore the effect of the discussions upon the risk perceptions of citizens and managers, thereby examining the effectiveness of the facilitated discussions in resolving conflict at the site. The study found that the facilitated discussions did not cause risk perceptions to converge, and concluded that the discussions averted, rather than resolved, conflict between citizens and managers at the New Bedford Harbor Superfund Site. 


\section{ACKNOWLEDGEMENTS}

I wish to thank Dr. Niels west for his unflagging enthusiasm; Mary Lauzon for her unqualified support; and all those living or working in the New Bedford area who made this study possible by taking the time to answer my many questions and complete my many surveys. 


\section{PREFACE}

The research which is the subject of this paper was carried out in 1994 and early 1995. The descriptive survey, by means of which the data was collected, was administered in the summer of 1994.

Survey administration was more difficult than expected. The survey concerned a controversial issue; therefore, while the cooperation of potential subjects was generally good, passions and fear ran high at times. New Bedford is not a particularly easy place to survey, for the same reasons Federal decision-makers have had difficulty communicating there: its poverty and ethnicity.

Analysis turned out to be somewhat problematical, as well. The small size of three of the four study groups meant that the statistical analyses had less power than would have been optimal. More significant, the study's analytical results caused rejection of not just the major hypothesis, but some of the study's assumptions, as well. Results therefore forced a reexamination of the problem itself, rather than providing a simple resolution.

The landscape of Superfund has changed since the study was conceived and the survey administered. At the time of this writing, the statute stands as described herein, and the discussion of caselaw is current. However, while the 103rd Congress was moving toward expansion of Superfund's public participation requirements, the 104th is moving 
toward gutting environmental legislation, generally. It remains to be seen what shape, if any, superfund takes in the 104th Congress.

Regardless, it is hoped that the conclusions drawn herein are pertinent, not just to superfund, but to citizen involvement in environmental decisionmaking, generally. To the extent that this hope is fulfilled, I must thank Drs. West, Nixon, and Hennessey, as well as the many people who completed the survey. To the extent that it is not, the responsibility is mine, alone.

T. C. Ardito

Washington, D.C.

15 March 1995 
I. Introduction: The context of the problem.

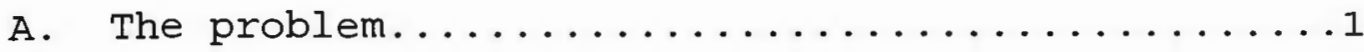
B. New Bedford Area: Geography................
C. The New Bedford Harbor Superfund Site.........11
D. Public involvement in Superfund decisionmaking..19

II. The Problem.
A. Difficulty of siting noxious facilities......57
B. Review of related literature.............59
C. Significance of the study..............69

III. The method.
A. Hypotheses....................... . 70
B. Study area and sample population..........76
C. Survey design....................78
D. Survey administration................

IV. Analysis
A. Description of sample by group...........88
B. Analytical approach....................
C. Analysis........................... 97
D. An emergent relationship: Polarization........100
E. Trust in government; expectation of benefits...117 
V. Conclusions.

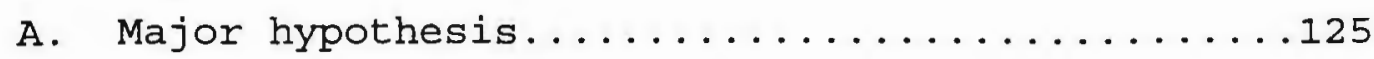

A. Discussion of other findings............ 127

B. The New Bedford Harbor Superfund Site and the reauthorization of CERCLA.............134 Appendices.

A. Disputants' concerns: January 4, 1995.......137

B. Survey texts and cover letters............142

C. List of Acronyms.................. 173

Bibliography.......................... 


\section{LIST OF FIGURES}

Figure I.1: Concentrations of PCBs in Acushnet sediments..5

Figure I.2: Fishing Closure Areas................

Figure I.3: The New Bedford Harbor Superfund Site.......13

Figure I.4: Hot Spot Operable Unit...............15

Figure I.5: Lower Harbor / Bay Operable Unit.........16 


\section{Introduction: The context of the problem.}

\section{A. The problem.}

The siting of noxious facilities has become a most intransigent problem for public environmental policy. Nationally, the defeat of proposals to site such projects has become more the rule than the exception (O'Hare and Sanderson, 1993).

The case of the New Bedford Harbor Superfund Site presents a timely example of the derailment of Federal environmental policy as a result of opposition to the siting of a "locally undesirable land use," or LULU. Twice (first in 1984, then again in 1994) residents of the New Bedford area have forced the United States Environmental Protection Agency (USEPA) to abandon or modify published remediation plans for $\mathrm{PCB}$-contaminated marine sediments in the Acushnet River. In August, 1994, yielding to public sentiment, USEPA Region I cancelled a contract to incinerate the most contaminated Acushnet sediments, in spite of a 1990 Record of Decision (ROD) calling for incineration (Ciavettieri, 1994). The cost of cancelling that one contract has not yet been negotiated, but will undoubtedly be considerable (MacNeil 1994).

Governmental and citizens' representatives have been taking part in a series of facilitated discussions in an attempt to reconcile their differences over the remediation 
of New Bedford Harbor. The success or failure of this effort has bearing on the future of superfund and on citizen participation in governmental decisionmaking, generally. This study examines the effectiveness of these facilitated discussions in resolving perceptual differences between citizens and managers, regarding the risks of the New Bedford Harbor Superfund Site. In so doing, it seeks to illuminate the nature of the conflict itself, within the context of risk perception and communication, regarding a specific marine hazardous waste site in Southeastern Massachusetts. 


\section{B. New Bedford area: Geography.}

\section{B. 1. Historical and economic geography.}

The Acushnet River is a small estuary in Southeastern Massachusetts, opening onto Buzzards Bay. The mouth of this estuary forms a well-protected harbor, New Bedford Harbor, which has been used for commercial purposes since English settlement in the early 18th Century. By the mid-1700s, the river had become an important center of shipbuilding and whaling, and the towns on its banks--New Bedford, Acushnet, and Fair Haven--prospered and grew. By the middle of the 19th Century, New Bedford had become the largest whaling port in the world (Ellis 1892).

Manufacturing also began in the 18th Century in the New Bedford area, albeit on a small scale. During the Nineteenth

Century, however, as the whaling trade began to decline, the great capital which had been accumulated by whaling interests began to be shifted into manufacturing; while textile mills made up the most important segment of this industry, a great diversity of production facilities arose (Hegerty 1959). In the late 19th and early 20 th centuries, dozens of these vast mills were built in brick. With the mills came the tenements, or "triple-deckers:" three-story frame structures built to house the laborers who, with their families, migrated to New Bedford to fuel this industrial expansion. The mills--many vacant now, or partially so--and 
the tenements dominate the areas surrounding the Acushnet River to this day.

Architecture is not the only legacy which New Bedford's industrial growth left upon the area's environment. From the 1940's until the late 1970's, manufacturers of electrical equipment dumped industrial wastes into the Acushnet River, New Bedford Harbor, and adjacent waters. The wastes contained a number of toxic organic and inorganic substances, including: polychlorinated biphenyls (PCBs), polyaromatic hydrocarbons (PAHs), lead, cadmium, chromium, and copper (Pruell et al. 1990; USEPA 1992C, 1989).

Resulting levels of contamination in estuarine sediments ranged as high as 200,000 parts per million (ppm) PCBs $^{1}$ (Fig. I.1) with metals concentrations as high as 4,000 ppm (USEPA 1989a; USEPA 1992C). Pruell et al. (1990) have stated that the Acushnet River may constitute the worst instance of marine $\mathrm{PCB}$ pollution in the nation. High concentrations of PCBs and metals remain in the area's marine biota while elevated levels of PCBs are present in the air surrounding the most contaminated areas (USEPA 1989b; USEPA 1992C).

${ }^{1} 50 \mathrm{ppm}$ PCBs is the concentration above which a substance is considered toxic waste for purposes of the Toxic Substances and Control Act, 15 U.S.C. Section 2601 et seq. See 40 C.F.R. 761.60 and 761.125 . 


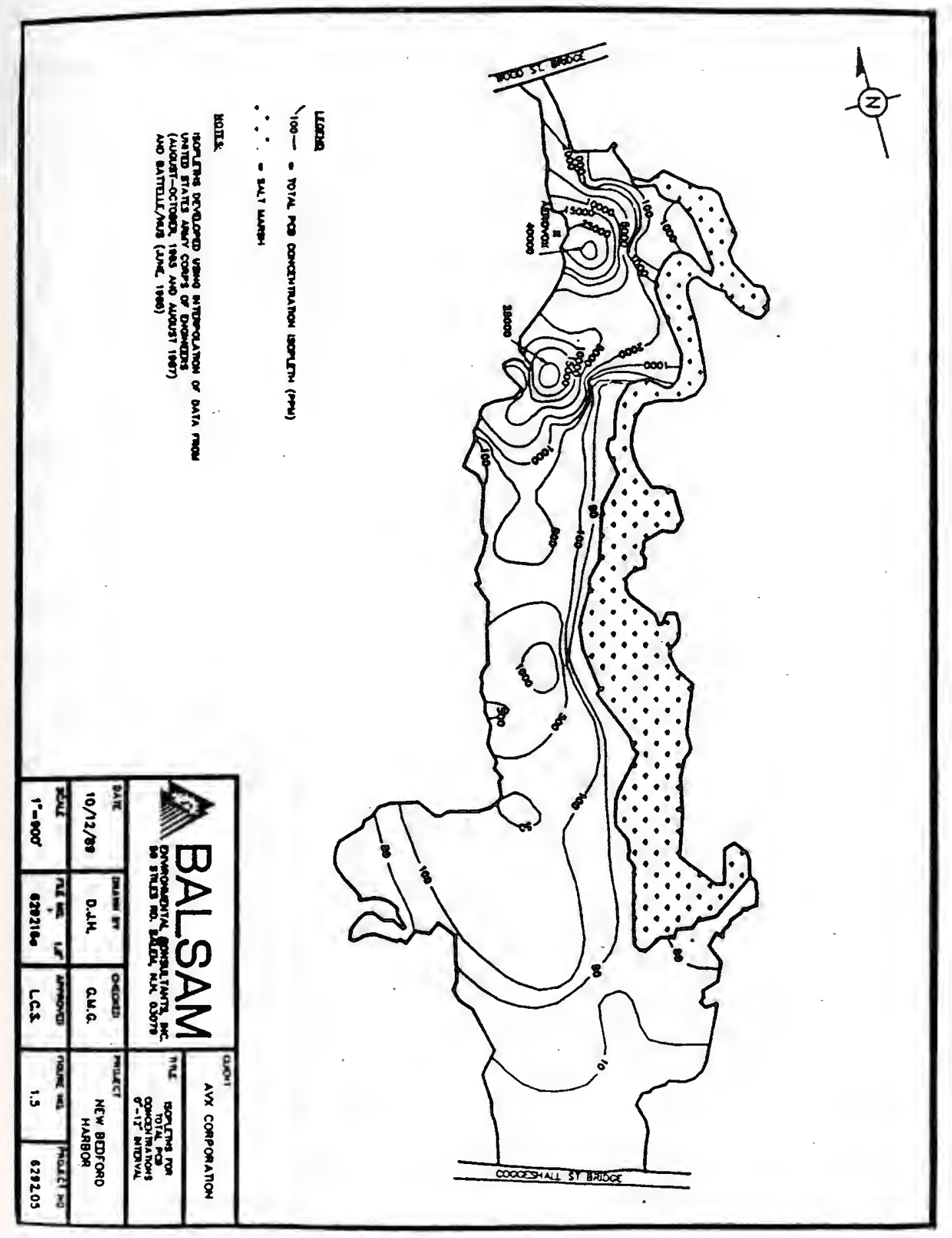

Figure I.1: Concentrations of PCBs in Acushnet sediments. Source: USEPA, $1990 \mathrm{C}$. 
The contamination of the Acushnet River and New Bedford Harbor has affected the towns adjoining the estuary in a number of ways. Since 1979 the harbor has been closed to all fishing (Fig. I.2), while lobstering is illegal in over 18,000 acres of once-productive ground (USEPA 1992C). Risk assessments (RAs) commissioned by USEPA estimate the maximum probable lifetime carcinogenic health risk resulting from multiple-pathway exposure to ambient levels of PCBs in the most contaminated area of the harbor at 3.65 in 1000 (USEPA 1989b). The same methodology finds that lifetime carcinogenic risks from ingestion of New Bedford Harbor seafood might range from 7 in 100 to 2.4 in 10,000 , depending upon the type of seafood and frequency of consumption (USEPA 1992b) ${ }^{2}$.

Research suggests an economic dimension to the damage resulting from the pollution, as well. A study by the National Oceanographic and Atmospheric Administration (NOAA) estimated total economic losses from New Bedford's PCB pollution at $\$ 39.6$ to $\$ 52.4$ million, the result of fishing and beach closures as well as reduced amenity values.

2 These high-end estimates presuppose almost impossible circumstances. The multiple-pathway RA assumes that an individual would eat fish, ingest sediments, and come in direct contact with sediments from the Hot spot for her entire life. The seafood RA is based upon the consumption of a PCBcontaminated lobster from the inner harbor, including the tomalley (liver), every day of one's life. 


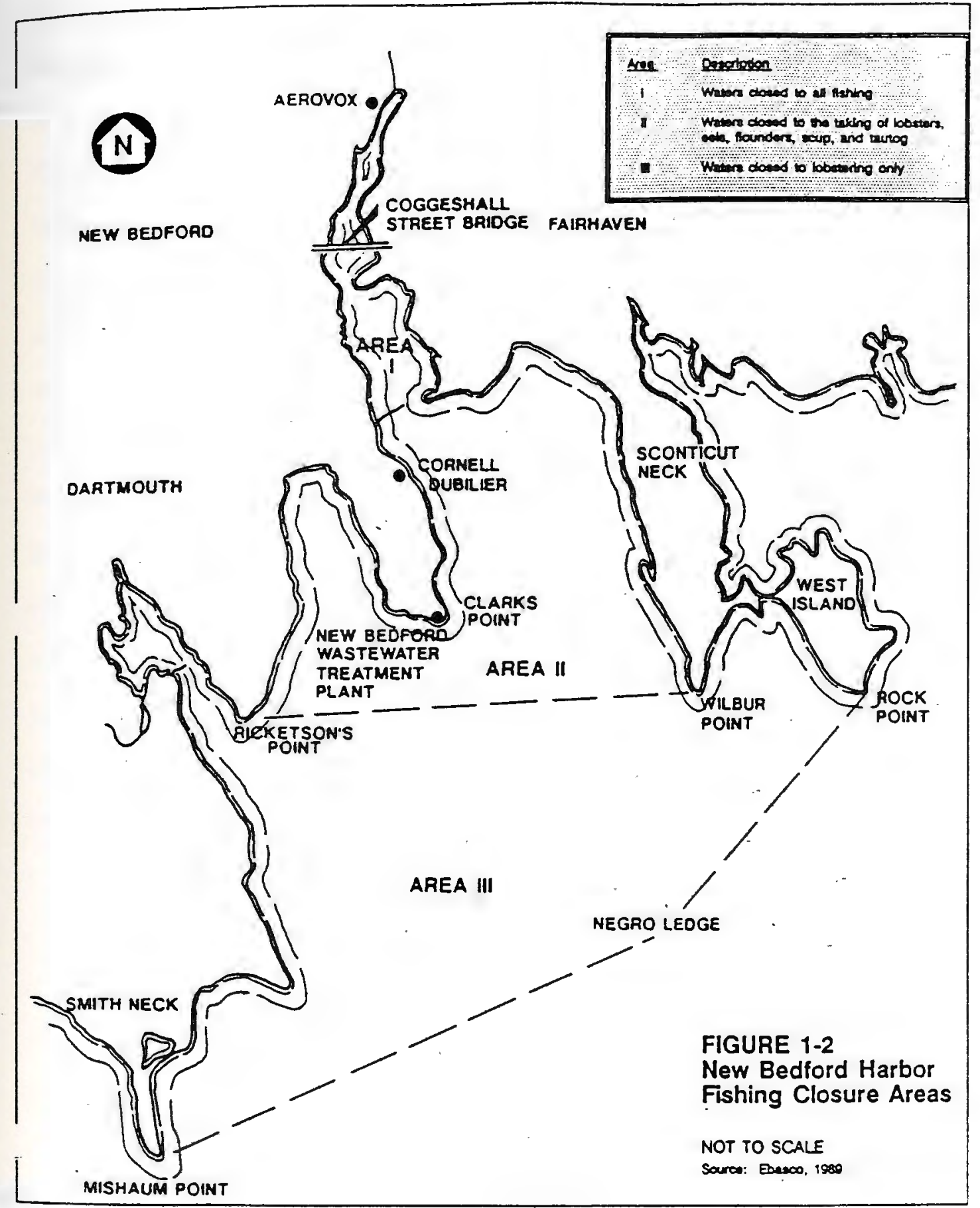

Figure I.2: Fishing Closure Areas.

Source: USEPA 1990b; $1992 \mathrm{~b}$. 
Another study estimated that property values within two miles of the contaminated waters had been reduced by a total of $\$ 26.2$ to $\$ 39$ million (Grigalunas and Opaluch, 1989). 


\section{B. 2. Sociodemographic characteristics.}

In an era which has seen the flight of "smokestack industry" from many of its former strongholds, contaminated marine sediments are just one of an array of difficulties faced by the towns adjoining the Acushnet River. New Bedford, in particular, is among the poorest municipalities in Massachusetts; demographic statistics present a picture of a metropolitan area which is disadvantaged in numerous ways.

According to the 1990 Census, the population of New Bedford totals 99,922, while Fair Haven and Acushnet have populations of 16,132 and 9,554, respectively (US Department of Commerce, 1992a). New Bedford's median household income in 1990 was $\$ 22,647$, just $61 \%$ of the state median; median household income in Fair Haven was $\$ 30,097$, or $81 \%$ of the state figure ${ }^{3}$. In 1990, 16.8\% of New Bedford residents lived below the official poverty level, nearly double the state average. Unemployment in that city was over $12 \%$, while less than half of residents over the age of 25 reported having finished high school, compared with the state-wide average of $80 \%$ (US Department of Commerce, 1993 and $1992 \mathrm{~b})$.

While New Bedford may be economically disadvantaged in comparison to the rest of Massachusetts, the area has

${ }^{3}$ Many of the census data which are available for New Bedford and Fair Haven do not exist for Acushnet, a much smaller municipality. 
traditionally represented a gateway to opportunity for one particular group: Portuguese immigrants. The New Bedford area has been a major center of immigration from Portugal since the mid-19th Century (Cardozo 1976). The Census does not separate the Portuguese from other European immigrants, nor does it class those of Portuguese descent as "Hispanic," so it is difficult to estimate the number of Portuguese immigrants and descendents in the New Bedford area. The importance of this ethnic group is suggested, however, by the fact that nearly $30 \%$ of New Bedford residents, according to the Census, speak Portuguese at home (US Department of Commerce, 1992b). Anecdotally, the Portuguese in New Bedford are overwhelmingly islanders: mostly Azorean, with a significant minority of Cape Verdeans, as well. Recent immigrants often work in the mills, in the fishing fleet, or in the construction industries.

The problem of coastal contamination is particularly relevant to a city such as New Bedford. The boarded-up mills remind us that the former economic development paradigm, successful though it once was, is obsolete. New Bedford's extensive, underutilized waterfront, historic architecture, and southeastern New England location would seem to suggest a potential for the development of tourism. It is obvious, however, that a harbor which is best known for its concentrations of toxins is unlikely to have the appeal necessary to provide the foundation for a burgeoning tourism industry. 


\section{C. The New Bedford Harbor superfund site.}

\section{C. 1. Superfund: History and overview.}

The Comprehensive Environmental Response, Compensation, and Liability Act of 1980 (CERCLA) ${ }^{3}$ created a comprehensive program to address the problem of hazardous waste sites

nationwide. As implemented in 1981, the program established the National Priorities List (NPL), a list of sites most in need of federal action, based on categorization under CERCLA's Hazard Ranking System (HRS). The law created the Superfund, a $\$ 1.6$ billion revolving fund, for use by USEPA to remediate NPL sites (Hird 1993; Johnston and Nixon 1992).

In 1986, CERCLA was significantly revised and expanded by the passage of the Superfund Amendments and Reauthorization Act of 1986 (SARA). This legislation increased the superfund to $\$ 8.5$ billion, detailed stricter site cleanup standards, and increased the role of the public in Superfund decisionmaking. While Superfund has maintained popularity with the public as well as with legislators, the program has been shown to be economically inefficient as well as socially inequitable. Superfund cleanup expenditures have been calculated as high as $\$ 77$ billion per statistical life saved for low-risk sites ${ }^{4}$, while the

${ }^{3}$ As amended by SARA, 42 U.S.C. Sections 9601 et seq.

4 To put this figure in perspective, highway improvements can save lives at a cost of $\$ 20,000$ to $\$ 50,000$ per statistical life; while an American court, looking at an individual's lifetime earnings in a wrongful death suit, might value a life 
ultimate economic effect of Superfund--in spite of the law's "polluter pays" intent--tends to be the redistribution of public wealth toward more affluent communities as well as to the new army of environmental professionals which the Act has spawned (Hird 1993; Environmental Law Institute 1988).

I. C. 2. Policy history of the New Bedford Harbor Superfund Site.

Elevated levels of PCBs in Buzzards Bay were discovered by Woods Hole Oceanographic Institution in 1973; in the late 1970's and early 1980's, field.studies by the state and Federal Governments exposed widespread contamination throughout the New Bedford Harbor area. The highest concentrations were in what has come to be known as the Hot Spot, a 5-acre area located in the upper Acushnet River by the site of the Aerovox, Inc., capacitor manufacturing facility. Sediment concentrations of PCBs in the Hot spot range from 4,000 - 200,000 ppm; toxic metals concentrations are as high as 4,000 ppm. In 1982 USEPA placed New Bedford Harbor on the National Priorities List (NPL); the Superfund Site now includes the Acushnet River, New Bedford Harbor, and portions of Buzzards Bay (Fig. I.3). It has since been divided into two "operable units" (OUs) in order to create sub-projects of manageable size.

at a million dollars or more (Lewis 1990). 


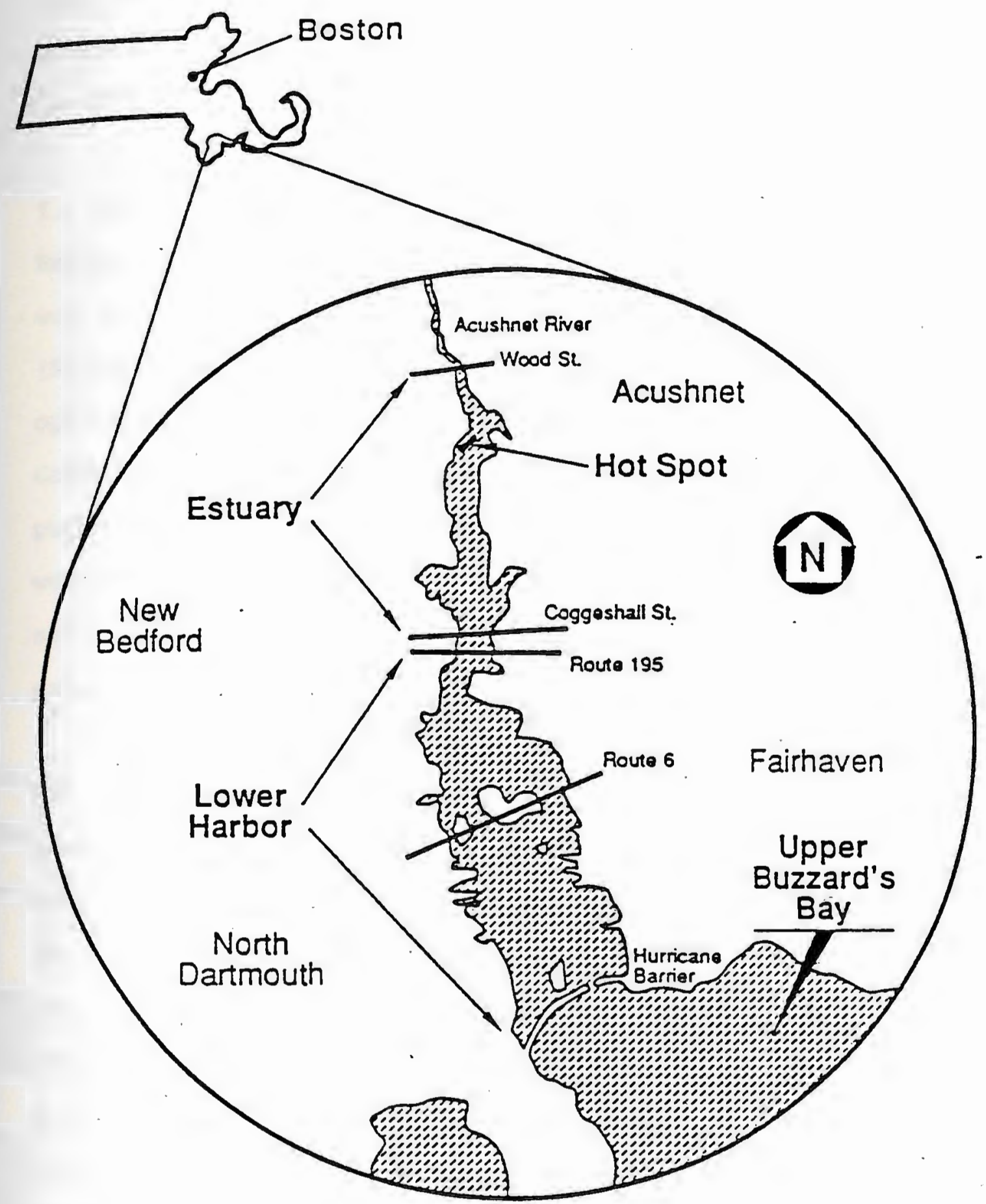

Figure I.3: The New Bedford Harbor superfund Site.

Source: USEPA $1989 a$. 
The Hot spot comprises the first OU, while less contaminated areas throughout the estuary, harbor, and upper bay comprise the second (USEPA 1989a; 1992a; 1992C) (Figs. I.4, I.5).

In 1983, the Division of Waste Management, USEPA Region I, published its first plan concerning the Site, the Remedial Action Master Plan (RAMP). Publication of the RAMP was followed by the Remedial Investigation/Feasibility Study (RI/FS) required by CERCLA, resulting in a set of clean-up options which USEPA presented to the public in 1984. Comments on the RAMP from other governmental entities, the public, and "potentially responsible parties" (PRPs) who would have to pay for it were skeptical of the project's ability to dredge contaminated sediments without exacerbating the problem by dispersing the contamination.

In response to such criticism, USEPA contracted with the US Army Corps of Engineers to conduct a full-scale dredging pilot study in the Acushnet. Yet another FS, along with a comprehensive risk assessment (RA), was completed in the late 1980's; from this emerged, in 1989, USEPA's second major remediation plan for the upper Acushnet, the Hot spot Proposed Plan (HSPP). This plan called for the dredging of 10,000 cubic yards (cy) of contaminated sediment from the Acushnet River, which would be "dewatered" in engineered shoreside basins, referred to by USEPA as confined disposal facilities, or CDFs. 


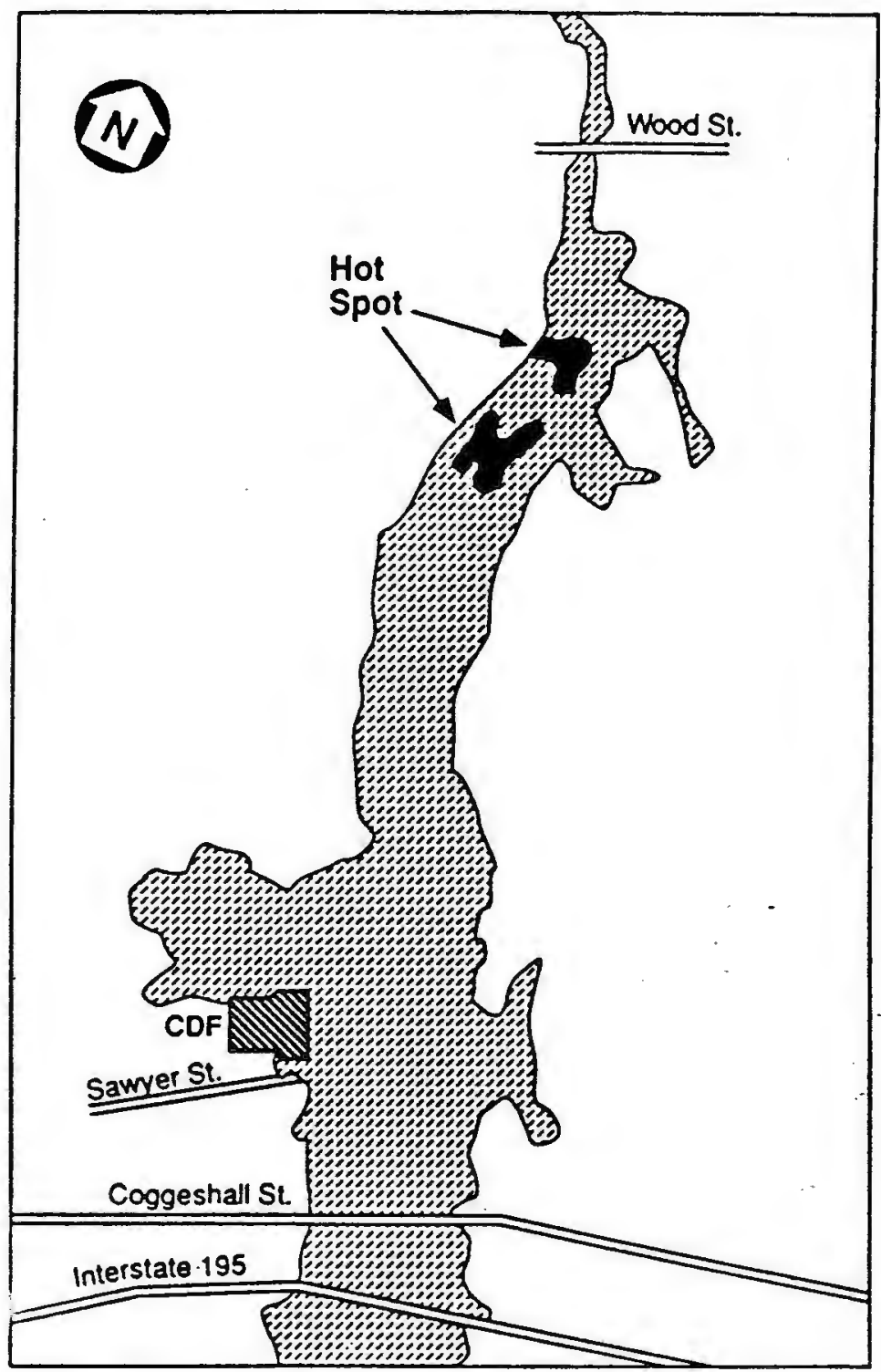

\section{Legend}

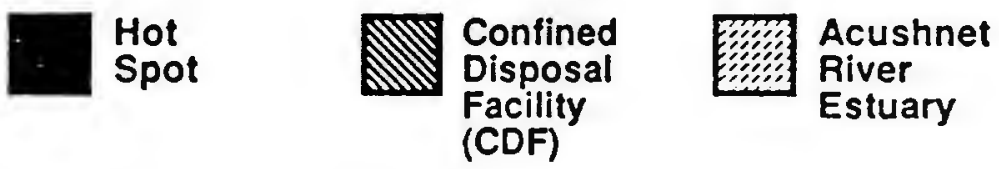

Figure I.4: Hot Spot Operable Unit.

Source: USEPA 1989 a 


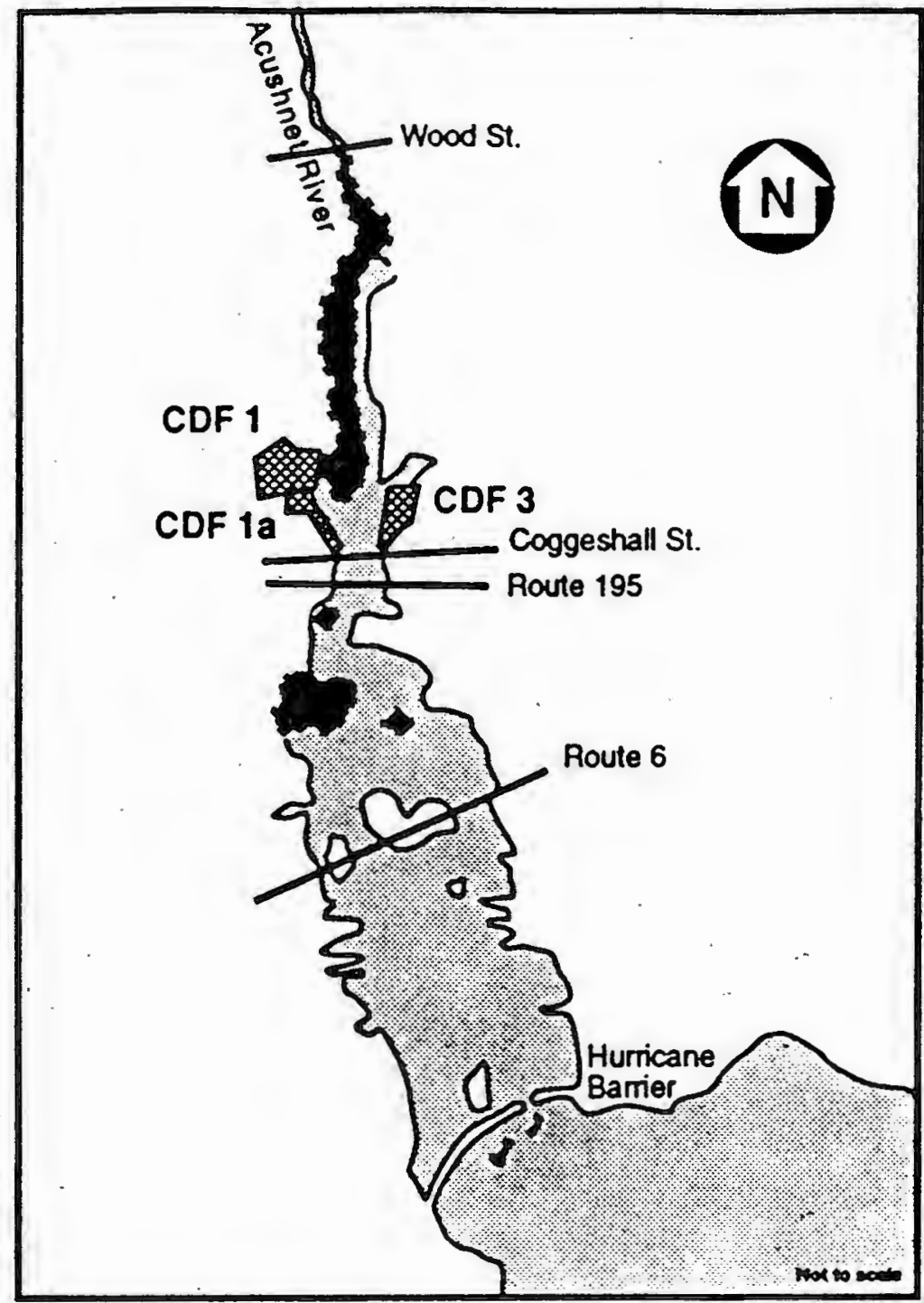

\section{Legend}

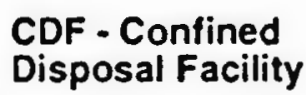

Areas to be dredged in estuary and lower harbor ( $>50 \mathrm{ppm}$ PCBs)

Figure I.5: Lower Harbor / Bay Operable Unit.

Source: USEPA $1992 a$. 
The decanted solids would then be incinerated in a hazardous waste incinerator ${ }^{5}$ temporararily assembled on the west bank of the Acushnet. The residual ash would be temporarily stored in the CDFs, solidified if necessary. The incinerator and CDFs would be located at the foot of Sawyer Street, in the North End of New Bedford, an area, like much of the city, of mills and tenements, largely residential. According to the Hot Spot Proposed Plan, once the Hot Spot sediments were dredged and incinerated, USEPA would move on to remediate the less highly contaminated areas of the Superfund Site (USEPA 1989a). The Hot Spot Proposed Plan was ratified by means of a Record of Decision (ROD) which USEPA published in April, 1990, formally selecting the dredging and incineration as the means of remediating the contamination of the upper Acushnet River (USEPA 1989b). In 1992, USEPA issued an "Explanation of Significant Differences" (ESD) which modified the ROD, stating that the incinerator ash would be permanently, rather than temporarily, stored in the shoreside CDFs at the foot of Sawyer Street (USEPA 1992b). Initially, the Hot Spot remediation process was expected to take one year and to cost approximately $\$ 14.3$ million (USEPA 1989a); this figure was revised to $\$ 16.1$ million several years later when the plan was modified by the ESD (USEPA 1992b; 1992C).

${ }^{5}$ Referred to, euphemistically, in the Hot spot Proposed Plan as a "thermal destruction facility." 
In 1983 and 1984, the US Department of Justice filed civil complaints against five of New Bedford's electrical parts manufacturers for recovery of clean-up costs and natural resource damages (Casner et al. 1990). The suits were settled by a series of consent decrees from 1990 to 1992, in which the five PRPs agreed to pay a total of $\$ 110$ million to USEPA. Of this amount, $\$ 84$ million would go toward the cleanup; $\$ 20$ million for restoration under CERCLA's natural resource damages provision (42 U.S.C. Section 9607 (f)(1)); and the difference to reimburse the State and Federal Government for costs incurred (Allen 1992a; Garmon 1993). 


\section{D. Public involvement in the New Bedford Harbor superfund site.}

The purpose of the Comprehensive Environmental Response, Compensation, and Liability Act (CERCLA) (42 U.S.C. 9601 et seq.) is to provide USEPA with the means to address sites contaminated by hazardous substances, and to broadly empower the Agency to recover costs from polluters for cleanup of such sites (Williams 1993; Johnson 1990). Within this framework, the Act seems to have an uneasy regard for public participation in superfund decisionmaking. It requires a degree of public involvement in USEPA's selection and implementation of CERCLA response ${ }^{6}$ plans, but is less than unequivocal regarding the relative importance of citizen input in the formulation of plans. CERCLA contains provisions for citizen suits, but such suits are subject to important jurisdictional limits. The courts have frequently been called upon to determine the specific nature of these limits - - and therefore the degree to which citizens have the right to challenge CERCLA response decisions. In most cases, Federal courts have held that CERCLA deprives them of jurisdiction to hear any challenge,

${ }^{6}$ While the language of CERCLA distinguishes between "removal" and "remediation" actions, such distinction is not germane to this study; therefore, I will use "response" to encompass both removal and remediation of hazardous wastes under CERCLA. 
by any party, to cleanup activities at a superfund site until such activities have been completed.

\section{D. 1. Statutory requirements.}

As amended, CERCLA requires USEPA to engage in a range of public involvement activity in the process of cleaning up a superfund site. The Agency is required to solicit public comments during the cleanup and to keep the public fully informed throughout the process. The Act authorizes the Agency to provide citizen's groups with Technical Assistance Grants (TAGs) of up to $\$ 50,000$. "to obtain technical assistance in interpreting information" regarding almost any aspect of a Superfund Site and its cleanup. Among other things, the TAGs are intended to "facilitate public participation in the selection of [a] remedial action at the facility" and to "facilitate public participation at all stages of a remedial action" (42 U.S.C. Sxn. 9617). The law requires USEPA to provide the public with "a reasonable opportunity to comment and provide information about [a] plan" and "an opportunity for a public meeting in the affected area." It requires that USEPA respond to public comments, but stops short of saying how much weight the Agency should give public comment within the total superfund calculus (42 U.S.C. $9613(\mathrm{k})$ ). Unlike the National Environmental Policy Act of 1968 (NEPA), CERCLA does not mandate public hearings per se. CERCLA expressly grants 
Federal district courts "exclusive jurisdiction over all controversies arising under this Act" (42 U.S.C. 9613 (b)).

\section{D. 2. Case law pertaining to public participation in} Superfund.

In the event that a group of citizens or environmentalists objects to a response decision by USEPA? that group would, conceptually, have three avenues of legal recourse. Before the decision had been finalized, the group might seek to intervene in a consent decree between USEPA and a polluter (potentially responsible party, or PRP, in the language of CERCLA). After the decision had been made, the group might seek judicial review of a Superfund Record of Decision (ROD) in an effort to obtain an injunction against implementation of the remediation action. Finally, the group might challenge the constitutionality of the statute itself. All of these approaches have been tried in Federal court, with varying results; ultimately, however, no group has succeeded in blocking, by legal means, the implementation of a superfund remediation decision.

${ }^{7}$ As has increasingly happened in recent years when USEPA has chosen to employ incineration to remediate contaminated soils. Arguably, CERCLA/SARA as written failed to foresee the subsequent proliferation of citizen suits seeking to block USEPA remediation plans. 


\section{D. 2. a. Intervention in superfund consent decrees.}

The Comprehensive Environmental Response, Compensation, and Liability Act of 1980 provides for intervention as a matter of right by "any person" who "claims an interest" in a Superfund action (42 U.S.C. $9613(i)$ ). In addition, Rule 24 of the Federal Rules of Civil Procedure provides for intervention of right (Rule $24(a)$ ) as well as permissive intervention (Rule 24 (b)) in cases before the district courts.

A much-cited case concerning the ability of citizens' groups and environmental organizations to intervene in superfund consent decrees deals directly with the New Bedford Harbor Superfund Site: In re Acushnet River and New Bedford Harbor ${ }^{8}$, (Acushnet IV). ${ }^{9}$ In Acushnet IV, the District of Massachusetts considered a motion entered by USEPA and a PRP (AVX, Inc., a New Bedford capacitor manufacturer) to file a $\$ 2$ million partial consent decree for injury to the natural resources of New Bedford Harbor. The National wildlife Federation (NWF) sought right of permissive intervention, in order to argue for greater

\section{${ }^{8} 722$ F.Supp. 888 (D.Mass. 1989).}

${ }^{9}$ Acushnet IV is one of eight cases of the same title concerning the New Bedford Harbor superfund Site, considered between 1987 and 1989 by Judge Young of the U.S. District Court for the District of Massachusetts. Of the eight, only Acushnet IV and VI bear directly or indirectly upon public participation; therefore, only these two will be discussed herein. 
damages than USEPA would receive under the proposed settlement.

In its opinion, the District Court cited United states postal System $v$. Brennan, ${ }^{10}$ to the effect that permissive intervention is largely at the discretion of the District court. It then turned to the requirements of Rule 24 (b), finding the foremost to be timeliness. Other considerations were: (1) the nature and extent of the intervenor's interest; (2) potential delay or prejudice to the rights of the original parties; (3) whether the applicant would benefit from the intervention; and (4) whether the intervenors would contribute to equitable adjudication of the suit. ${ }^{11}$

In spite of the three years which had elapsed between the filing of the suit and NWF's motion to intervene, the Court found the application timely. It pointed out that NWF had had every reason to believe that its interests were being represented by the sovereigns, until the proposed consent decree was announced. At that point, the court observed, the difference between "the measure of damages sought by the sovereigns as opposed to [that of] the Federation" created a new interest "substantial" enough to

\section{${ }^{10} 579$ F.2d 188 (2nd Cir. 1978).}

${ }^{11}$ Citing Brennan and New Orleans Public Service, Inc. V. United Gas Pipe Line, 732 F.2d 452, (5th Cir.) (en banc) cert. denied sub nom. Morial V. United Gas Pipe Line Co. 469 U.S.

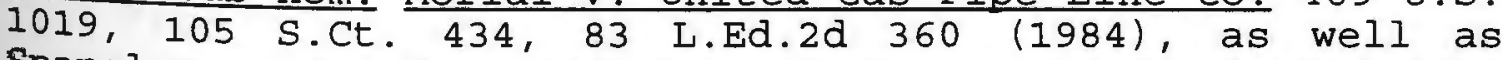
Spangler V. Pasadena City Bd. of Educ., 552 F.2d 1326 (9th Cir. 1977). 
justify intervention. The District Court's oft-cited rationale for this liberal interpretation of the timeliness requirement was that

[t]o do otherwise would promote a sort of prophylactic intervention whereby parties would be compelled to intervene in matters simply to protect their rights to participate in those matters...downstream... Such a result would obviously be expensive and inefficient. Permitting parties like the Federation to intervene keeps the number of parties in a dispute at a minimum unless and until a real divergence of interests arises.

The Court therefore allowed NWF to intervene.

A final settlement of $\$ 12.6$ million between USEPA, AVX, and one other PRP, Belleville, was approved by the District Court in 1991 over NWF's objections. The Federation brought appeal before the First Circuit in United States V. AVX Corporation $^{12}$, seeking to argue that the consent decree violated CERCLA's requirements. The court held that it could not consider such substantive issues because, in the wake of a settlement by the original parties, NWF's appeal was rendered moot by the Federation's inability to satisfy the prevenient issue of standing.

The First Circuit cited the US Supreme Court in Diamond v. Charles ${ }^{13}$ to demonstrate an appellant's need to show independent standing following settlement of a suit in district court. In Diamond, Justice Blackmun stated that "an intervenor's right to continue a suit in the absence of r

$$
\begin{aligned}
& { }^{12} 962 \text { F.2d } 108 \text { (1st Cir. 1992). } \\
& { }^{13} 476 \text { U.S. } 54,106 \text { S.Ct. 1697, } 90 \text { L.Ed.2d } 48 \text { (1986). }
\end{aligned}
$$


the party on whose side intervention was permitted is contingent upon a showing by the intervenor that he fulfills the requirements of Art. III." The appellate court then cited a number of other supreme Court cases in order to define such standing. Calling in particular upon Allen v. Wright, ${ }^{14}$ the Court observed that standing required a "distinct and palpable" injury which was "fairly traceable" to the alleged actions of the defendant.

The First Circuit pointed out that such injury could be aesthetic or environmental as well as physical or economic. ${ }^{15}$ But due to Article. III's limitation that the courts hear only "cases or controversies," the injury must be a factual one, "something more than an academic exercise in the conceivable" (citing SCRAP). The appellate court found that while "[t]here is no question that the interests which NWF seeks to protect are 'germane to the organization's purpose'"16 the Federation could not show the type of "'concrete injury'...needed to confer standing in an environmental suit". ${ }^{17}$ Rather, the court found NWF's claim that its "79,000 members and supporters in Massachusetts"

${ }^{14} 468$ U.S. 737,104 S.Ct. 3315, 82 L.Ed.2d 556 (1984).

${ }^{15}$ Citing the landmark environmental cases United States v. Students Challenging Regulatory Procedures (SCRAP), 412 U.S. 669,93 S.Ct. 2405,37 L.Ed.2d 254 (1973) and Sierra Club v. Morton, 405 U.S. 727, 92 S.Ct. 1361; 31 L.Ed.2d 636 (1972).

${ }^{16}$ Citing Hunt $v$. Washington State Apple Advertising Comm'n, 432 U.S. 33, 97 S.Ct. 2434, 53 L.Ed.2d 383 (1977).

${ }^{17}$ Citing, accord, Conservation Law Foundation of N.E. V. Reilly, 950 F.2d 38 (1st Cir. 1991). 
"have been and will continue to be harmed by [PCB] releases" in New Bedford Harbor inadequate. "NWF," it observed, "makes only the most nebulous allegations regarding its member's identities and their connection to the relevant geographic area...Gauzy generalities of this sort, unsubstantiated by any factual foundation, cannot survive [the original litigants'] motion to dismiss."

Like the Acushnet IV court, district and appellate courts nationwide have found timeliness to be the threshold consideration for intervention in CERCLA consent decrees ${ }^{18}$. With respect to Acushnet IV's second requirement, that the would-be intervenor show injury-in-fact, a number of subsequent opinions have used the precedent of New Orleans ublic Service, Inc. V. United Gas Pipe Line, supra, to distinguish between a mere "economic interest" and one which is "legally protectable," and thus adequate to establish the right to intervene. ${ }^{19}$

Once a party has shown that its request for intervention has satisfied the two requirements set forth in Acushnet IV, a court may review a superfund consent decree. In recent years, the dominant standard for such review has

${ }^{18}$ See, e.g., Bloomington v. Westinghouse Electric Corp., 824 F.2d 531, 17 E.L.R. 21185 (7th Cir. 1987); United States $\mathrm{y}$. Acton Corp. on behalf of Vikoa, 131 F.R.D. 431 (D.N.J. 1990); United States V. Bliss 132 F.R.D. 58 (E.D.Mo. 1990); United States V. BASF-Inmont Corp., 819 F.Supp. 601 (E.D. Mich. 1993).

${ }^{19}$ See, e.g. Acton and Bliss, op cit. note 12 , as well as United States V. ABC Industries, 153 F.R.D. 603 (W.D. Mich. 1993). 
been the three-prong test set forth by the Sixth Circuit in United States $v$. Azko Coatings of America. Inc. ${ }^{20}$ : that the consent decree be fair, reasonable, and consistent with the goals of CERCLA (Johnson 1993).

\section{D. 2. b. Challenges to remedial decisions.}

Like much Federal environmental legislation, CERCLA as amended by SARA contains express provision for citizen suits, assigning jurisdiction over such controversies to the district courts:

(a) AUTHORITY TO BRING CIVIL ACTIONS. -- Except as provided...in section $9613(\mathrm{~h})$... any person may commence a civil action on his own

behalf... against any person (including the United states...) who is alleged to be in violation of any standard, regulation, condition, requirement or order [made] pursuant to this chapter...or...against the President or...the Administrator of [USEPA]... where there is alleged a failure...to perform any act or duty under this chapter...

(c) RELIEF. -- The district court shall have jurisdiction...(42 U.S.C. 9659).

While a party could clearly make use of this provision to force USEPA to initiate action at a hazardous waste site ${ }^{21}$, it has proven to be of little use to groups wishing to contest Superfund remediation decisions. The principal reason for this is that CERCLA Section 9613 (h) has been held

${ }^{20} 949$ F.2d 1409, 22 E.L.R. 20405 (6th Cir. 1991).

${ }^{21}$ See. e.g., U.S.E.P.A. V. Environmental Waste Control, 917 F.2d 327 (7th Cir. 1990). 
to establish strict jurisdictional limits on challenges to USEPA's Superfund decision-making:

(h) TIMING OF REVIEW. -- No Federal court shall have jurisdiction under Federal law other than under section 1332 of title 28 of United States Code (relating to diversity of citizenship jurisdiction) or under state law...relating to cleanup standards...to review any challenges to removal or remedial action selected under section 9604 [removal and remedial actions]... in any action except one of the following...

(4) An action under section 9659 (relating to citizen suits) alleging that the removal or remedial action taken under section 9604 of this chapter or secured under section 9606 of this title was in violation of any requirement of this chapter. Such an action may not be brought with regard to a removal where a remedial action is to be undertaken at the site (42 U.S.C. 9613) (emphasis added).

Exception (4) to the jurisdictional bar of $9613(\mathrm{~h})$ has been a pivotal issue in CERCLA citizens' suits.

Specifically, controversy has adhered to the precise meaning of "removal," and the question of exactly what time limit is implied by the construction "is to be undertaken." The ambiguity of 42 U.S.C. $9613(\mathrm{~h})(4)$ has forced Federal courts to repeatedly revisit the legislative history of the CERCLA/SARA. Typically, courts have held that $9613(\mathrm{~h})$ bars any attempt to block or alter USEPA's Superfund cleanup decisions; that is, a remedial action cannot be challenged under the citizen suit provision until it has been completed. Moreover, this jurisdictional bar has generally been held to be comprehensive in scope, preventing not only direct challenges to USEPA remediation plans, but challenges to parts of plans, as well as suits brought under other 
environmental laws which might have bearing upon CERCLA actions. ${ }^{22}$

Once a court does review a ROD, the language of CERCLA limits judicial review to the administrative record:

(j) JUDICIAL REVIEW. --

(1) LIMITATION. -. . . any judicial action under this chapter...shall be limited to the administrative record...

(2) STANDARD. - - ...the court shall uphold [USEPA's] decision in selecting the response action unless the objecting party can demonstrate, on the administrative record, that the decision was arbitrary and capricious or otherwise not in accordance with the law (42 U.S.C. 9613).

Though no suit was ever brought under section 9613 regarding USEPA's plans at the New Bedford Harbor Superfund Site, the applicability of this standard to that case was verified by the District of Massachusetts in In re Acushnet River \& New Bedford Harbor: Proceedings re Alleged PCB Pollution $^{23}$ (Acushnet VI). Important precedents for the District Court in this instance were two suits brought by PRPs, in which district courts found only the "arbitrary and capricious" standard of review was appropriate to CERCLA challenges. ${ }^{24}$

${ }^{22}$ The exception of United States $\mathrm{v}$. State of Colorado, 990 F.2d 1565 (10th Cir. 1993), cert. denied 127 L.Ed.2d 216, 114 S.Ct. 922, infra, is notable, but arguably a special case. The outcome of Colorado hinged on the determination that a state has the right to enforce its own hazardous waste law (enacted, in this case, pursuant to RCRA) at a superfund site.

${ }^{23} 722$ F.Supp. 888 (D.Mass. 1989) .

${ }^{24}$ United States V. Seymour Recycling Corp., 679 F.Supp. 859 (S.D.Ind. 1987) and United States V. Rohm \& Haas Co., 669 F.Supp. 672 (D.N.J. 1987). 
The jurisdictional bar of CERCLA section $9613(\mathrm{~h})$ was written into the law with the 1986 SARA reauthorization. According to Williams (1993), it appears to be a codification by Congress of a decision reached by the District of New Jersey in Lone Pine Steering Committee v. U.S. E.P.A. ${ }^{25}$ In Lone Pine, a group of PRPs brought suit against USEPA, seeking to block a ROD relating to the closure of a landfill which had been placed on the National Priorities List (NPL) ${ }^{26}$ as a result of the illegal dumping there of hazardous wastes. ${ }^{27}$ The plaintiffs claimed that USEPA's closure plan was unnecessarily elaborate and wished to implement a cheaper one, which they argued no less adequate, in order to avoid potential liability under CERCLA for the more expensive plan. The District Court examined questions of jurisdiction and scope of review.

${ }^{25} 600$ F.Supp 1487 (D.N.J. 1985), affirmed 777 F.2d 882,23 Envt.Rep.Cas. 1568, 16 E.L.R. 20009, (3rd Cir.), cert. denied 476 U.S. 1115, 90 L.Ed.2d 654, 106 S.Ct. 1970, 25 Envt.Rep.Cas. 1744.

${ }^{26}$ Placement on the NPL is among the first steps toward cleanup of a hazardous waste site under CERCLA: see 42 U.S.C. Section 9605 .

${ }^{27}$ While the focus of this study is on public participation and citizen suits, and while the Sxn. 9613(h)(4) exception which most concerns us relates to citizen suits, there a good deal of precedential overlap between CERCLA challenges brought by citizens, PRPs, and state governments. Therefore, while this discussion will center upon citizen suits, relevant actions brought by other types of parties must be mentioned, as well. 
Citing the US Supreme Court in Block V. Community Hutrition Institute, ${ }^{28}$ the Court noted that the extent to which a statute precluded judicial review was determined not only by the language of the law, but by its structure and nature, as well as its legislative history. Delving into CERCLA's history as well as the law's intent, the District Court concluded that

both the legislative history and the language of CERCLA suggest that to allow judicial review of a ROD by an entity which may (or may not) be the subject of a subsequent recovery action would frustrate Congress' intent to provide a mechanism whereby hazardous sites can be neutralized expeditiously.

Moreover, the Court found, some of the events of this particular case were "suggestive of the bog into which courts would descend if CERCLA were interpreted to permit [PRPs] to obtain judicial review of the issuance of a ROD." The Court also considered the limited precedent which had developed following the passage of the 1982 law, citing opinions which had found that courts lacked jurisdiction to review PRP claims brought to enjoin Superfund cleanup activities. ${ }^{29}$ Conversely, the Court considered and disagreed with $\underline{J} . \mathrm{V}$. Peters V. Ruckelshaus, ${ }^{30}$ wherein the Northern District of Ohio had held that PRPs did indeed have

${ }^{28} 467$ U.S. 340, 104 S.Ct. 2450, 81 L.Ed.2d 270 (1984).

${ }^{29}$ United States V. Outboard Marine Corp., 104 F.Supp. 405 (N.D.Ill. 1984) and Aminoil v. United States Environmental Protection Agency, 599 F.Supp. 69 (D.Calif. 1984).

${ }^{30} 584$ F.Supp. 1005 (N.D.Ohio, 1984), affirmed 767 F.2d 263 (6th Cir. 1985). 
the right to obtain judicial review of a Superfund ROD. The peters court had ruled the issuance of a ROD by USEPA a "final administrative action" subject to judicial review under CERCLA; moreover it found the PRPs' potential liability for the clean-up to comprise the "actual or threatened injury" required to establish standing under Article III. ${ }^{31}$ The reasoning which the Lone Pine court relied upon to reject the precedent of peters has become a fundamental justification for denying PRPs review of USEPA RODs: that the PRPs will have the opportunity to state their case in the subsequent CERCLA cost recovery suit, and that therefore the ROD is not in and of itself "a final agency action." In the words of the Court:

[There is] no reason why plaintiffs cannot raise as a defense in a cost recovery action every objection to the ROD which they could legitimately raise in a judicial proceeding at this time.

The plaintiffs' motion was accordingly dismissed for lack of jurisdiction.

It is important to note that the reasoning which the District Court employed in Lone Pine would not fully apply to citizens' suits, since unlike PRPs, citizens do not have the subsequent opportunity to state their case in a cost recovery suit, and because monetary damages are fundamentally different from claims of health impacts. The

${ }^{31}$ Ultimately, however, the Peters court dismissed the PRPs' suit for failure to state an actionable claim. 
Lone Pine court acknowledged as much when it stated, dictum,

that

the statute may contemplate a different rule of judicial review in the case of a victim of a hazardous waste site. The statute is designed particularly to protect such persons and, unlike the persons responsible for the hazardous waste, no specific provision is contained in the statute under which they can obtain judicial review... In any event, it is unnecessary to resolve that question now.

In codifying the decision of the Lone pine court by means of CERCLA Section $9613(\mathrm{~h})$ in the SARA reauthorization, Congress did nothing to clear up the ambiguity which the court had alluded to. Since the passage of SARA, therefore, courts have been forced to grapple with the meaning of section 9613 and its applicability to citizens' suits. ${ }^{32}$

Two Federal cases heard soon after the passage of SARA have become important precedents regarding this question, although each took an opposite view of the issue: Cabot Corp. V. United States Environmental Protection Agency ${ }^{33}$ and Alabama v. United States Environmental Protection Agency. ${ }^{34}$

In Cabot, PRPs attempting to block a CERCLA ROD sued as citizens. The PRPs argued that under the 42 U.S.C. $9613(\mathrm{~h})(4)$ exception, citizens' suits were eligible for pre-

${ }^{32}$ The Third Circuit, in U.S. V. Princeton Gamma-Tech, Inc., 31 F.3d 138 (3rd. Cir. 1994), called the legislative history of $9613(\mathrm{~h})(4)$ "confusing" and the citizens' suit provision "a troublesome one."

${ }^{33} 677$ F.Supp. 823, 18 E.L.R. 20835 (E.D.Pa. 1988).

${ }^{34} 871$ F.2d 1548, 19 E.L.R. 20956 (11th Cir. 1989) cert. denied 493 U.S. 991, 107 L.Ed.2d 535, 110 S.Ct. 538, appeal after remand 925 F.2d 385, 21 E.L.R. 21026 (Ilth Cir). 
enforcement review. The Court examined the language and legislative history of CERCLA in order to evaluate the claim. While deciding that the PRPs were ineligible to masquerade as citizens for the purpose of employing the exception, the Court did find, dictum, that some of the legislative history of CERCLA/SARA "emphasized the distinction between suits focusing on health or environmental concerns and suits alleging monetary harm" in terms of judicial review. Therefore, the District court concluded, in the case of a true citizens' suit, section $9613(\mathrm{~h})(4)$ "arguably permits challenges to EPA's plans even before they have been implemented." The dictum of the Cabot court has been used by citizens as well as PRPs in subsequent cases to argue for judicial review of Superfund response actions, in each case without success. ${ }^{35}$

The Cabot court rejected, as well, PRPs' claim that the ROD was separable from "removal or remedial action" within the context of CERCLA. The idea that each individual aspect of a CERCLA response action is, in and of itself, a "removal or remedial action," protected by the section $9613(\mathrm{~h})$ jurisdictional bar, has proven to be most significant to the

${ }^{35}$ See, e.g., Neighborhood Toxic Cleanup Emergency V. Reilly, 716 F.Supp. 828, 19 E.L.R. 21165 (D.N.J. 1989); U.S. v. Princeton Gamma-Tech, 31 F.3d 138 (3rd Cir. 1994); and Hanford Downwinders V. Dowdle, 841 F.Supp. 1050 (E.D.Wash. 1993). 
case law of CERCLA, and has been shared by many courts which have examined the Act. ${ }^{36}$

In Alabama $v$. United States Environmental Protection Agency, ${ }^{37}$ the Eleventh Circuit came to a very different conclusion than did cabot regarding the eligibility of citizens' suits for judicial review. In this instance, officials of the state of Alabama brought suit as private citizens to enjoin shipment of hazardous wastes from a Fuperfund Site in Texas to a treatment facility in Alabama. The District Court had granted a preliminary injunction and USEPA appealed, with Texas intervening.

Inter alia, the court considered the plaintiffs' claim that they were entitled to more meaningful involvement in USEPA's decision-making than they had been allowed. The plaintiffs argued that two statutes established Federal jurisdiction to compel compliance with CERCLA: (1) under CERCLA, the Section 9659 citizens' suit provision and the Section 9613 granting of jurisdiction to the district courts; and (2) the Administrative Procedures Act (APA), 5

${ }^{36}$ E.g. Cooper Industries, Inc. V. United States EPA, 775 F.Supp. 1027, 34 Envt.Rep.Cas. 1290, 22 E.L.R. 20608 (W.D.Mich. 1991); Environmental Waste Control, Inc. V. Agency for Toxic Substances and Disease Registry, 763 F. Supp 1576, 33 Envt.Rep.Cas. 1297, 21 E.L.R. 21380 (N.D.Ga. 1991); North Shore Gas V. EPA 930 F.2d 1239, 32 Envt.Rep.Cas. 2049, 21 E.L.R. 21038 (7th Cir. 1991); and In re Hanford Nuclear Reservation Litigation, 780 F.Supp. 1551, 34 Envt.Rep.Cas. 1145, 22 E.L.R. 20703 (E.D.Wash. 1991).

${ }^{37} 871$ F.2d 1548, 19 E.L.R. 20956 (11th Cir. 1989) cert. denied 493 U.S. 991,107 L.Ed.2d 535, 110 S.Ct. 538, appeal after remand $925 \mathrm{~F} .2 \mathrm{~d} 385,21$ E.L.R. 21026 (11th Cir.). 
U.S.C. Section 701 et seg., which provides, inter alia, that a "person suffering legal wrong... or adversely affected or aggrieved by agency action... is entitled to judicial review."

The Alabama court first examined the language of 42 U.S.C. $9613(\mathrm{~h})(4)$, allowing for judicial review of citizens' actions only after a remedial action has been "taken" or "secured." It cited the U.S. Supreme Court in Consumer Product Safety Commission V. GTE Sylvania, Inc., ${ }^{38}$ to the effect that the language of a statute is conclusive "[a]bsent clear legislative intent to the contrary;" based on the plain language of section $9613(h)(4)$, the court found the statute to require that the remedial action be complete before a case might be heard.

Turning next to the CERCLA's legislative history, the Eleventh Circuit, unlike the Cabot court, found it supportive of the idea that the statute barred judicial review of citizen suits until the campletion of a CERCLA mesponse action. In light of the delay which inevitably ttends lawsuits, the Court emphasized the importance of its observation that "the primary purpose of CERCLA is the prompt cleanup of hazardous waste sites." The Alabama court acknowledged Cabot but emphasized the precedent of Lone Pine, finding that both the language and intent of CERCLA barred precompletion judicial review of superfund cleanup

${ }^{38} 447$ U.S. 102,100 S.Ct. 2051, 64 L.Ed.2d 766 (1980). 
actions. It rejected the plaintiffs' argument that the ROD was an action "taken" within the meaning of CERCLA, thus eligible for challenge under the $9613(\mathrm{~h})(4)$ exception; moreover, based on CERCLA's legislative history, the court found that the broad jurisdictional bar of section 9613 applied equally to the plaintiffs' APA claim.

The Eleventh Circuit, therefore, reversed the finding of the District Court and dismissed the case for lack of subject-matter jurisdiction. The Alabama decision, denied eertiorari by the supreme Court, has probably been the single most important precedent in the subsequent development of CERCLA/SARA case law. It used case law dealing with PRP claims to apply CERCLA's jurisdictional bar to true citizen suits, thus extending the scope of the $9613(\mathrm{~h})(4)$ prohibition.

The emphasis of the Alabama opinion on CERCLA's prioritization of an expeditious clean-up, as well as its finding that a remedial action must have been completed before it may be reviewed, has been used by numerous courts to rebuff plaintiffs' attempts to challenge superfund remediation decisions. ${ }^{39}$ Not all courts which have examined

${ }^{39}$ See, e.g., Schalk V. Reilly, 900 F.2d 1091, 20 E.L.R. 20669 , reh. den., en banc, (7th Cir. 1990) cert. denied Frey V. Reilly, 498 U.S. 981, 112 L.Ed.2d 521, 111 S.Ct. 509, reh. den. 498 U.S. 1074,112 L.Ed.2d 863, 111 S.Ct. 802 ; In re Hanford Nuclear Reservation Litigation, 780 F.Supp. 1551, 34 Envt.Rep.Cas. 1145, 22 E.L.R. 20703 (E.D.Wash. 1991); Arkansas Peace Center V. Dept. Of Pollution Control, 999 F.2d. 1212 (8th Cir. 1993) cert. denied 128 L.Ed.2d 70, 114 S.Ct. 1397, 62 U.S.I.W. 3657 ; Hanford Downwinders V. Dowdle, 841 F. Supp. 1050 (E.D.Wash. 1993). 
its precedent, however, have been as comfortable that the language and legislative history of section 9613 precluded citizen challenges to remedial actions. ${ }^{40}$

Just a year after it denied the Eleventh Circuit's Alabama decision certiorari, the supreme Court denied certiorari of a similar decision by the seventh circuit in Ghalk v. Reilly. ${ }^{41}$ This case concerned suits brought by local residents seeking to prevent USEPA from incinerating FCB-contaminated wastes as part of a Superfund cleanup in Bloomington, Indiana. The District Court had dismissed the cases separately, finding that. they sought the type of preenforcement review barred by CERCLA; the Court of Appeals heard a consolidated appeal. As in Lone Pine, supra, the plaintiffs in Schalk claimed that USEPA had, inter alia, violated NEPA, 42 U.S.C. 4321 et seq., by selecting incineration as a remedy without adequate public hearings or an Environmental Impact statement (EIS). They argued that, in challenging the consent decree wherein USEPA chose the contested remedy, they were challenging an "action taken"

E

${ }^{40}$ In U.S. V. Princeton Gamma-Tech, 31 F.3d 138 (3rd Cir. 1994), the Third Circuit stated, dictum, that a district court might be able to grant an injunction under 42 U.S.C. $9613(\mathrm{~h})(4)$ where citizens could show an imminent threat of "irreparable harm to public health or the environment. C.f. Arkansas Peace Center v. Dept. of Pollution Control, op cit. note 3 and Neighborhood Toxic Cleanup Emergency v. Reilly, 716 F.Supp. 828, 19 E.L.R. 21165 (D.N.J. 1989).

${ }^{41} 900$ F.2d 1091, 20 E.L.R. 20669, reh. den., en banc, (7th Cir. 1990) cert. denied Frey V. Reilly, 498 U.S. 981, 112 L.Ed.2d 521, 111 S.Ct. 509, reh. den. 498 U.S. 1074,112 L.Ed.2d 863, 111 S.Ct. 802 . 
within the meaning of CERCLA; thus theirs was a postenforcement challenge, to which the District Court had improperly applied the section $9613(\mathrm{~h})$ denial of preenforcement review.

The Court of Appeals did not agree. Relying on the plain language of CERCLA, the Seventh Circuit found that "[t]he obvious meaning of this statute is that when a remedy has been selected, no challenge to the cleanup may occur prior to completion of the remedy." The Court leaned heavily upon the precedent of Alabama to bolster its argument; since its decision was based primarily upon the language of the statute, it made only the most cursory examination of SARA's legislative history. It dismissed the plaintiffs due process claims with little more than a wave of the hand, and affirmed the decisions of the District court.

Subsequent decisions regarding CERCLA's citizen-suit provisions have been generally consistent with the opinions of Alabama and Schalk, finding that 42 U.S.C. $9613(\mathrm{~h})(4)$ expressly bars judicial review of a superfund clean-up until such action has been completed. ${ }^{42}$ As recently as 1993, however, an Arkansas district court came to the opposite

\footnotetext{
${ }^{42}$ E.g. In re Hanford Nuclear Reservation Litigation, $O p$ Cit.; Reynolds V. Lujan, 785 F.Supp. 152 (D.N.M. 1992); Redland Soccer Club V. Dept. of Army, 801 F.Supp. 1432 (M.D.Pa. 1992); Heart of America Northwest $v$. West inghouse Hanford, 820 F.Supp. 1265 (E.D.Wash. 1993). A notable recent exception is U.S. V. Princeton Gamma-Tech, 31 F.3d 138 (3rd Cir. 1994): see note 34 .
} 
conclusion in a case involving a superfund clean-up quite similar to that of New Bedford. Overruled by an appellate decision which was, like Alabama and Schalk, denied certiorari by the Supreme Court, Arkansas Peace Center v. Dept. Of Pollution Control ${ }^{43}$ stands as yet another statement of the federal courts' unwillingness to review USEPA's Superfund remediation decisions.

In Arkansas Peace Center, a citizens' group attempted to take advantage of the Colorado precedent by using a RCRA clajm to block the incineration of dioxin-contaminated waste at the controversial Vertac incinerator in Arkansas. The subject of their action was a USEPA ROD which chose incineration as the selected remedy for some 28,000 drums, containing two types of dioxin, at an abandoned herbicide and pesticide plant.

The group had brought suit in Federal District Court, alleging inter alia that USEPA was in violation of RCRA, 42 U.S.C. 6901 et seg., insofar as it had failed to demonstrate that its incinerator would meet its own standard for dioxin removal efficiency. ${ }^{44}$ The District Court stated that it had jurisdiction to consider no more than defendants' compliance with USEPA's regulations; in so doing, however, the Court

${ }^{43} 999$ F.2d. 1212 (8th Cir. 1993) cert. denied 128 L.Ed.2d 70, 114 S.Ct. 1397,62 U.S.I.W. 3657.

${ }^{44}$ The so-called "six nines" requirement, 40 C.F.R. 264.343 (a) (2), which mandates that certain hazardous waste incinerators must achieve a destruction and removal efficiency (DRE) of $99.9999 \%$. 
found that a violation had occurred. Given a probability that the plaintiff would succeed on the merits, and that "a violation of regulations tips the scale heavily toward a determination that potential irreparable harm to plaintiffs outweighs the potential harm to defendants," the District court granted a preliminary injunction to prevent incineration of the wastes. Defendants appealed.

The Eighth Circuit ruled that the District Court had lacked subject-matter jurisdiction to grant injunction, basing its determination on the plain language of CERCLA as well as the now-considerable citizen-suit case law. The Court of Appeals cited Alabama to support its judgement that citizens' suits were barred until the completion of a CERCLA cesponse action, and Schalk to the effect that challenges to the response based on other environmental laws would result in the same delays that Congress sought to prevent as would challenges based on CERCLA itself. The Court considered plaintiffs' example of Colorado, but. found that CERCLA's explicit protection of states' rights to enforce their own environmental laws distinguished it from the case at bar. The Court of Appeals, therefore, reversed the District Court's granting of preliminary injunction, and remanded the case.

Unlike many similar sites, New Bedford Harbor was never the subject of a citizen suit. Had the citizens who objected to USEPA's ROD attempted to use CERCLA's citizen suit provisions to block the incineration, case law 
demonstrates that they probably would have failed as a result of the $9613(\mathrm{~h})$ jurisdictional bar. Some district courts have clearly been uncomfortable with this bar, but they have been reigned in by courts of appeals, whose decisions, in turn, have been denied certiorari by the US fupreme Court. CERCLA's citizen-suit provisions, as interpreted by the judiciary, appear to offer scant recourse for citizens who would contest a USEPA Superfund remediation decision.

\section{D. 2. C. Constitutional challenges to CERCLA.}

Throughout the case law of CERCLA, citizens' groups and PRPs seeking to contest CERCLA response actions have argued that the Constitutional right to due process is superior to the jurisdictional bar of 42 U.S.C. Section $9613(\mathrm{~h}) .{ }^{45}$ Generally speaking, however, courts which have specifically considered this issue have held that the section's denial of pre-enforcement judicial review encompasses Constitutional claims. In Lone Pine Steering Committee V. U.S.E.P.A., supra, and Neighborhood Toxic Emergency V. Reilly, supra, for example, district courts stated explicitly that the jurisdictional bar of 42 U.S.C. $9613(\mathrm{~h})$ prevented them from

${ }^{45}$ See, e.g., J.V. Peters V. Ruckelshaus, 584 F.Supp. 1005 (N.D.Ohio, E.D.1984); U.S. V. Seymour Recycling Corp., 679 F.Supp. 859 (S.D. Ind. 1987); Lone Pine Steering Committee V. U.S.E.P.A, supra; Alabama v. United States Environmental Protection Agency, supra; and Neighborhood Toxic Emergency v. Reilly, supra. 
hearing Constitutional claims related to ongoing CERCLA cleanups.

In 1991, however, the First Circuit allowed a Constitutional claim to stand in a CERCLA case: Reardon V. U.S. ${ }^{46}$ Reardon concerned a hazardous waste site to which USEPA had attached a lien in order to recover response costs, in accordance with 42 U.S.C. 9607, CERCLA's section on "Liability." Reardon, landowner and PRP, brought suit in District Court to argue that the lien should be removed from the property. Two of the plaintiff's three claims specifically contested USEPA's. application of CERCLA's lien provision to Reardon's property; the third "asserted that EPA's imposition of the lien without a hearing violated the due process clause of the Fifth Amendment to the United States Constitution."

The District Court found that CERCLA's limitation of judicial review, 42 U.S.C. $9613(\mathrm{~h})$, divested it of jurisdiction to hear the plaintiff's statutory claims. Considering the Constitutional claim, the Court stated that, while Section 9613 (h) purported to deny jurisdiction here, as well, Congress in fact lacked such power. However, finding that the lien under consideration "did not amount to a taking of a 'significant property interest' protected by the due process clause," the District Court dismissed the plaintiff's complaint.

${ }^{46} 947$ F.2d 1509, 34 Envt.Rep.Cas. 1070, 22 E.L.R. 20292 (1st Cir. 1991). 
Reardon appealed, and the First Circuit, finding that section $9613(\mathrm{~h})$ permitted the statutory challenges to the imposition of the lien, reversed the District Court's decision without reaching the Constitutional question. USEPA petitioned for rehearing and the First Circuit, en banc, considered the Constitutional issue.

on rehearing, the appellate court agreed with the District Court that the filing of the lien was the type of "enforcement activity" which was protected by the jurisdictional bar of 42 U.S.C. $9613(\mathrm{~h})$. Examining the language and legislative history of CERCLA/SARA, the court developed its argument in much the same way as had other courts which rejected challenges to CERCLA response activities.

However, the First Circuit's reading of the language of Section $9613(\mathrm{~h})$ led it to conclude that the section's jurisdictional bar, in referring to "removal or remedial actions selected under section $9604, "$ applied only to challenges concerning USEPA's administration of the statute, not the statute itself. The court cited the US Supreme Court to the effect that "where Congress intends to preclude judicial review of constitutional claims its intent to do so must be clear," 47 but found no such clear intent within the language of CERCLA/SARA. It rejected the reasoning of two

${ }^{47}$ Citing Webster V. Doe, 486 U.S. 592, 108 S.Ct. 2047,100

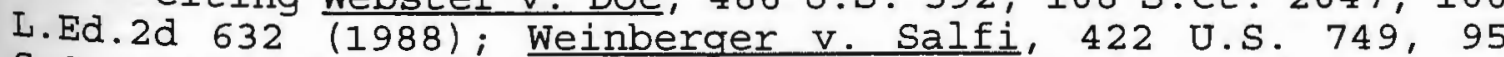
S.Ct. 2457, 45 L.Ed.2d 522 (1975); and Johnson V. Robinson, 415 U.S. 361,94 S.Ct. 1160, 39 L.Ed.2d 389 (1974). 
earlier cases which had found that $9613(\mathrm{~h})$ did indeed preclude all Constitutional challenges to CERCLA response actions, ${ }^{48}$ because they did not distinguish between "challenges to EPA's administration of CERCLA, and challenges to CERCLA itself." The Court considered Lone Pine, supra, as well, but observed that that case did not rule on the plaintiff's Constitutional claim.

The First Circuit also examined CERCLA/SARA's legislative history, finding no clear evidence of Congressional intent to bar Constitutional claims against CERCLA. It cited a case concerning immigration law, McNary v. Haitian Refugee Center, ${ }^{49}$ in which the supreme Court distinguished between administration of a statute and Constitutional claims against the statute itself with respect to a similar statutory jurisdictional bar.

Finding that 42 U.S.C. $9613(\mathrm{~h})$ could not preclude judicial review of Constitutional challenges to CERCLA itself, the First Circuit went on to. consider Reardon's due process claim, finding further that CERCLA's lien provisions had deprived Reardon of a "significant property interest" without due process of law. A majority of the First Circuit panel, therefore, reversed and remanded the constitutional portion of the suit. Circuit Judge Cyr authored a

${ }^{48}$ Barmet Aluminum V. Reilly, 927 F.2d 289 (6th Cir. 1991) and South Macomb Disposal Authority V. U.S.E.P.A., 681 F.Supp. 1244 (E.D.Mich. 1988).

$$
{ }^{49} 498 \text { U.S. } 479,111 \text { S.Ct. } 888,112 \text { L.Ed.2d } 1005 \text { (1991). }
$$


dissenting opinion, disagreeing not with the majority's conclusion that 42 U.S.C. $9613(\mathrm{~h})$ barred Constitutional challenges to CERCLA, but that due process had been denied in this particular instance.

\section{D. 2. d. Case law: Conclusion.}

The history of citizen challenges to CERCLA response actions and the "Timing of Review" provision (42 U.S.C. $9613(h)$ ) demonstrates that the statute has been created as much by the courts as by Congress. Faced with ambiguous statutory language, courts have been forced to consider every conceivable permutation of the citizen challenge to a CERCLA cleanup, and to rely heavily upon a legislative history which is not without internal contradictions. Eight years after the passage of the SARA reauthorization, CERCLA case law remains in flux, particularly in the First Circuit.

The weight of case law at this point clearly favors the conclusion that pre-completion challenges to USEPA's administration of CERCLA cleanups are barred by $9613(\mathrm{~h})$. However, the First Circuit's finding in Reardon, supra, suggests that a Massachusetts citizens' group which was able to craft the perfect challenge to CERCLA's constitutionality might find a yet-unexploited avenue of legal recourse. Given the number of NPL sites in the Nation and the controversy which currently attends some of USEPA's preferred response methods, it seems certain that citizens' groups will continue thread their way through the tortuous 
case law of CERCLA's citizens-suit provision and jurisdictional bar, in an effort to influence USEPA response decisions at CERCLA sites.

This observation has two implications for the study at hand. First, that the public participation provisions of CERCLA are in need of revision. Congress must clarify the statute's intent and provide for a medium of public/governmental communication which is more costeffective than the federal courts. Second, that if USEPA can avert legal challenges to its CERCLA response decisions by involving the public--as ultimately took place in New Bedford, by means of ODR's facilitated discussions--the benefits to public and agency alike might be substantial.

\section{D. 3. Prospective changes in CERCLA's public participation requirements.}

In October, 1994, leaders of Congress and the Clinton Administration were forced by congressional Republicans to abandon a major, year-long effort to rewrite the Comprehensive Environmental Response, Compensation, and Liability Act. While the Administration and Democratic leaders insisted that the legislation would be revived in 1995, just what shape the reauthorization might then take remains uncertain (Cushman 1995).

During 1994, committees in both the House and Senate worked at revisions to CERCLA/SARA which would have significantly expanded public participation in superfund. 
The House version, titled the Superfund Reform Act of 1994 (H. 3800), called for increasing the uses to which TAGs might be put and specified much more comprehensive public notification and involvement. It would require public meetings at every major step of a Superfund cleanup as well as the formation of state Citizen Information and Access offices to inform residents of the Superfund sites in their neighborhoods (US House of Representatives, 1994). But perhaps the most fundamental way in which the House bill would have changed the public participation section of the Superfund statute lay in the bill's explicit requirement that USEPA seek out and take into account the sentiments of local residents regarding a superfund remediation: SEC. 101. PUBLIC PARTICIPATION

(f) (3). To the extent practicable... [USEPA] shall solicit and evaluate concerns, interests, and information from the community likely [to be] affected by the facility...

(f) (4). During the remedial investigation and feasibility study, [USEPA] shall solicit the views and preferences of the affected community on the remediation and disposition of hazardous substances, pollutants, or contaminants at the facility. [These] views and preferences...shall be...considered in the screening of remedial alternatives for the facility.

This bi-directional information flow was emphasized within the revision's public meeting requirements, as well:

(f) (1) (B) Public meetings shall be designed to obtain information from the community and disseminate information to the community concerning [USEPA's] facility activities and pending decisions. (US House of Representatives, 1994). 
While the Senate bill, S. 1834, did not elaborate upon public participation in Superfund to the extent that the House bill did, its effect would have been substantially the same. Like the House version, it would have required USEPA to employ frequent public meetings and would have established Citizen Information and Access Offices. Also like the House version, and in contrast to current law, $S$. 1834 would have required USEPA to consider the local community's views regarding the remediation of a superfund site:

TITLE I - COMMUNITY PARTICIPATION AND HUMAN HEALTH SEC. 101. PURPOSES AND ACTIVITIES

(f) EARLY, DIRECT AND MEANINGFUL COMMUNITY INVOLVEMENT... [USEPA] shall consider the views, preferences and recommendations of the affected community regarding all aspects of the response activities...

(h) PROCESS FOR INVOLVEMENT.- As early as practicable after site discovery, [USEPA] shall provide regular, direct and meaningful community involvement in all phases of response activities at the facility...

(2)...The community's views and preferences shall be...considered in the development of remedial alternatives for the facility (US Senate 1994).

Like H. 3800 , S. 1834 would have expanded the uses to which the TAG grants could be put; one such use might be to "facilitate public participation in the selection of remedial action at the [Superfund] facility" (US Senate 1994).

The language of both House and Senate versions of the reauthorization of CERCLA would have required USEPA to 
involve the public to an unprecedented degree in superfund decision-making, from the very outset of a project. Clearly, an intent of these changes was to avert the political consequences of such unpopular superfund response decisions as USEPA's 1990 ROD, which called for the incineration of New Bedford Harbor's contaminated sediments. The future of this policy shift toward the greater involvement of local citizens in Superfund decision-making is now uncertain. 


\section{D. 4. The Greater New Bedford Community Work Group.}

Beginning in 1983, USEPA attempted to maintain a degree of public involvement in decisionmaking at the New Bedford Harbor superfund site by means of public informational meetings, pamphlets distributed in schools, and several public comment periods. In 1987, at the request of USEPA, the Mayor of New Bedford, John Bullard, appointed the Greater New Bedford Community Work Group (GNBCWG) to represent community interests to USEPA. The Work Group settled in at about ten active members representing a variety of community interests. (USEPA 1990).

In 1989, as USEPA's plan to dredge and incinerate the Acushnet's most contaminated sediments became public, the Agency awarded GNBCWG a $\$ 50,000$ TAG. The purpose of this grant was to allow the citizens' group "to conduct an independent analysis of EPA's site investigation findings and evalution of cleanup options" (USEPA 1992a). In 1990 the Group voted on USEPA's Hot Spot Proposed Plan as part of the public comment process, voting six to three in favor of the incineration-dependent preferred alternative (USEPA 1990c). In 1991 the original GNBCWG disbanded; it was reformed with new members in 1992, and disbanded again in 1993 (Duckworth 1993). With its 1990 vote, however, it had given USEPA the trappings of public approval for incineration of the New Bedford Harbor sediments. In reality, USEPA's incineration decision was extremely controversial. 


\section{D. 5. Conflict over remediation.}

while the "official" public group involved in the New Bedford Harbor Superfund Site, the GNBCWG, was ratifying USEPA's decision to incinerate the Hot Spot sediments, public opposition to the incineration was coalescing on a variety of levels. In the early 1990's, three citizens' groups formed to oppose USEPA's incineration plans: Hands Across the River (HATR); the Downwind Coalition (DC); and Concerned Parents of Fair Haven ( $\mathrm{CPFH}$ ). These groups organized demonstrations and lobbied municipal, state, and Tederal representatives to block USEPA's plan, enlisting the aid of national anti-incineration groups such as Greenpeace and the Citizens' Clearing House for Hazardous Waste (Starr, 1993) ${ }^{50}$. Inspired, perhaps, by the recently released United Church of Christ report (1987) showing a nationwide racial bias in the location of hazardous waste sites, the groups charged that USEPA's decision was colored by "environmental racism" toward the poor, largely ethnic community of the North End of New Bedford. Their claim was bolstered by the fact that a USEPA decision to incinerate PCBS at the Massachusetts Military Reservation had been recently defeated by public opposition in the nearby suburban community of Bourne, Massachusetts (Allen 1992b).

${ }^{50}$ The Citizen's Clearinghouse for Hazardous waste was established by the citizen-organizers of the Love Canal movement. 
Opposition to USEPA's incineration plans appears to have been broad-based and to have been shared by some members of New Bedford's City Council. In 1991, the City Council held a non-binding referendum to gauge public opinion of USEPA's plan, in which two-thirds of participants voted against incineration. However, the wording of the ballot did not explain that the incineration was just one component of a broad clean-up plan for the harbor, nor that the installation of the incinerator would be temporary; it is therefore impossible to determine to what extent citizens were rejecting USEPA's cleanup plans, specifically, versus the general idea of waste incineration in New Bedford (Allen 1992a; Sebastian 1993).

In spite of the apparent groundswell of public opposition to incineration, USEPA moved toward implementation of the project in accordance with the 1990 ROD. By mid-1993, well behind schedule, the Agency's contractor, Perland Environmental Technologies, began assembling the wastewater treatment component of the remediation system. On July 15, the New Bedford City Council unanimously passed an ordinance banning the transportation of "devices or mechanisms of any kind used in incineration or water treatment through the streets or airspace of the city without first obtaining a permit from the mayor and city council" (New Bedford City Council 1993). The action catapulted the issue into the front pages of the New Bedford Standard-Times and prompted USEPA to file suit 
for civil penalties $(\$ 25,000$ per day, the maximum provided for by CERCLA) and injunctive relief from the ordinance in Federal District Court, Boston. On September 29, 1993, Judge William G. Young enjoined New Bedford from enforcing its ordinance against USEPA, and enjoined the City from "obstructing, impeding or otherwise interfering with entry and access by the Environmental Protection Agency [and] the U.S. Army Corps of Engineers...to the Hot Spot Operable Unit of the New Bedford Harbor Superfund Site". The Agency agreed to dismiss its claim for civil penalties when New Bedford agreed to allow USEPA full access to the site (United States of America v. City of New Bedford, Massachusetts, 1993).

The Agency's legal success in enforcing its incineration decision seems to have been matched by political failure. Members of the City Council and of the activists' groups convinced State and Federal lawmakers to join them in opposing incineration. US Senators John Kerry and Edward Kennedy and US Congressman Barney Frank lobbied Carol Browner, the newly appointed Administrator of USEPA, to consider alternative technologies for the cleanup (Collins 1993; Shaw 1994). Frank also lobbied the white House, involving the General Accounting office as well as Leon Panetta, President Clinton's budget director (Glass and Corey 1993).

The way had been cleared, legally, for USEPA Region I to continue with its incineration plans. However, the 
regional office was strongly encouraged behind the scenes, by the Administrator as well as by Judge Young, to attempt to settle the dispute through mediation (Garmon 1994; Shaw 1994). The Agency enlisted the help of the Massachusetts Office of Dispute Resolution, which had recently mediated negotiations at New Bedford's other Superfund site, the Sullivan's Ledge landfill (Massachusetts Office of Dispute Resolution 1993).

The Office of Dispute Resolution (ODR) was established in 1990 by the State General Assembly "to assist agencies and officers of the executive, legislative, and judicial branches of the commonwealth, as well as any city or town to improve the resolution of disputes that arise within their respective jurisdictions" (M.G.L. 1993, Ch. 7, Sec. 51). The office set about assembling a group of stakeholders and professionals which would become known as the New Bedford Harbor Superfund Site Committee. Committee members were selected using a consensual, inclusive approach, in an attempt to represent as many stakeholders as possible.

The three ad-hoc citizens' groups are each represented: Hands Across the River; Concerned Parents of Fairhaven; and the Downwind Coalition. Legal, technical, and managerial representatives of USEPA sit across the table from the citizen representatives, as do representatives of the National Oceanic and Atmospheric Administration (NOAA) and the Massachusetts Department of Environmental Protection (DEP), the Federal and state natural resource trustees for 
the site, respectively. Elected officials and municipal representatives include three New Bedford City Councillors; State Senator Mark Montigny and State Representative William Straus; and representatives of Fair Haven, Acushnet, and the New Bedford Mayor's office. Meetings are public, but participation is generally limited to committee members. The discussions are chaired by Michael Keating, a Providence lawyer and expert on alternative dispute resolution who was selected by the participants to serve as an impartial facilitator. Keating is assisted by one of ODR's staffmembers (Wells 1994).

Roughly 20 people take part in each meeting; generally, the same individuals attend each meeting, so a rapport has developed. The discussions began with an expression of interests by each participant. Since then, the group has been reviewing alternatives to incineration for the remediation of the Hot spot sediments, in hopes of developing a consensus regarding treatment of the contaminated sediments of the upper Acushnet River. The progress of the discussions led Frank Ciavattieri, head of USEPA Region I Waste Management Division, to announce on 12 July 1994 that Region I had cancelled its contract with Perland Environmental Technologies to incinerate the Hot Spot sediments (Ciavettieri 1994). 


\section{The Problem}

II. A. Difficulty of siting noxious facilities.

Much recent research has suggested that locational

disputes over hazardous facilities result, in part, from differences in risk perception between the "risk professionals" who make siting decisions, and the public who must live in the shadow of such facilities (e.g., Cvetkovich and Earle, 1992; Slovic, 1987). Uncertainty is inherent to the science of risk assessment (Patton, 1993). To complicate matters in New Bedford's case, there is no "zerorisk" option; the choice lies between the risks presumably inherent in the existing contamination in the waterway, versus a set of equally uncertain potential risks resulting from various cleanup options, such as incineration.

Alternative Dispute Resolution (ADR) is an umbrella term which encompasses a variety of structured discussion techniques which have been used increasingly in recent years to attempt to resolve environmental disputes in a consensual, non-litigious manner (Fischer, 1993; Mosher, 1983). In the New Bedford case, ADR has taken the form of "facilitated discussions," coordinated by the Massachusetts Office of Dispute Resolution (ODR).

If, as the literature suggests, differences in risk perception between professionals and the public are a source of environmental disputes, then one definition of effectiveness in resolving such disputes would be the 
reduction of such differences. The problem which this study examined, therefore, was whether $\mathrm{ADR}$ had, in this instance, reduced differences in risk perception between "risk managers"--environmental professionals--and "stakeholders"-residents of the towns adjoining the Acushnet River.

In order to measure perceptions of a variety of risk and trust issues related to the contamination of the Acushnet River, as well as USEPA's efforts to remediate this contamination, the study employed a descriptive survey. The data so gathered were compared among professionals and nonprofessionals, involved and uninvolved in ODR's facilitated discussions, in order to discover whether the perceptions of the two camps within the discussions were closer than those ithout. Such a relationship would demonstrate the effectiveness of ODR's facilitated discussions. In addition, the survey examined public knowledge about the New Bedford Harbor Superfund Site in order to shed light on the nature of the conflict, and to identify areas in which the dissemination of information to the public regarding the site might have been improved. 


\section{B. Review of related literature.}

II. B. 1. Risk perception, assessment, and uncertainty.

Human activities give rise to a broad and diverse range of technological hazards: from minor releases of pollutants to catastrophic nuclear and chemical plant accidents; from automobile accidents to the collapse of dams (Cutter 1993). "Risk" refers to the danger arising from hazards, incorporating the concept of probability (Lewis 1990). Or, as Mary Douglas (1990) has written, "[r]isk is unequivocally used to mean danger from future damage." Given adequate data, well-defined technological risks of relatively high probability, such as death by automobile accident, are easily quantified (though not necessarily without controversy). Low-probability risks, or those which slightly elevate existing background risks, such as those attending the contamination of New Bedford Harbor or incineration of its sediments, are, conversely, extremely difficult to estimate, even if well-defined (Lewis 1990; Slovic 1987).

Quantitative risk assessment is fundamental to governmental environmental decisionmaking (Patton 1993; Russell and Gruber, 1987). In the case of carcinogenic and toxic chemicals, risk assessment uses extrapolations from animal data to attempt to estimate the average probability that a particular consequence will result from a given level of exposure to a particular substance. Probabilities so 
obtained are used by USEPA as the foundation for risk management, the process by which the Agency decides whether and how a risk should be regulated or mitigated (Patton 1993). While risk assessors work to err on the side of conservatism, the methodology of risk assessment necessarily employs a good deal of inference, extrapolation, and assumption, so that quantitative risk assessment is inherently uncertain (Patton 1993; Sheuplein 1993; Russell and Gruber 1987). According to Freudenburg and Pastor (1992), "[q] uantitative estimates of overall risk are likely to involve the tyranny of illusory precision." Moreover, recent behavioral research has shown that expert risk assessments are built largely upon subjective judgements (Gardner and Gould, 1989). If one accepts these points of view, then, the truly objective risk quantification becomes an impossibility.

To the extent that federal decisionmaking sees risk as something which can be accurately quantified, it takes a technical, or objectivist, view of risk. In contrast to this model is one proposed by researchers in the behavioral sciences, which might be referred to as the constructionist, or subjective, view. According to this view, risks and hazards are broad social phenomena, functions of collective actions and judgements with respect to the physical world. Within this paradigm, perception becomes more important than efforts at quantification (Cutter, 1993; Cvetkovich and Earle, 1992), while "risk" refers not just to chance of 
death or loss of "statistical lives," but incorporates an array of undesirable effects (Gardner and Gould, 1989).

The study of risk perception originally concerned itself with natural hazards, but has since evolved to deal largely with technical ones. The work may be divided into two broad categories: that which utilizes a primarily psychological approach, and that which is essentially spatial. The former is characterized by emphasis on cognitive aspects of risk perception (often utilizing controlled experiments) while the latter is more functionally oriented, generally site-specific, and often concerned with the relationship between behavior and political or physical action (Cutter 1993).

Starr (1969) was among the first to attempt to quantify public perception of technological risks, employing a lrevealed preference" methodology to draw conclusions about ie risks and benefits of technologies based upon historical data (Slovic 1987). This approach was superceded by what Lovic refers to as the "psychometric paradigm:" the use of "expressed preferences" or survey methodology to show that different groups perceive given risks in quantifiably different ways, and that, conversely, different risks can be distinguished by quantifiable characteristics using factor analysis (Slovic 1987).

In the groundbreaking Risk and Culture (1982), however, Douglas and Wildavsky offer a far more subjective view of risks and risk perception. Drawing on anthropology as well 
as political theory, these authors argue that risks are "cultural constructs." That is, while risks are often real (though frequently hidden), their perception and selection are functions of particular cultural biases.

By 1990, Wildavsky and Dake could describe three major theories of risk perception prevalent in the social sciences. "Knowledge theory" posits the idea that people perceive risks because they actually know things to be dangerous. "Personality theory," conversely, proposes that risk perception is a function of one's personality, while "economic theory" sees a personal cost-benefit calculus driving risk perception. These researchers conclude that personality variables tend to be the best predictor of attitudes toward environmental risks. Similarly, Samdahl and Robertson (1989) examined the existing body of work as well as their own questionnaire, concluding that while socioeconomic variables are generally poor predictors of environmental concern, political ideology corresponded strongly with pro-environmental values.

Other researchers have examined the psychological context of complex environmental decisionmaking, including that concerned with technological risk. A number of researchers have shown that, faced with a great deal of complicated information, individuals--experts included-employ "cognitive oversimplification" or heuristic methods to arrive at a decision (Miller 1985, Varis 1989). Miller (1985) shows that such simplification inevitably results in 
decisionmaking bias, distinguishing between "cognitive bias"--that which results from the simple inability to incorporate all relevant factors into a decision--and "motivational bias"--that which is driven by ulterior motives.

In contrast to these psychological approaches to the study of risk perception, geographers have taken a more functional or contextually-oriented approach, examining the factors influencing individual or group response to actual situations (Cutter, 1993). Furuseth (1990), for example, has explored spatial aspects of citizen response to the siting of a sanitary landfill in North Carolina, one of a number of investigations into the dimensions of the NIMBY (Not In My Backyard) phenomenom. This study found that, while a spatial dimension to citizens' objections to the siting did exist, it was by no means the only important predictor of response. Hatfield (1989) compared groups involved in the siting of a hazardous waste incinerator in Southern California, using factor analysis to examine how attitudes toward specific siting variables differed among groups. Interestingly, he found survey respondents who attended public meetings on the issue to be significantly more risk-averse than respondents contacted by mail.

Several researchers have used survey-based risk perception studies to attempt to weigh perceived costs and benefits of technologies. Cutter (1984) used a series of questionnaires to examine public assessment of risks and 
benefits of the Three Mile Island nuclear plant, while Gardner and Gould (1989) compared residents of Arizona and connecticut with respect to perceived risks, benefits, and acceptability of several technologies.

II. B. 2. The nature of locational disputes: Differences in perception; NIMBY and LULU.

Much recent work has shown that differences in risk perception between professionals and laypeople are a primary source of conflicts over environmental technology (e.g. Fort et al. 1993; Cvetkovich and Earle 1992; Gardner and Gould 1989; Slovic 1987; Miller 1984). Miller (1984) has shown that this disparity results, in part, from inherent biases held by experts and laypeople, including biases resulting from media coverage and attitudes of distrust toward certain categories of individuals, such as representatives of government. Moreover, the two groups may define "risk" in this context in entirely different ways (Slovic, 1987). Professional environmental managers tend to define risk in terms of probability of death or injury while laypeople employ a broader calculus, taking into account more qualitative factors. These include the existence of disagreement among experts; the degree of equity with which risks are borne (Gardner and Gould 1989); effects upon property values (Cvetkovich and Earle 1992); and the degree of public control over the selection of risks (Fiorino 1989). 
Two acronyms have come to describe local public resistance to the siting of technological facilities: ${ }^{1}$ NIMBY (Not In MY Back Yard) and LULU (Locally Unwanted Land Use). The two terms regard the same phenomenom from slightly different perspectives. Those who use NIMBY "tend to see only the location, not the technology, as problematic," while users of the term LULU implicitly acknowledge that certain types of facilities are likely to meet with public opposition regardless of their proposed location (Freudenburg and Pastor 1992). Hazardous waste treatment facilities are among the least wanted (Popper 1981). Popper has argued that LULUs are an unavoidable fact of land-use planning, but that a variety of tactics exist to increase community acceptance, such as on-site mitigation and goodfaith public involvement. Numerous studies have explored the idea of monetary compensation to communities in return for siting a LULU (e.g. Portney 1985; Fort et al. 1993). Other investigations have shown that. social distrust--lack of public confidence in government and/or industry--is often an important part of the conflict surrounding these LULUs (e.g. Cvetkovich and Earle 1992; Kasperson et al. 1992; reudenburg and Pastor 1992). Freudenburg and Pastor argue that, to move toward the minimization of LULU controversies, research is needed which crosses the boundary between professionals and the public. They call for "more research

${ }^{1}$ As well as other types of controversial facilities, such as prisons, homeless shelters, and sex-related businesses. 
which is genuinely comparative -- treating as problematic not just the views of the general public, but of both the public and the technical community (1992).

\section{B. 3. Public participation in environmental decisionmaking .}

A subtext of much recent risk perception literature-particularly that written from the social science perspective--is the desirability of increasing local public involvement in environmental decisionmaking. Goals of increased participation include enhancing the acceptability of LULUs as well as the furthering of democratic ideals (Kasperson et al. 1992; Fiorino 1989; Kasperson 1986;

Portney 1985). Arnstein (1969) pointed out that there is a hierarchy of citizen involvement in government decisionmaking, ranging from the nominal ("tokenism") to the actual ("citizen power"). An objective of some risk perception studies has been to forge, a theoretical link between perception and participation, i.e., to explain citizen action (Cutter 1993).

\section{B. 4. Alternative dispute resolution.}

Clearly, a priori public involvement is more efficient than a protracted environmental dispute (which is not to suggest that either is inevitable, nor that the two are mutually exclusive). Once a dispute does occur, it may be resolved either by legal proceedings or by alternative 
dispute resolution (ADR). Cormick (1980) has argued that $A D R$ requires and promotes the more developed model of citizen participation, that which empowers the public. While a number of authors have advocated the use of ADR for the resolution of environmental disputes (e.g. Fischer 1993; Mosher 1983), there have been relatively few attempts to critically assess the effectiveness of ADR (Nakamura et al. 1991; Wells 1994). Nakamura et al. examined a failed effort at ADR concerning a superfund Site in upstate New York, concluding that $A D R$ must be properly managed in order to carry a high probability of success.

\section{B. 5. Justice, equity, and public involvement under Superfund.}

A recent, yet growing, body of literature is concerned with "environmental equity:" the social justice aspect of environmental decisionmaking. A landmark study on this topic was that commissioned by the United Church of Christ (1987), which examined the relationship between ethnic and racial variables and the locations of hazardous waste sites and commercial hazardous waste treatment facilities nationwide. Controlling for socioeconomic variables, the study found high correlations between race and ethnicity and proximity to hazardous waste sites. Research by Hird (1993) agreed that superfund sites are more likely to occur in communities with more non-white residents, but found a positive correlation between wealthier communities and the 
frequency of hazardous waste sites. Hird's research found great variability in the cost-effectiveness of superfund, concluding that costs per statistical life saved ranged from $\$ 340,000$ to $\$ 77$ billion. The limit of cost-effectiveness for environmental clean-ups is generally considered to be $\$ 10$ million per statistical life saved (Hird, 1993). 


\section{C. Significance of the study.}

The outcome of this research has significance for the pending reauthorization of Superfund's enabling legislation, the Comprehensive Environmental Response, Compensation, and Liability Act of 1980 (CERCLA) as amended by the superfund Amendments and Reauthorization Act of 1986 (SARA).2 Arguably, CERCLA's weak requirements for public involvement in superfund decisionmaking are partly to blame for the magnitude of the current dispute. In an attempt to reconcile the opposing sides, the facilitated discussions chaired by the Massachusetts Office of Dispute Resolution (ODR) have involved the public to a much greater degree than required by CERCLA. If the discussions have indeed accomplished their purpose, a strong case could be made for expanding CERCLA's public involvement requirements when the law is reauthorized. Moreover, the revision might be worded so as to encourage the type of consensual process typified by ODR's facilitated discussions, rather than litigation, to resolve the public/governmental conflicts which inevitably arise under superfund. A relevant question for CERCLA, therefore, is: have ODR's facilitated discussions been working? That is, have they caused the hazard perceptions of citizens and managers, regarding the New Bedford Harbor Superfund site and its remediation, to converge?

${ }^{2} 42$ U.S.C. Section 9601 et seq. 


\section{The method.}

III. A. Hypotheses.

\section{A. 1. General Hypothesis.}

In general, the research hypothesized that a particular facilitated discussion had enhanced the potential for the resolution of a local/Federal conflict regarding a coastal Superfund Site. Specifically, it was hypothesized that participation in ODR's facilitated discussions had reduced the differences in risk perception between the disputants in the case of the New Bedford Harbor Superfund Site. These disputants were characterized as follows:

1. Those who opposed incineration: local citizens and their representatives--the three ad hoc environmental groups as well as local politicians.

2. Those who favored incineration: Federal and state coastal resource managers--specifically, representatives of USEPA and DEP.

\section{A. 2. study groups.}

In order to test the general hypothesis at a discrete point in time, the two disputant groups were subdivided so that differences in risk perception between citizens and managers within ODR's discussions might be compared with differences in risk perception between citizens and managers uninvolved in the discussions. In other words, the following four sub-groups of stakeholders were regarded for analysis: 
Group 1: Citizens' representatives who participated in the facilitated discussions chaired by ODR.

Group 2: Citizens of the Greater New Bedford Metropolitan Area who had not participated in these facilitated discussions, represented by a random sample.

Group 3: Coastal resource managers included in the facilitated discussions chaired by ODR.

Group 4: Coastal resource managers who were uninvolved in these facilitated discussions, represented by a nonrandom sample.

III. A. 3. Assumptions.

In order to establish the context of the hypothesis,

the research employed the following assumptions:

Assumption 1: It is assumed that the current perceptions of Group 2, regarding hazards associated with the New Bedford Harbor Superfund Site and its remediation, are statistically similar to the perceptions of Group 1 at the point at which these citizen representatives became involved in ODR's facilitated discussions.

Assumption 2: It is assumed that the current perceptions of Group 4, regarding hazards associated with the New Bedford Harbor Superfund Site and its remediation, are statistically similar to the perceptions of Group 3 at the point at which these coastal resource managers became involved in ODR's facilitated discussions.

III. A. 4. Major Hypothesis.

It was hypothesized that the involvement of individuals

in the series of facilitated discussions chaired by ODR reduced the differences in hazards perception between the two opposing sides in the dispute over the remediation of the the New Bedford Harbor Superfund Site. 
III. A. 5. Hypothetical model.

The study's major hypothesis may be represented graphically by positioning the perceptions of the four study groups along a continuum, as follows.

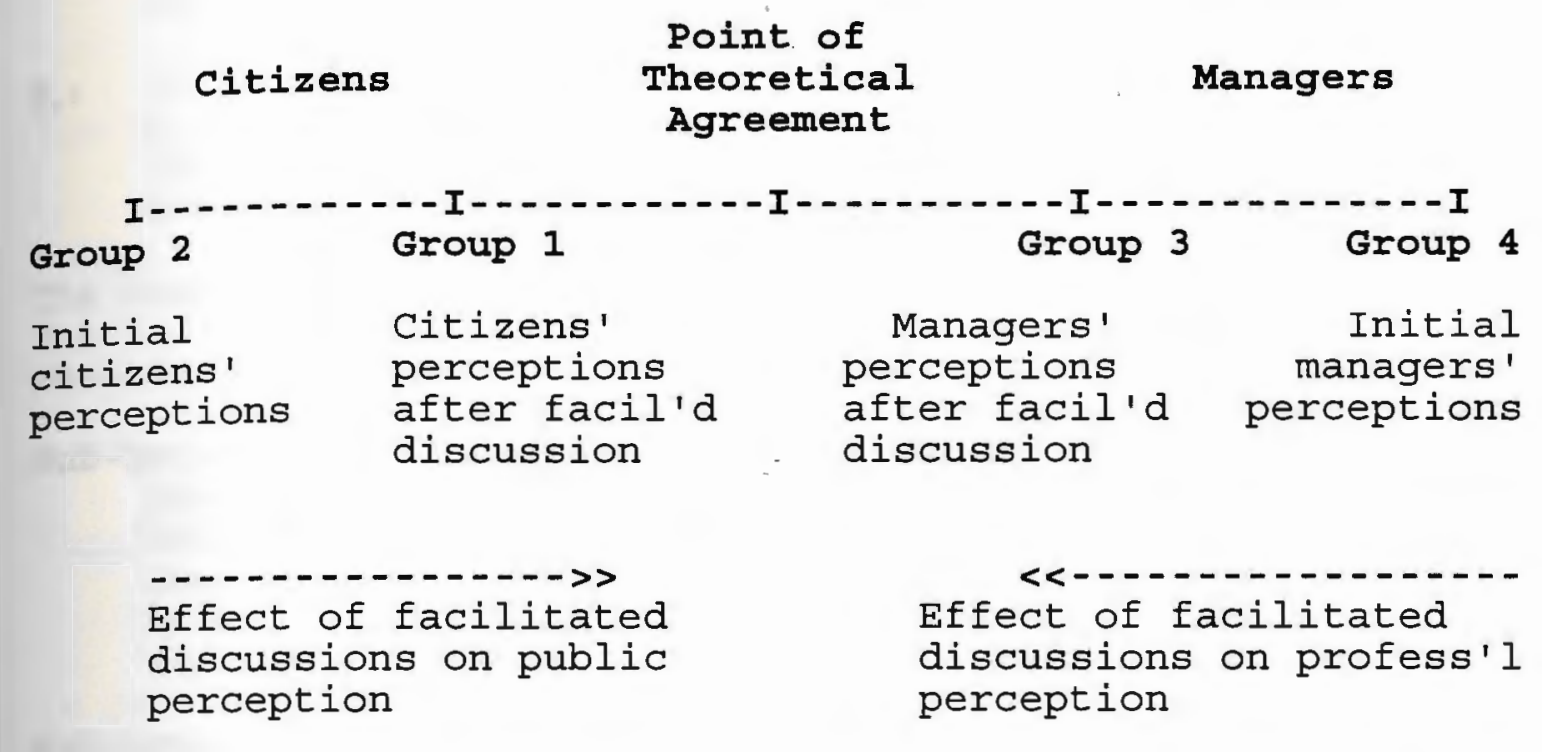

This model incorporates, implicitly, two hypothetical ideas:

1) The difference in perception between Groups 1 and 3 is smaller than the difference in direction between Groups 2 and 4.

2) The two public groups (Groups 1 and 2) lie at one end of the continuim, while the professional groups ( 3 and 4) lie at the other.

In other words, while the facilitated discussion has brought the two sides closer together, it has not changed the direction of individuals' perceptions to any significant degree. That is, few if any individuals have switched sides in the debate as a result of participation in the facilitated discussions. 
III. A. 6. Research hypotheses.

The two-tailed null and research hypotheses may be

expressed as follows:

$\mathbf{H}_{0}$ : It is hypothesized that there are no statistically significant differences in the measured perceptions of the four groups, regarding the hazards associated with the New Bedford Harbor Superfund Site.

$\mathbf{H}_{\mathbf{T}}$ It is hypothesized that there are statistically significant differences in the measured perceptions of the four groups, regarding the hazards associated with the New Bedford Harbor Superfund Site.

The research hypothesis is in turn subdivided into three one-tailed sub-hypotheses, as follows:

Sub-hypothesis 1: It is hypothesized that the difference in perception between Group 1 and Group 3, regarding the hazards associated with the New Bedford Harbor Superfund Site and its remediation, is, to a statistically significant degree, less than the difference in perceptions between Group 2 and Group 4.

Sub-hypothesis 2: It is hypothesized that the difference in perception between Group 1 and Group 2, regarding the hazards associated with the New Bedford Harbor Superfund site and its remediation, is, to a statistically significant degree, less than the difference in perceptions between Group 1 and Group 4 .

Sub-hypothesis 3: It is hypothesized that the difference in perception between Group 3 and Group 4, regarding the hazards associated with the New Bedford Harbor Superfund Site and its remediation, is, to a statistically significant degree, less than the differences in perception between Group 3 and Group 2 .

The three sub-hypotheses may be graphically represented in relation to the main hypothesis as follows: 
Group $2 \quad$ Group $1 \quad$ Group $3 \quad$ Group 4

Sub-hypothesis 1: $(|G 1-G 3|)<(|G 2-G 4|)$

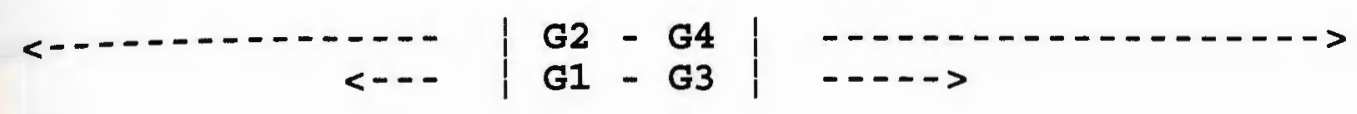

Sub-hypothesis 2: $(|G 1-G 2|)<(|G 1-G 4|)$

$<-|G 1-G 2|-><-----\mid$ | G1 - G4 |

Sub-hypothesis 3: $(|G 3-G 4|)<(\mid G 3-G 2)$

| G3 - G4 | -

Where $\mid$ G1 - G2 $\mid=$ the difference in perception

between Group 1 and Group 2, etc.

In practice, statistical testing of survey results needed to be undertaken only where the general order of the expected relationship was initially apparent, based on margin totals of the results. In other words, a simple examination of the margin totals (mean by group for Likert-scale questions; percent frequency by group for frequency-based questions) showed whether the position of each group along the perceptual continuum was the same as that of the hypothetical model, for a given survey question. Where the expected relationship was not so apparent, $\mathbf{H}_{\mathbf{r}}$ could be rejected without statistical testing. Where the general order of the hypothetical model was apparent, statistical testing for differences among groups was undertaken, in 
order to determine whether the differences among groups were statistically significant.

Statistical results which supported the existence of the hypothesized model would suggest that the process of dispute resoloution had, in this particular case, moved opposing sides toward compromise. If, however, statistical testing resulted in the acceptance of the null hypothesis, concerns would be raised regarding the possible failure of the process of dispute resolution. Faced with such an outcome, the study would be forced to ask, what do the survey data tell us about the nature of the dispute and its reconciliation, in the context of public perception of the New Bedford Harbor Superfund Site? 


\section{B. Study area and sample population.}

The delineation of a study area for a project such as this was necessarily somewhat arbitrary, since decisionmaking affecting the New Bedford Superfund site occurs as far away as Boston and Washington and as near as the nearest resident--a mere stone's throw from the Hot Spot.

In the case of Groups 1 and 3--participants in ODR's facilitated discussions--there was no choice in the matter if the sample were to be comprehensive. In fact, most of the citizen representatives (Group 1) reside in the same three-town area as the public random sample (Group 2); geveral live in the surrounding towns: Dartmouth, Mattapoisett, or Marion, Massachusetts. Most of the professional participants (Group 3) work in Boston.

In the case of Group 4--professionals uninvolved in ODR's discussions--the study attempted to define the sample which was a) most nearly comparable to Group 3 , and b) most likely to be generally familiar with the New Bedford Harbor site: marine resource professionals working in the Southeastern Massachusetts region.

Group 2--the public random sample--was by far the largest of the four study groups. The three Massachusetts towns of New Bedford, Fair Haven, and Acushnet were chosen as the study area for this group because they adjoin the Acushnet River; thus all are directly affected by the contamination of the river and by the superfund cleanup. 
Moreover, they were the three towns best represented on the facilitated discussions, and the only towns formally represented thereon. The choice of this area allowed Group 2 to be as nearly comparable, geographically, to Group 1 as possible. Sample size for Group 2 was determined on a strictly pragmatic basis--it was as large as was feasible with the resources available at the time. 


\section{C. Survey design.}

Two forty-question survey instruments were used in the study: one for the two public groups (Groups 1 and 2 ) and one for the two professional groups ( 3 and 4 ). The two Mersions had different sets of introductory questions but shared thirty-three "core questions." Cover letters differed slightly among the groups. Appendix B includes complete survey texts: introductory questions, core questions, and sample cover letters.

The most important step in designing the survey instrument was to determine the defining issues in the dispute between citizens and managers regarding the New Bedford Harbor Superfund site. The primary source for this investigation was a videotape of the second of ODR's facilitated discussions, held on January 5, 1994, at the Greater New Bedford Vocational High School. At this meeting, each participant was asked by the facilitator to put forth their interests regarding the superfund site. They were asked not to make position statements, but rather to state concerns with the course of the remediation process (City of New Bedford 1994).

The discussion participants cited a fairly broad range of concerns. At this time the most intense point of disagreement concerned the health risks associated with incineration of the Hot spot sediments. Other areas of dispute included severity of ambient site risks; importance of expediting the clean-up; the validity of USEPA's past 
public participation efforts; and the existence of bias in government decisionmaking. Summarized and organized, the discussion yielded fourteen major points of disagreement, which could be grouped under seven general headings. The results of this procedure are detailed in Appendix A.

once identified, these issues became the basis for the study's questionnaire. The thirty-three "core questions" were designed to measure four broad categories of perception relevant to the New Bedford Harbor Superfund Site: perceived risk of the existing contamination; perceived risk of USEPA's remediation plans; trust in the Government's ability to deal with the site; and the effectiveness of Government's communication about the site. As mentioned, the core questions were included the surveys administered to all four groups. Questions utilized Likert scales, rank-order questions, and forced-choice formats.

In addition, two sets of seven introductory questions were created: one for the public survey administered to Groups 1 and 2; the other for the professional survey given to Groups 3 and 4. Introductory questions in the public survey sought to discern basic demographic variables, degree and sources of knowledge about the site, and personal attitudes toward risk. Those in the professional version were intended to determine the managers' role in site management and general attitudes toward citizen involvement, as well as, again, personal attitudes toward risk. 
A prototype of the public survey was pre-tested in New Bedford and Fairhaven on June 28 and 29, 1994. I knocked on the doors of six houses, chosen arbitrarily, introduced myself, and asked the residents to complete the survey. In half the cases I was able to sit and talk with the respondent while he or she filled out the survey; in all cases, I discussed it with them afterward.

It was immediately apparent that there was a great deal of interest in the New Bedford Harbor Superfund Site among local people; it seemed, therefore, that residents did not regard the ten-page survey to be as onerous as they otherwise might have. Generally, the pretest respondents seemed to find that the survey required some thought, but was not difficult, although they found some questions to be in need of clarification. These were revised in the subsequent, and final, version.

An interesting, but unexpected, influence upon survey results came to light during these pretest discussions. During the spring and summer of 1994, the New England Fisheries Management Council and the National Marine Fisheries Service were implementing Amendment 5 of the Northeast Multispecies Management Plan--the "Groundfish Plan"--as well as Amendment 4, the "Scallop Plan." The provisions of these plans amounted to the most severe regulation ever placed upon New England fisheries, including strict limits on catch quantities and vessel-days-at-sea, as well as stringent gear regulation. Many New England 
fishermen were outraged. New Bedford fishermen brought their boats to Boston to protest the plans in February and March of 1994; many expressed a belief that the Government was trying to put them out of business (Pollack 1994a and 1994b) .

During the pretest, respondents with personal ties to the commercial fishing industry expressed great antipathy toward the Federal Government, which they perceived as foisting draconian regulations upon them. This sentiment clearly influenced attitudes toward Government decisionmaking regarding the New Bedford Harbor Superfund site. As a result of this discovery, the revised version of the survey included a question to establish how closely a respondent was connected with the scallop and groundfish industries, if at all.

The public version of the survey was translated into Portuguese and Spanish by native speakers. By preparing surveys in these languages, in addition to English, the study ensured that the survey instrument would be intelligible to at least $93.3 \%$ of residents over five years of age within the study area (US Department of Commerce, 1992b). During distribution of the surveys, those Spanish speakers encountered turned out to be equally comfortable with English or Portuguese; therefore, no Spanish surveys were administered. 


\section{D. Survey administration.}

\section{D. 1. Discussion participants: Groups 1 and 3 .}

Groups 1 and 3--citizens and professionals involved in ODR's facilitated discussions--were queried comprehensively. The Office of Dispute Resolution provided a list of forum participants and affiliations; based on group affiliations, participants were divided into citizen representatives versus professionals for study purposes. Facilitators were excluded from the study group, while elected officials were placed in Group 1 .

The discussion facilitators introduced me at one of the last of the forum's regular meetings, in July, 1994. I contacted each of the discussion participants soon thereafter, briefly describing the nature of the study, and asking them to complete a survey, with an assurance of confidentiality. I emphasized that I was looking for individual perceptions rather than official position statements. In all cases, the forum participants agreed to at least look at the survey, although some of the professionals expressed a concern that their responses would be kept truly confidential (one went so far as to say "I could lose my job over this"), while others communicated an initial unwillingness to separate their own ideas from that of their employer. Subjects were then mailed surveys (public or professional, as appropriate) along with a 
personalized cover letter and return envelope. Survey response rates for Groups 1 and 3 were as follows:

Table 3.1: Survey distribution and response: forum participants, Groups 1 and 3 .

\begin{tabular}{|c|c|c|l|l||}
\hline Group & $\begin{array}{l}\text { Number of } \\
\text { individuals }\end{array}$ & $\begin{array}{l}\text { Number who } \\
\text { agreed to } \\
\text { be surveyed }\end{array}$ & $\begin{array}{l}\text { Number of } \\
\text { surveys } \\
\text { returned }\end{array}$ & $\begin{array}{l}\text { Response } \\
\text { rate }\end{array}$ \\
\hline Group 1 & 13 & 12 & 8 & $66.7 \%$ \\
\hline Group 3 & 11 & 11 & 9 & $81.8 \%$ \\
\hline
\end{tabular}

The list of participants in the facilitated discussions when the surveys were administrated may be found in Appendix C.

III. D. 2. Professional non-participants: Group 4. The study's Group 4 (marine resource managers uninvolved in ODR's facilitated discussions) was chosen in a non-random, non-comprehensive manner. Admittedly, this is a weak selection method in terms of validity; however, it was the only practical way to assemble an adequate number of individuals with the required characteristics. Subjects for this segment of the study were chosen from my own acquaintances in the field of environmental management and these professionals' referrals. Criteria for selection were as follows:

1. That the individual was involved in any aspect of environmental or coastal management on a professional level.

2. That $s /$ he was working in Massachusetts, and professed at least a general knowledge of the New Bedford Harbor Superfund Site.

3. That $s$ he had at no time been an active participant in ODR's facilitated discussions. 
In order to ensure that Group 4 was approximately the same size as Groups 1 and 3, nine individuals were contacted. Methodology from this point was essentially the same as for Groups 1 and 3: after outlining the purpose of the study, I asked whether they would be willing to participate. In most cases, they initially agreed. A copy of the professional version of the survey was then mailed to each, along with a personalized cover letter and return envelope. After reading the survey, one member of Group 4 declined to participate: an employee of NOAA, who simply said that he did not feel that his completion of the survey would be "appropriate." Distribution and returns were as follows:

Table 3.2: Survey distribution and response: professionals uninvolved in forum, Group 4.

\begin{tabular}{|c|c|c|c|c||}
\hline Group & $\#$ queried & $\begin{array}{c}\# \text { agreed/ } \\
\text { distributed }\end{array}$ & $\#$ returned & $\begin{array}{c}\text { Response } \\
\text { rate }\end{array}$ \\
\hline 4 & 9 & 8 & 7 & $87.5 \%$ \\
\hline
\end{tabular}

III. D. 3. Public random sample: Group 2 .

In order to query the non-aligned New Bedford area public (Group 2), the public version of the survey was administered to a stratified random sample of residents of New Bedford, Fair Haven, and Acushnet from $6-27 \mathrm{July}$, 1994. Using the approach described by West (1993), ten random traverses were laid across a map of the study area (Champion Map Corporation, 1990). City blocks were selected at random intervals along these lines; rural areas were 
excluded. The distribution and return of surveys to, and from, Group 2 is fully described by Table 3.3.

Table 3.3: Distribution and return of surveys by town: Group

2.

\begin{tabular}{|l|l|l|l|l|l|l|l|l||}
\hline TOwn & Pop. & $\begin{array}{l}\% \\
\text { tot. } \\
\text { pop. }\end{array}$ & $\begin{array}{l}\text { \# of } \\
\text { blcks } \\
\text { sam'd }\end{array}$ & $\begin{array}{l}\text { \# of } \\
\text { surv } \\
\text { /blk }\end{array}$ & $\begin{array}{l}\text { tot. } \\
\text { dist } \\
\text { dist }\end{array}$ & $\begin{array}{l}\text { \% } \\
\text { tot. } \\
\text { dist }\end{array}$ & $\begin{array}{l}\text { \# } \\
\text { ret 'd }\end{array}$ & $\begin{array}{l}\% \\
\text { tot . } \\
\text { ret d }\end{array}$ \\
\hline N.B. & $\begin{array}{l}99, \\
922\end{array}$ & 79.5 & 19 & 7 & 133 & 78.6 & 84 & $63.2 \%$ \\
\hline Acsh & 9554 & 7.6 & 2 & 7 & 14 & 8.3 & 7 & $50 \%$ \\
\hline F.H. & $\begin{array}{l}16, \\
132\end{array}$ & 12.8 & 11 & 2 & 22 & 13.0 & 19 & $86.4 \%$ \\
\hline TOT. & $\begin{array}{l}125, \\
608\end{array}$ & 99.9 & 33 & & 169 & 99.9 & 110 & $65.1 \%$ \\
\hline
\end{tabular}

I administered the Group 2 surveys personally, going door to door, weekdays during evening hours; my method was adapted from that used by Fenton and Syme (1989) for a study of Australians' perceptions of the coastal zone. Beginning at the northeast corner of each selected block, I moved clockwise about the interior of the block, knocking on each door. If the necessary number of surveys could not be distributed within the interior of the block, I then moved about the exterior; if the quota still had not been reached, I moved one block northward to repeat the process. Where the selected block was non-residential, I moved one block to the North, as many times as necessary to obtain a primarily residential block. In cases of mixed-use blocks, commercial establishments were omitted from the survey. Multi-story, multi-family dwellings--the tenements which comprise most of the housing within the study area--were approached at street 
level only, for practical reasons, although upper-story residents were often present in the ground-floor apartments, in which case they were asked to participate.

once someone answered a door, I introduced myself and asked whether an adult resident of that home was willing to complete a survey regarding "the contamination problem in the Acushnet River." In nearly all instances, residents were at least aware that such a condition existed. Of 211 residents with whom I spoke, 169 (80\%) agreed to complete the ten-page survey, confirming my initial impression of great local interest in this issue. If a resident wanted to discuss the Superfund Site with me, I would ask them to first complete the survey. Only one survey per household was distributed; residents were asked to be sure that only adults completed the survey. The survey, along with a selfaddressed stamped envelope, was left with residents who agreed to participate. As shown in Table 3.3, the overall response rate was approximately $65 \%$

If the resident expressed an unwillingness to participate, I would gently try to persuade them; if they were at all adamant, I did not persist. In perhaps half of the cases where a resident initially refused participation, I was able to convince them to complete a survey. Unfortunately, in a few cases where passions ran highest, I was unable to elicit cooperation. One elderly gentleman said: "I was a foreman at Cornell, and I know too much about what went on there to answer your survey!" Another said, "I 
worked at Aerovox for thirty-five years; they took bloodtests for that health study and found nothing wrong with me. I've done my part." Try though I might, I could convince neither to participate; this was a loss to the study, since the capacitor manufacturers for whom both men worked are considered to be the among the principal sources of the PCB contamination of New Bedford Harbor. 


\section{Analysis}

IV. A. Description of sample by group.

As explained in Chapter III, the study's survey was

distributed to four groups:

Group 1: Citizens' representatives who had participated in the facilitated discussions chaired by the Massachusetts Office of Dispute Resolution (ODR). Citizen-participants were queried comprehensively.

Group 2: Citizens of the Greater New Bedford Metropolitan Area who had not participated in these facilitated discussions, selected by means of a stratified random sample of New Bedford, Fair Haven and Acushnet residents.

Group 3: Coastal resource managers who had been involved in the facilitated discussions. Manager-participants were, like Group 1, queried comprehensively.

Group 4: Coastal resource managers who had not been involved in these facilitated discussions, represented by a non-random sample.

Distribution and return of surveys by group are summarized in Table 4.1 .

Table 4.1: Distribution and return of surveys by group.

\begin{tabular}{||c|c|c|c||}
\hline & Tot. \# Dist'd. & Response Rate & N for analysis \\
\hline Group 1 & 12 & $66.7 \%$ & 8 \\
\hline Group 2 & 169 & $65.1 \%$ & 110 \\
\hline Group 3 & 11 & $81.8 \%$ & 9 \\
\hline Group 4 & 8 & $87.5 \%$ & 7 \\
\hline TOTAL & 200 & $67.0 \%$ & 134 \\
\hline
\end{tabular}

Responses to the initial, descriptive section of the survey Questions 1-7, which differed for citizens and 
professionals), may be used to infer some general haracteristics of each study group:

Group 1: All respondents in Group 1 were long-term residents of the New Bedford area (minimum area residency 24 years). Of the $75 \%$ of this group who chose to describe their employment, all reported white-collar employment; none, however, had worked for any of the potentially responsible parties (PRPs: the capacitor manufacturers responsible for contamination of the harbor). All reported having known of the pollution problem for at least three years. The responses of this group do not suggest a single most important source of information "concerning local events and controversies" (Question 7, public survey); however, television (including local-access cable), newspaper, conversation and town meetings are each seen as important by at least three-quarters of Group 1. This suggests a group of individuals who are well-informed, abtaining information through a variety of sources.

Group 2: Group 2 reported residency in the New Bedford area ranging from one-half year to 84 years, with a mean residency of approximately 38 years. Slightly more than 76\% of this Group reported having known of the harbor contamination for three years or more. Of those who chose to report employment status, $36 \%$ were not employed, $61 \%$ were employed by non-PRPs, and only $2.7 \%$ (2) reported employment 
by PRPs. Those who further described their employment were about evenly divided between blue and white-collar workers. Again, no single source of information "concerning local events and controversies" seemed most important: radio, television, and newspapers were all rated highly by this group. Predictably, in comparison with Group 1, far fewer Group 2 respondents considered public meetings to be an important source of information: $14.3 \%$ as opposed to $87.5 \%$ among Group 1 .

Group 3: Not a single Group 3. respondent was a resident of the New Bedford area. Reported period of involvement in environmental management ranged from 2 to 26 years, with a mean of approximately 13.4 years. When these individuals were asked how often they interacted with non-professionals during the course of their work, responses showed no clustering, ranging from "at least once a day" to a minimum of "once a month" or "varies too much to say." Asked to describe their role in site management, over half of these professionals $(62.5 \%)$ considered their primary role a managerial one; less than a third (28.5\%) rated the technical component of their work most important. None of the Group 3 managers considered "public information" to be the most important aspect of their work. Asked by means of a Likert scale whether public involvement in governmental environmental decisionmaking was, generally, "a help or a hindrance" (Question 6, professional survey), Group 3 
expressed cautious faith in citizen participation, favoring public involvement (mean response 7.33). Asked whether public involvement should be expanded within CERCLA's reauthorization (Question 7, professional survey), these managers were, again, cautiously positive (mean response $7.44)$.

Group 4: Only one of the seven Group 4 managers queried (approximately 14\%) had resided in the study area. Period of involvement in environmental management showed a range similar to that of Group 3 (5 to 33 years) and a similar mean ( 12.0 years). In contrast to the professionals of Group 3, almost half $(42.9 \%)$ of the Group 4 professionals reported being in contact with the public "at least once a day." Also unlike Group 3, over half the Group 4 professionals rated the technical component of their work most important (57.1\%); only one of the seven considered their managerial function most important (14.3\%), while one other (14.3\%) considered his or her public information capacity most important. Regarding the efficacy of public involvement in environmental decisionmaking (Question 6, professional survey), Group 4 agreed, essentially, with Group 3 (mean response 7.71); they were slightly less keen than Group 3, however, on the desirability of expanding public involvement in superfund (mean response 6.83). 


\section{B. Analytical approach.}

IV. B. 1. General methodology.

Results of each of the survey's thirty-three "core questions" (Questions 8-40, those which were administered to all four study groups) were examined in order to ascertain whether the hypothesized relationship was present. The reader will remember that the study's hypothetical model was one where:

1. The difference in perception between those groups which had participated in the facilitated discussions (Groups 1 and 3) was smaller than the difference between those which had not (Groups 2 and 4), but

2. Direction of differences separating citizens from managers remained constant; that is, the perceptions of the citizens (Groups 1 and 2) occupied one end of a continuum, while those of the managers (Groups 3 and 4 ) occupied the other.

This hypothetical relationship is diagrammed, once again, below.

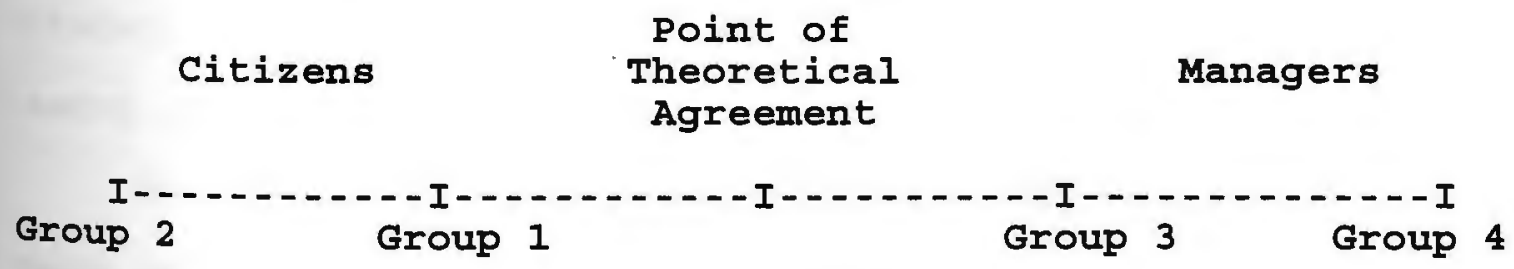

The results of each of the survey's 33 "core questions" were tested for the existence of this hypothetical relationship in two steps:

1. Tabulation of means and frequencies, using the SAS statistical package, and examination of these totals to determine whether the general relationship diagrammed above was apparent. 
2. Where the expected relationship was generally evident, statistical testing was undertaken in order to determine whether differences among groups were statistically significant.

In other words, if the graphic relationship expressed in the study's hypothetical model was initially discernable, and there were significant differences among the study groups, then the research hypothesis was accepted, and the null rejected. Where the graphic relationship of the hypothetical model was not evident, then, the null hypothesis could be accepted, and the research hypothesis rejected; questions which fell into this category were not initially examined for statistical significance.

\section{B. 2. Statistical approach: Likert-scale questions.}

In keeping with the methodology explained above, the first step involved a simple examination of the means of the Likert score by group for each question. Where the hypothetical relationship was initially apparent, the Student-t test was used to test for significant differences among group means.

Since Group 2's mean dominated the study's universal mean by virtue of Group 2's proportionally large $n\left(n_{2}=110\right.$ while $\mathbf{N}=134$ ), the three smaller groups were tested for divergence from the universal mean, $\mu$. Strictly speaking, the existence of statistically significant differences between each of the smaller groups and $\mu$ would not imply differences among the smaller groups (e.g., between 3 and 
4). However, in the context of the limitations imposed by the differences in size among the study groups, the relationship between $\mu$ and the three smaller groups (Groups 1,3 , and 4) was taken to be an indicator that the hypothetical relationship was present in some form. Conversely, the lack of such significant differences allowed the research hypothesis to be rejected, and the null accepted.

The formula for the student $t$ Test is as follows:

$$
t=\frac{X_{m e}-\mu}{s t d / \sqrt{n-1}}
$$

Where:

$$
\begin{aligned}
& t=\text { student } t \text { statistic. } \\
& \mathrm{x}_{\mathrm{me}}=\text { Mean for sample group (Group } 1,3 \text {, or } 4 \text { ). } \\
& \mu=\text { Mean for all groups, combined. } \\
& \mathbf{s t d}=\text { Standard deviation of sample group. } \\
& \mathrm{n}=\text { Size of sample group. } \\
& \mathrm{df}=\text { degrees of freedom }=\mathrm{n}-1
\end{aligned}
$$

(West 1993)

Blalock's (1979) table for the distribution of $t$ in a twotailed test was used to determine whether or not differences among groups were statistically significant at the 95 th percentile, i.e. $\alpha \leq .05$.

\section{B. 3. Statistical approach: Frequency-based responses.} The first step of hypothesis testing of the survey's checklist and rank-order responses, like that for the Likert-scale questions, involved simply examining the margin totals for each checklist or rank-order sub-question in order to determine whether the general hypothetical 
relationship was apparent. Where it was, statistical analysis of both these types of questions focused upon categorical frequencies. In the case of checklist questions, responses for each group were divided into two sub-groups based upon whether the respondent had checked a particular line (considered a "yes" response) or not (considered a "no"); non-respondents were omitted from analysis. For rank-order questions, the number of respondents who had assigned a specific rank to a particular sub-question was measured against those who had not. Following Siegel and Castellan (1988), the Chi-Square $\left(\mathrm{x}^{2}\right)$ test, corrected for continuity with the data cast into a $2 \times 2$ contingency table, was used to test for differences among groups. Again, the considerably larger $n$ of Group 2 required an asymmetrical approach to the testing. Response frequencies for each of the smaller groups were tested against those of the largest group (Group 2). Again, the existence of significant differences between each of the three smaller groups, and the larger group, was used as a general indicator, while the lack of such differences was considered to be evidence for acceptance of the null hypothesis. The mean was disregarded for this set of analyses.

The contingency table used for analysis is presented in Table 4.2. 
Table 4.2: Contingency table for $\mathrm{x}^{2}$ analysis of response frequencies.

\begin{tabular}{|l|c|c|}
\hline & Group 1, 3, or 4 & Group 2 \\
\hline Frequency "no" & Cell "A" & Cell "B" \\
\hline Frequency "Yes" & Cell "C" & Cell "D" \\
\hline
\end{tabular}

The formula for the $\mathrm{x}^{2}$ test corrected for continuity is as follows:

$$
X^{2}=\frac{n(|A D-B C|-n / 2)^{2}}{(A+B)(C+D)(A+C)(B+D)}
$$

where

$\mathbf{X}^{2}=$ chi-square statistic

$\mathbf{N}=$ total sample (both groups)

A, B, C, D = respective cell values

$\mathrm{df}=$ degrees of freedom $=1$

(Siegel and Castellan 1988)

Siegel and Castellan's (1988) $\mathbf{x}^{2}$ table was used to determine significance. Again, differences were considered

statistically significant at the 95th percentile ( $\boldsymbol{\alpha} \leq .05)$;

a chi-square statistic of 3.84 or greater was considered indicative of this level of significance (Siegel and

Castellan 1988). Siegel and Castellan suggest that sparsity rules only apply to a chi-square analysis where df $>1$; therefore, the study treated zero values like any other for purposes of analysis by means of the chi-square corrected for continuity. 


\section{C. Analysis.}

IV. C. 1. Analysis of Iikert-scale responses.

The hypothesized relationship was graphically apparent in only one of the study's Likert-scale questions: Question 8. Therefore, this was the only question where the student$t$ Test was used for hypothesis testing.

Question 8: Respondents were asked to what extent they thought the existing contamination of the Acushnet River was a health risk. Possible Likert-scale responses ranged from 0, "No current health risk," to 10, "Great current health risk." A score of 5 was marked "Moderate health risk." Results and analysis are summarized in Table 4.3.

Table 4.3: Survey Question 8 -- Analysis of results.

\begin{tabular}{|c|c|c|c|c|c|}
\hline & $\begin{array}{l}\text { Mean, } \\
\mathbf{x}_{\text {me }} \text { or } \mu \\
\end{array}$ & std & $\mathrm{n}$ or $\mathrm{N}$ & $t$ & $\begin{array}{l}\text { SS@ } \\
\alpha=.05 ?\end{array}$ \\
\hline Group 1 & 8.375 & 1.847 & 8 & 0.851 & no \\
\hline Group 2 & 7.561 & 2.250 & 82 & --- & --- \\
\hline Group 3 & 8.375 & 1.188 & 8 & 1.323 & no \\
\hline Group 4 & 9.000 & 1.826 & 7 & 1.635 & no \\
\hline All & 7.781 & 2.157 & 105 & --- & $\ldots$ \\
\hline
\end{tabular}

Since analysis did not suggest the existence of statistically significant differences (SSDs) among groups, the research hypothesis was rejected and the null accepted for Question 8. Since this was the only one of the study's Likert-scale questions which showed the hypothesized 
relationship graphically, the research hypothesis could be rejected for all the survey's Likert-scale questions.

\section{C. 2. Analysis of frequency-based responses.}

Examination of the survey's rank-order and checklist responses revealed that, as in the case of the Likert-scale responses, the hypothesized perceptual convergence of Groups 1 and 3 was not generally apparent. The response to only one checklist sub-question appeared to exhibit the hypothesized relationship; this was analyzed by means of the $\mathbf{x}^{2}$ test corrected for continuity.

Question 9f: Question 9 asked respondents to identify those groups whom they considered to be "at risk" from the contamination at the New Bedford Harbor Superfund Site. The question made use of a checklist describing fourteen different groupings of people, categorized primarily on the basis of age, race, and geography. The only one of these fourteen sub-questions where the hypothesized relationship was apparent was 9f, which listed "People who use boats." A summary of results and analysis, using the $x^{2}$ test to compare Groups 1, 3, and 4 with Group 2, is presented in Table 4.4. 


Table 4.4: Question 9f - Analysis of results.
\begin{tabular}{|c|l|l|l|l|l|l|c||}
\hline & $\begin{array}{l}\text { Freq } \\
\text { "no" }\end{array}$ & $\begin{array}{c}\text { Freq. } \\
\text { "Yes" }\end{array}$ & $\begin{array}{c}\% \\
\text { "Yes" }\end{array}$ & $\begin{array}{c}\text { Group } \\
\mathbf{n}\end{array}$ & $\begin{array}{c}\text { Anal. } \\
\mathbf{N}\end{array}$ & $\begin{array}{c}\mathbf{x}^{2} \\
\text { stat }\end{array}$ & $\begin{array}{c}\text { SS @ } \\
\alpha=.05\end{array}$ \\
\hline Group1 & 4 & 4 & $50.0 \%$ & 8 & 92 & 0.03 & no \\
\hline Group2 & 45 & 39 & $46.4 \%$ & 84 & -- & -- & - \\
\hline Group3 & 3 & 6 & $33.3 \%$ & 9 & 93 & 0.65 & no \\
\hline Group4 & 1 & 6 & $14.3 \%$ & 7 & 91 & 2.57 & no \\
\hline Al1 & -- & -- & -- & 108 & -- & -- & -- \\
\hline
\end{tabular}

On the basis of the chi-square test corrected for continuity, the research hypothesis was rejected and the null accepted for Question $9 f$.

\section{C. 3. Rejection of major hypothesis.}

The study's hypothetical relationship was graphically apparent in the results of only two of the survey's questions; therefore only these two (Questions 8 and $9 f$ ) were tested statistically. In neither case did statistical testing support $\mathrm{H}_{\mathrm{r}}$, which hypothesized the existence of statistically significant differences among groups. The research, therefore, rejected the major hypothesis, and in so doing, accepted the null. Participation in the facilitated discussions chaired by the Massachusetts office of Dispute Resolution does not appear to have caused the risk perceptions of citizens and managers, regarding the New Bedford Harbor Superfund Site, to converge. 


\section{D. An emergent relationship: Polarization.}

Examination of survey response margin totals exposed a relationship which appeared to be far more prevalent than the hypothesized one. This relationship may be described as polarization of perception, and is in fact nearly the opposite of the hypothetical relationship. Polarization of perception may be said to be present where Group 1 and Group 3, the facilitated discussion participants, are statistical outliers at either end of the study's perceptual continuum. schematically, this relationship may be represented as follows :

$\mathrm{x}_{\mathrm{me}}$, Group $1 \quad \mathrm{x}_{\mathrm{me}}$, Group 3
or Group 2 I

The null and research hypotheses may be stated as follows:

$\mathbf{H}_{0}$ : It is hypothesized that there are no statistically significant differences in the measured perceptions of the three groups, regarding the hazards associated with the New Bedford Harbor Superfund Site.

$\mathbf{H}_{\mathbf{r}}$ : It is hypothesized that there are statistically significant differences in the measured perceptions of the three groups, regarding the hazards associated with the New Bedford Harbor Superfund Site.

The sub-hypotheses used to test for polarization were as follows :

Sub-hypothesis 1: It is hypothesized that the perceptions of Group 1 and Group 3, regarding the hazards associated with the New Bedford Harbor Superfund Site and its remediation, lie at either extreme of the 
perceptual continuum formed by the perceptions of all four groups.

sub-hypothesis 2: It is hypothesized that the perceptions of Group 1, regarding the hazards associated with the New Bedford Harbor Superfund Site and its remediation, are different, to a statistically significant degree, from those of Group 2 (for frequency-based questions), or from the universal mean, $\mu$ (for Likert-scale questions).

Sub-hypothesis 3: It is hypothesized that the perceptions of Group 3, regarding the hazards associated with the New Bedford Harbor superfund Site and its remediation, are different, to a statistically significant degree, from those of Group 2 (for frequency-based questions), or from the universal mean, $\mu$ (for Likert-scale questions).

It will be noted that, again, $\mu$ and Group 2 were treated as, if not the same, similar for purposes of analysis, since the proportionally large $\mathrm{n}$ of Group 2 caused it to dominate the study's statistical universe.

The method for testing the polarization hypothesis was similar to that used to test the major hypothesis. Again, in order to validate the model, the research first examined margin totals for the existence of the general polarized relationship. Where this relationship was graphically apparent, statistical testing was undertaken to test for significant differences. Acceptance of the research hypothesis required SSDs between Group 1 and the mean (or its proxy, Group 2), as well as between Group 3 and the mean (or, again, Group 2). Though Group 4 was tested along with the other groups, its statistical status was in fact irrelevant to the search for polarization. 
of the three types of questions (Likert, checklist, and rank-order) used in the survey's "core" section, approximately $33 \%$ of Likert-scale questions ( 7 of 21 ), $24 \%$ of checklist sub-questions ( 9 of 38 ), and none of the rankorder sub-questions showed the general polarization relationship. Again, the student-t Test was used to analyze the results of the Likert-scale questions; the three smaller groups were each tested for significant differences against the universal mean, $\mu$, dominated by Group 2. If Group 1 and Group 3 each showed statistically significant differences from $\mu$, then the model was considered validated, and $\mathrm{H}_{\mathrm{r}}$ was accepted.

Once again, frequency-based questions (rank-order and checklist) were tested by means of the Chi-square test corrected for continuity. Each of the three smaller groups was compared, statistically, with Group 2; where Group 1 and 3 were both found to be statistically different from Group 2, $\mathrm{H}_{\mathrm{r}}$ was, again, accepted.

IV. D. 1. Analysis of Likert-scale responses: Polarization.

Question 13: Question 13 asked respondents to what extent they thought the government's scientists actually knew about the health risks related to the existing harbor contamination. 0 on the Likert scale was marked "They know very little;" 5 was marked "They know something;" 10 was 
marked "They know a great deal." Results and analysis are resented in Table 4.5 .

Table 4.5: Survey Question 13 -- Analysis of results.

\begin{tabular}{||l|l|l|l|l|c||}
\hline & $\begin{array}{l}\text { Mean, } \\
\mathbf{x}_{\text {me }} \text { or } \mu\end{array}$ & std & $\mathbf{n}$ or $\mathbf{N}$ & $t$ & $\begin{array}{c}\text { SS @ } \\
=.05 ?\end{array}$ \\
\hline Group 1 & 6.750 & 2.493 & 8 & 0.314 & no \\
\hline Group 2 & 6.988 & 2.809 & 85 & --- &.-- \\
\hline Group 3 & 7.889 & 1.269 & 9 & 1.879 & no \\
\hline Group 4 & 7.000 & 1.826 & 7 & 0.067 & no \\
\hline All & 7.046 & 2.630 & 109 & --- &.-- \\
\hline
\end{tabular}

Statistical analysis of Question 13 did not support the polarization model, since statistically significant differences were not demonstrated. The new research hypothesis was therefore rejected, and the null accepted, for Question 13 .

Question 16: Question 16 asked survey respondents their measure of the acceptability of incineration as a way of reducing the risks of the contaminated harbor. 0 on the Likert scale was marked "Completely unacceptable;" 5 was marked "Not sure;" and 10 was marked "Completely acceptable." The existence of a polarized relationship between Groups 1 and 3 was graphically apparent; however, the relatively large standard deviation for Group 1 prevented the use of the t-Test to test for significance of this group's responses. Results and analysis follow in Table 4.6 . 


Table 4.6: Survey Question 16 -- Analysis of results.
\begin{tabular}{||l|l|l|l|l|c||}
\hline & $\begin{array}{l}\text { Mean, } \\
\text { or } \mu\end{array}$ & std & n or N & $t$ & $\begin{array}{c}\text { SS @ } \\
=.05 ?\end{array}$ \\
\hline Group 1 & 2.500 & 4.071 & 8 & --- & --- \\
\hline Group 2 & 4.595 & 2.958 & 84 & --- & -- \\
\hline Group 3 & 8.556 & 1.590 & 9 & 6.737 & yes \\
\hline Group 4 & 4.571 & 3.552 & 7 & 0.136 & no \\
\hline All & 4.769 & 3.222 & 108 & --- & --- \\
\hline
\end{tabular}

The polarization model could not be demonstrated statistically; the only statistically valid difference evident was that between Group 3 and the statistical universe. The null was accepted.

Question 17: This question asked respondents to rate the risks of incinerating the contaminated harbor sediments, using a Likert scale whereon 0 was marked "High risk;" 5 was marked "Moderate risk;" and 10 represented "No risk." Once again, a polarized relationship between Groups 1 and 3 was graphically apparent. Since, however; the standard deviation for Groups 1 and 2 were larger than the means for those groups, the validity of statistical analysis using the parametric t-Test was called into question. Therefore, results alone follow in Table 4.7 . 
Table 4.7: Survey Question 17 -- Results.

\begin{tabular}{|c|c|c|c|c|c|}
\hline & $\begin{array}{l}\text { Mean, } x_{\text {me }} \\
\text { or } \mu\end{array}$ & std & $\mathbf{N}^{\mathbf{n}}$ or & $t$ & $\begin{array}{l}\text { SS @ } \\
\alpha=.05 ? \\
\end{array}$ \\
\hline Group 1 & 1.000 & 1.690 & 8 & $\ldots$ & $\ldots$ \\
\hline Group 2 & 2.917 & 2.909 & 84 & $\ldots$ & $\ldots$ \\
\hline Group 3 & 8.333 & 1.225 & 9 & -- & -- \\
\hline Group 4 & 3.286 & 2.289 & 7 & --- & --- \\
\hline All & 3.250 & 3.130 & 108 & -- & -- \\
\hline
\end{tabular}

Inferences of statistical significance could not be drawn from the results of Question 17; therefore, the null hypothesis was once again accepted.

Question 20: Question 20 asked respondents to what extent they thought the government's scientists actually knew about the health risks resulting from the proposed incineration of the harbor sediments. As in Question 13, 0 on the Likert scale was marked "They know very little;" 5 was marked "They know something;" 10 was marked "They know a great deal." Results and analysis are presented in Table 4.8 .

Table 4.8: Survey Question 20 -- Analysis of results.

\begin{tabular}{|l|l|l|l|l|c||}
\hline & $\begin{array}{l}\text { Mean, } \\
\text { or } \mu\end{array}$ & std & n or N & t & $\begin{array}{c}\text { SS @ } \\
=.05 ?\end{array}$ \\
\hline Group 1 & 5.000 & 2.726 & 8 & 0.435 & no \\
\hline Group 2 & 5.185 & 2.881 & 81 & --- &.-- \\
\hline Group 3 & 7.778 & 2.636 & 9 & 2.500 & yes \\
\hline Group 4 & 6.000 & 2.582 & 7 & 0.524 & no \\
\hline All & 5.448 & 2.892 & 105 &.-- & $-\ldots$ \\
\hline
\end{tabular}


Again, statistical analysis did not support the polarization model, but did demonstrate Group 3 to be a statistical outlier. The null hypothesis was accepted.

puestion 24: This question asked respondents what they thought would be the overall economic effect of USEPA's proposed incineration on the Greater New Bedford area. 0 on the Likert scale was marked "Harmful economic effect;" 5 was marked "No economic effect;" 10 was marked "Positive economic effect." Results and analysis are presented in Table 4.9.

Table 4.9: Survey Question 24 -- Analysis of results.

\begin{tabular}{||l|l|l|l|l|c||}
\hline & $\begin{array}{l}\text { Mean, } \\
\text { or } \mu\end{array}$ & std & n or N & $t$ & $\begin{array}{c}\text { SS @ } \\
=.05 ?\end{array}$ \\
\hline Group 1 & 3.000 & 1.690 & 8 & 3.117 & yes \\
\hline Group 2 & 5.120 & 2.795 & 83 & -- & -- \\
\hline Group 3 & 6.222 & 1.563 & 9 & 2.228 & no \\
\hline Group 4 & 4.143 & 1.215 & 7 & 1.710 & no \\
\hline Al1 & 4.991 & 2.644 & 107 & --- &.-- \\
\hline
\end{tabular}

The Student t-Test, applied to the results of Question 24, showed Group 1 to be statistically different from the mean, while Group 3 was not. The new research hypothesis was thus rejected, and the null accepted; the polarization model appeared not to apply in this instance.

Question 39: This question asked respondents whether a "proven ...technology" (Likert score = 10) or an "innovative... technology" (Likert $=0$ ) was preferable for 
cleaning up New Bedford Harbor, where a score of 5 indicated equal importance for the two extremes. Results and analysis are presented in Table 4.10.

Table 4.10: Survey Question 39 -- Analysis of results.

\begin{tabular}{||l|l|l|l|l|c||}
\hline & $\begin{array}{l}\text { Mean, } \\
\text { or } \mu\end{array}$ & std & n or N & $t$ & $\begin{array}{c}\text { SS @ } \\
=.05 ?\end{array}$ \\
\hline Group 1 & 4.875 & 1.885 & 8 & 1.098 & no \\
\hline Group 2 & 5.468 & 4.785 & 79 & --- & --- \\
\hline Group 3 & 7.444 & 1.590 & 9 & 3.179 & yes \\
\hline Group 4 & 6.500 & 2.820 & 6 & 0.668 & no \\
\hline All & 5.657 & 4.350 & 102 & --- & --- \\
\hline
\end{tabular}

The research hypothesis could not be supported, since only Group 3 could be shown to differ, statistically, from the universal mean; the polarization model did not apply to the results of Question 39. Incidentally, the relatively large standard deviation associated with Group 2 seemed to imply that the public was largely ambivalent regarding the need for a time-tested sediment clean-up technology.

Question 40: Question 40 asked respondents to compare the health risks stemming from the harbor contamination with those from the proposed incineration, using a Likert scale whereon 0 was marked "Incineration is greatest risk;" 5 was marked "Equal risks;" and 10 was marked "Existing contamination is greatest risk." Standard deviations and $\mu$ were too large to permit use of the t-Test; results alone are therefore presented in Table 4.11. 
Table 4.11: Survey Question 40 -- Results.

\begin{tabular}{|c|c|c|c|c|c|}
\hline & $\begin{array}{l}\text { Mean, } \mathbf{x}_{\mathrm{me}} \\
\text { or } \mu\end{array}$ & std & $\mathbf{n}$ or $\mathbf{N}$ & $t$ & $\begin{array}{l}\text { SS @ } \\
\alpha=.05 ? \\
\end{array}$ \\
\hline Group 1 & 2.875 & 3.482 & 8 & --- & --- \\
\hline Group 2 & 6.543 & 9.818 & 81 & --- & $\ldots$ \\
\hline Group 3 & 9.111 & 1.167 & 9 & $-\cdots$ & --- \\
\hline Group 4 & 7.500 & 3.332 & 6 & $\ldots$ & --- \\
\hline $\mathrm{All}$ & 6.538 & 8.833 & 104 & $\cdots$ & $\cdots$ \\
\hline
\end{tabular}

While no inferences may be drawn regarding statistical significance of the results of Question 40 , it may be noted that the standard deviation for groups 1 and 2 was quite large, while that for Group 3 was remarkably small. This seems to imply that the public remained deeply ambivalent about the relative risks of contamination versus incineration, whereas those Federal decisionmakers directly involved in the site had no doubt that incineration was far safer than forgoing cleanup of the contaminated harbor sediments.

IV. D. 2. Analysis of frequency-based responses: Polarization.

An examination of margin totals suggested that the results of a number of the survey's checklist questions might fit the polarization model. Where the polarized relationship was initially apparent, statistical analysis was undertaken using, once again, the $\mathbf{x}^{2}$ test corrected for continuity. 
Question 9: As mentioned earlier, Question 9 asked respondents to identify whom they considered to be "at risk" from the contamination at the New Bedford Harbor Superfund site by checking from a list of fourteen demographic and geographic categories. The polarization relationship appeared in the responses to three of these sub-questions:

Question 9b: Question 9b specified "Old people" as a possible category of individuals "at risk" from the harbor contamination. A summary of results and analysis, using the $\mathbf{x}^{2}$ test to compare Groups 1,3, and 4 with Group 2, is presented in Table 4.12 .

Table 4.12: Question 9b -- Analysis of results.

\begin{tabular}{||l|l|l|l|l|l|l|c||}
\hline & $\begin{array}{c}\text { Freq } \\
\text { "no" }\end{array}$ & $\begin{array}{c}\text { Freq. } \\
\text { "yes" }\end{array}$ & $\begin{array}{c}\% \\
\text { "yes" }\end{array}$ & $\begin{array}{c}\text { Group } \\
\mathbf{n}\end{array}$ & $\begin{array}{c}\text { Anal } \\
\mathrm{N}\end{array}$ & $\begin{array}{c}\mathbf{x}^{2} \\
\text { stat. }\end{array}$ & $\begin{array}{c}\text { SS@ } \boldsymbol{\alpha} \\
=.05\end{array}$ \\
\hline Group1 & 2 & 6 & 75 & 8 & 92 & 0.293 & no \\
\hline Group2 & 35 & 49 & 58.3 & 84 & -- & -- & -- \\
\hline Group3 & 4 & 5 & 55.6 & 9 & 93 & 0.038 & no \\
\hline Group4 & 3 & 4 & 57.1 & 7 & 91 & 0.114 & no \\
\hline Al1 & 44 & 64 & 59.3 & 108 & -- & -- & -- \\
\hline
\end{tabular}

Clearly, the null hypothesis could be accepted in the case of Question 9b: the polarized relationship was not statistically significant.

Question 9d: Question 9d asked respondents whether they considered themselves to be "at risk" from the harbor 
contamination. Results and analysis are presented in Table 4.13 .

Table 4.13: Question 9d-- Analysis of results.

\begin{tabular}{||l|l|l|l|l|l|l|c||}
\hline & $\begin{array}{l}\text { Freq. } \\
\text { "no" }\end{array}$ & $\begin{array}{l}\text { Freq. } \\
\text { "yes" }\end{array}$ & $\begin{array}{c}\% \\
\text { "yes" }\end{array}$ & $\begin{array}{c}\text { Group } \\
\mathbf{n}\end{array}$ & $\begin{array}{c}\text { Anal. } \\
\mathbf{N}\end{array}$ & $\begin{array}{l}\mathbf{x}^{2} \\
\text { stat. }\end{array}$ & $\begin{array}{l}\text { Ss @ } \\
\alpha=.05\end{array}$ \\
\hline Group1 & 3 & 5 & 62.5 & 8 & 92 & 0.013 & no \\
\hline Group2 & 39 & 45 & 53.6 & 84 & -- & -- & -- \\
\hline Group3 & 8 & 1 & 11.1 & 9 & 93 & 4.287 & yes \\
\hline Group4 & 5 & 2 & 28.6 & 7 & 91 & 0.771 & no \\
\hline Al1 & 55 & 53 & 49.1 & 108 & -- & -- & - \\
\hline
\end{tabular}

Since the response of only one of the three smaller groups showed a statistically significant difference from that of the large random sample (Group 2), the null hypothesis was once again accepted: it was concluded that the polarization model did not apply to the results of Question $9 \mathrm{~d}$. However, Group 3 was, once again, demonstrated to be a statistical outlier.

Question 9m: Question $9 \mathrm{~m}$ asked respondents whether they considered "All residents of Dartmouth" to be "at risk" from the sediment contamination. Results and analysis are presented in Table 4.14 . 


\begin{tabular}{|c|c|c|c|c|c|c|c|}
\hline & $\begin{array}{l}\text { Freq } \\
\text { "no" }\end{array}$ & $\begin{array}{l}\text { Freq. } \\
\text { "yes" }\end{array}$ & $\begin{array}{c}\frac{\circ}{6} \\
\text { "yes" }\end{array}$ & $\begin{array}{c}\text { Group } \\
\mathbf{n}\end{array}$ & $\begin{array}{c}\text { Anal. } \\
\mathbf{N}\end{array}$ & $\begin{array}{c}\mathbf{x}^{2} \\
\text { stat }\end{array}$ & $\begin{array}{l}\text { SS@Q } \\
=.05\end{array}$ \\
\hline Group1 & 2 & 6 & 75 & 8 & 92 & 3.80 & no \\
\hline Group2 & 56 & 28 & 33.3 & 84 & -- & -- & -- \\
\hline Group 3 & 8 & 1 & 11.1 & 9 & 93 & 0.98 & no \\
\hline Group4 & 6 & 1 & 14.3 & 7 & 91 & 0.38 & no \\
\hline All & 72 & 36 & 33.3 & 108 & -- & -- & -- \\
\hline
\end{tabular}

The lack of statistically significant differences among group responses to Question $9 \mathrm{~m}$ required that the null hypothesis be accepted in this instance.

Question 10: Question 10 asked respondents to choose from a list of nine ailments in order to express what they considered to be "the health risks of the current contamination." The responses to two of these nine subquestions appeared to fit the polarization model; thus statistical testing, summarized in the tables below, was undertaken.

Question 10a: Question 10a presented "Cancer" as a possible risk of the harbor contamination. Results and analysis appear in Table 4.15 . 
Table 4.15: Question 10a -- Analysis of results.

\begin{tabular}{||l|l|l|l|l|l|l|c||}
\hline & $\begin{array}{l}\text { Freq. } \\
\text { "no" }\end{array}$ & $\begin{array}{l}\text { Freq. } \\
\text { "yes" }\end{array}$ & $\begin{array}{c}\% \\
\text { "yes" }\end{array}$ & $\begin{array}{c}\text { Group } \\
\mathbf{n}\end{array}$ & $\begin{array}{c}\text { Anal. } \\
\mathbf{N}\end{array}$ & $\begin{array}{c}\mathrm{x}^{2} \\
\text { stat. }\end{array}$ & $\begin{array}{c}\text { SS @ } \\
\boldsymbol{\alpha}=.05\end{array}$ \\
\hline Group1 & 2 & 5 & 71.4 & 7 & 87 & 0.01 & no \\
\hline Group2 & 18 & 62 & 77.5 & 80 & -- & -- & -- \\
\hline Group3 & 0 & 9 & 100 & 9 & 89 & 1.34 & no \\
\hline Group4 & 1 & 6 & 85.7 & 7 & 87 & .0007 & no \\
\hline Al1 & 21 & 82 & 79.6 & 103 & -- & -- & - \\
\hline
\end{tabular}

The null hypothesis was accepted in this instance, as a result of the lack of statistically significant differences among group responses.

Question 10c: Question 10c listed "Respiratory problems" as a possible risk of the harbor contamination. Results and analysis are presented in Table 4.16.

Table 4.16: Question 10c -- Analysis of results.

\begin{tabular}{|c|l|l|l|l|l|c|c||}
\hline \hline & $\begin{array}{c}\text { Freq } \\
\text { "no" }\end{array}$ & $\begin{array}{l}\text { Freq. } \\
\text { "yes" }\end{array}$ & $\begin{array}{c}\% \\
\text { "yes" }\end{array}$ & $\begin{array}{c}\text { Group } \\
\mathbf{n}\end{array}$ & $\begin{array}{c}\text { Anal. } \\
\mathbf{N}\end{array}$ & $\begin{array}{c}\mathbf{x}^{2} \\
\text { stat }\end{array}$ & $\begin{array}{c}\text { SS @ } \\
\alpha=.05\end{array}$ \\
\hline Group1 & 1 & 6 & 85.7 & 7 & 87 & 0.15 & no \\
\hline Group2 & 23 & 57 & 71.2 & 80 & -- & -- & -- \\
\hline Group3 & 7 & 2 & 22.2 & 9 & 89 & 6.65 & yes \\
\hline Group4 & 4 & 3 & 42.9 & 7 & 87 & 1.28 & no \\
\hline Al1 & 35 & 68 & 66.0 & 103 & -- & -- & -- \\
\hline
\end{tabular}

Again, the research hypothesis was rejected, and the null accepted, due to the lack of significant differences among group responses to Question 10c. Group 3 was once again the sole statistical outlier. 
Question 11f: Question 11 utilized a checklist naming six possible pathways to ask respondents how health risks might be transferred from the Superfund site to the population. of the six sub-questions, only one appeared to support the polarized relationship: sub-question llf, which referred to "Eating garden vegetables." Results and analysis appear in Table 4.17 .

Table 4.17: Question 11f -- Analysis of results.

\begin{tabular}{|c|l|l|c|c|c|c|c||}
\hline & $\begin{array}{l}\text { Freq. } \\
\text { "no" }\end{array}$ & $\begin{array}{c}\text { Freq. } \\
\text { "yes" }\end{array}$ & $\begin{array}{c}\% \\
\text { "yes" }\end{array}$ & $\begin{array}{c}\text { Group } \\
\mathbf{n}\end{array}$ & $\begin{array}{c}\text { Anal. } \\
\mathbf{N}\end{array}$ & $\begin{array}{c}\mathbf{X}^{2} \\
\text { stat. }\end{array}$ & $\begin{array}{c}\text { SS @ } \\
\boldsymbol{\alpha = . 0 5}\end{array}$ \\
\hline Group1 & 5 & 3 & 37.5 & 8 & 92 & 0.122 & no \\
\hline Group2 & 53 & 31 & 36.9 & 84 & -- & -- & -- \\
\hline Group3 & 8 & 1 & 11.1 & 9 & 93 & 1.39 & no \\
\hline Group4 & 6 & 1 & 14.3 & 7 & 91 & 0.628 & no \\
\hline Al1 & 72 & 36 & 33.3 & 108 & -- & -- & -- \\
\hline
\end{tabular}

The null hypothesis was once again accepted for the results of Question $11 f$.

Question 26: This question offered respondents a checklist of eight possible outcomes of the government's clean-up of New Bedford Harbor, asking them which results they would prefer. Three of the sub-questions which appeared to show the polarized relationship were tested for significance; analysis and results are summarized in the following tables.

Question 26a: This sub-question asked whether respondents would like to see the "Clean-up...provide jobs." 


\begin{tabular}{|c|c|c|c|c|c|c|c|}
\hline & $\begin{array}{l}\text { Freq. } \\
\text { "no" }\end{array}$ & $\begin{array}{l}\text { Freq. } \\
\text { "yes" }\end{array}$ & $\begin{array}{c}\frac{\circ}{0} \\
\text { "yes" }\end{array}$ & $\begin{array}{c}\text { Group } \\
\mathbf{n}\end{array}$ & $\begin{array}{c}\text { Anal } \\
\mathbf{N}\end{array}$ & $\begin{array}{c}\mathbf{x}^{2} \\
\text { stat. }\end{array}$ & $\begin{array}{l}S S @ \\
\alpha=.05\end{array}$ \\
\hline Group1 & 2 & 6 & 75 & 8 & 90 & 0.154 & no \\
\hline Group2 & 20 & 62 & 75.6 & 82 & -- & -- & -- \\
\hline Group 3 & 7 & 2 & 22.2 & 9 & 91 & 8.667 & yes \\
\hline Group4 & 1 & 5 & 83.3 & 6 & 88 & 0.005 & no \\
\hline All & 30 & 75 & 71.4 & 105 & -- & -- & -- \\
\hline
\end{tabular}

The null hypothesis was once again accepted; again, Group 3 appeared as a statistical outlier.

Question 26c: This sub-question put forth "restore commercial options of harbor" as a clean-up result.

Table 4.19: Question 26c -- Analysis of results.

\begin{tabular}{|c|l|l|l|l|l|l|c||}
\hline & $\begin{array}{l}\text { Freq. } \\
\text { "no" }\end{array}$ & $\begin{array}{l}\text { Freq. } \\
\text { "yes" }\end{array}$ & $\begin{array}{c}\% \\
\text { "yes" }\end{array}$ & $\begin{array}{c}\text { Group } \\
\mathbf{n}\end{array}$ & $\begin{array}{c}\text { Anal. } \\
\mathbf{N}\end{array}$ & $\begin{array}{c}\mathbf{x}^{2} \\
\text { stat. }\end{array}$ & $\begin{array}{c}\text { SS @ } \\
\boldsymbol{\alpha}=.05\end{array}$ \\
\hline Group1 & 1 & 7 & 87.5 & 8 & 90 & 0.009 & no \\
\hline Group2 & 17 & 65 & 79.3 & 82 & -- & -- & -- \\
\hline Group3 & 4 & 5 & 55.6 & 9 & 91 & 1.41 & no \\
\hline Group4 & 0 & 6 & 100 & 6 & 88 & 0.498 & no \\
\hline Al1 & 22 & 83 & 79.0 & 105 & -- & -- & -- \\
\hline
\end{tabular}

Due to the inability of the analysis to show statistical differences between the study groups and the universal mean, the research hypothesis was rejected, and the null accepted, for Question $26 \mathrm{C}$.

Question 26e: This sub-question asked whether respondents would like to see the clean-up "enhance tourism." 


\begin{tabular}{|c|c|c|c|c|c|c|c|}
\hline & $\begin{array}{l}\text { Freq. } \\
\text { "no" }\end{array}$ & $\begin{array}{l}\text { Freq. } \\
\text { "yes" }\end{array}$ & $\begin{array}{c}\frac{\circ}{\sigma} \\
\text { "yes" }\end{array}$ & $\begin{array}{c}\text { Group } \\
\mathbf{n}\end{array}$ & $\begin{array}{c}\text { Anal. } \\
\mathbf{N}\end{array}$ & $\begin{array}{c}\mathbf{x}^{2} \\
\text { stat. }\end{array}$ & $\begin{array}{l}S S @ \\
\alpha=.05\end{array}$ \\
\hline Groupl & 3 & 5 & 62.5 & 8 & 90 & 0.030 & no \\
\hline Group2 & 39 & 43 & 52.4 & 82 & -- & -- & -- \\
\hline Group3 & 7 & 2 & 22.2 & 9 & 91 & 1.877 & no \\
\hline Group4 & 2 & 4 & 66.6 & 6 & 88 & 0.063 & no \\
\hline All & 51 & 54 & 51.4 & 105 & -- & -- & -- \\
\hline
\end{tabular}

Again, the research hypothesis was rejected, and the null accepted, for Question 26e, since none of the differences between groups proved significant.

As a result of the foregoing analyses, it was concluded that the polarization model was not present to a statistically significant degree in any of the survey's checklist questions. Nor was polarization discernable in the responses to any of the survey's rank-order questions.

IV. D. 3. Summary of analysis: Polarization.

Though initially apparent in $33 \%$ of the study's core Likert-scale questions, the polarization model was not statistically demonstrable in this category of question. Of the six Likert-scale questions which were analyzed statistically, however, Group 3, the manager-participants, proved to be a statistical outlier in three instances (50\%).

Though initially apparent in $23.7 \%$ of the study's checklist sub-questions, statistical analysis failed to demonstrate existence of the polarization model for this category of question, as well. Of the ten checklist sub- 
questions analyzed statistically, Group 3 was a statistical outlier in $33 \%$ of cases ( 3 of 10 ).

The polarized relationship was not discernable in any of the study's rank-order questions. 


\section{E. Trust in government and expectation of benefits.}

Besides looking at perceptions of risk regarding the New Bedford Harbor Superfund Site and its remediation, the survey attempted to measure respondents' degree of trust in government, expectation of benefits resulting from the Superfund clean-up, and degree of knowledge regarding the pource of funds for the remediation. With two exceptions (Questions 13 and 20, discussed above), the responses to questions pertaining to these issues supported neither the hypothesized relationship nor the polarization model; thus they were omitted from the foregoing analysis. In order, however, to complete the study, and to gain the most thorough understanding of respondents' perceptions regarding the New Bedford Harbor Superfund Site, this group of questions was subjected to the same statistical analysis as was used for the study's other Likert-scale questions. This step was undertaken in order to determine whether the smaller groups, ( 1,3 , and 4) differed from the universal mean, dominated by the public random sample (Group 2).

IV. E. 1. Trust in government decisionmaking.

Question 13: Respondents were asked to what extent they thought the government's scientists actually knew about the health risks stemming from the existing harbor contamination. Question 13 was discussed above; results and 
analysis were presented in Table 4.5 ; no SSDs were demonstrable.

Question 20: Survey participants were asked how much they thought USEPA's scientists "really [knew]" about the health risks of the proposed incineration. Question 20 was discussed above, and a summary of response and analysis presented (Table 4.8). Only Group 3 was statistically different from the universal mean.

Question 21: Participants were asked "to what extent" they thought USEPA "[told] the public the truth" about the risks of incineration. The question utilized a Likert scale, where 0 was labelled "They tell very little of the truth;" 5 was marked "They tell some of the truth," and 10 represented "They tell the truth 100\%." Results and analysis are summarized in Table 4.21.

Table 4.21: Survey Question 21 -- Results and analysis.

\begin{tabular}{||l|l|l|l|c|c||}
\hline & $\begin{array}{l}\text { Mean, } \\
\text { or } \mu\end{array}$ & std & n or N & t & $\begin{array}{c}\text { SS @ } \\
=.05 ?\end{array}$ \\
\hline Group 1 & 4.625 & 1.768 & 8 & 0.548 & no \\
\hline Group 2 & 4.329 & 2.807 & 82 & -- & -- \\
\hline Group 3 & 9.333 & 0.707 & 9 & 17.371 & yes \\
\hline Group 4 & 7.571 & 1.813 & 7 & 3.486 & yes \\
\hline All & 4.991 & 2.987 & 106 & -- & -- \\
\hline
\end{tabular}

Statistical analysis suggested that both professional groups ( 3 and 4 ) were statistically dissimilar from the public 
random sample (Group 2), while the citizen-participants were not.

Question 23: This question asked survey participants how well USEPA was working to protect the public health with respect to the New Bedford Harbor Superfund. The Likert scale equated a value of 0 with "A poor job;" 5 with "An O.K. job;" and 10 with "An excellent job." Results and analysis follow in Table 4.22 .

Table 4.22: Survey Question 23 -- Results and analysis.

\begin{tabular}{|c|l|l|l|l|c||}
\hline & $\begin{array}{l}\text { Mean, } \\
\text { or } \mu\end{array}$ & std & n or $\mathrm{N}$ & $\mathrm{t}$ & $\begin{array}{c}\text { SS @ } \\
=.05 ?\end{array}$ \\
\hline Group 1 & 4.750 & 1.752 & 8 & 1.380 & no \\
\hline Group 2 & 3.099 & 2.107 & 81 & -- & -- \\
\hline Group 3 & 7.750 & 2.659 & 8 & 3.894 & yes \\
\hline Group 4 & 6.857 & 1.952 & 7 & 3.021 & yes \\
\hline All & 3.836 & 2.581 & 104 & -- & -- \\
\hline
\end{tabular}

In this instance, analysis showed that the professional groups each differed, statistically, from the public random sample, while the citizen-participant group (Group 1) did not.

IV. E. 2. Expectation of benefits from clean-up.

Question 22: An attempt was made to gauge respondents' expectation of benefits resulting from the superfund cleanup of the Acushnet by asking "how clean, and how safe" respondents expected the river to be when the clean-up was 
complete. The question used a Likert scale on which 0 was marked "As dirty and unsafe as before;" 3.5 was marked "Safe for swimming;" 7.5 was marked "Fish will be edible;" and 10 was marked "Shellfish will be edible." Response and analysis are summarized in Table 4.23 .

Table 4.23: Survey Question 22 -- Results and analysis.

\begin{tabular}{||l|l|l|l|c|c||}
\hline & $\begin{array}{l}\text { Mean, } \mathbf{x}_{\mathrm{me}} \\
\text { or } \mu\end{array}$ & std & $\mathbf{n}$ or $\mathbf{N}$ & $\mathbf{t}$ & $\begin{array}{c}\text { SS @ } \\
\boldsymbol{\alpha}\end{array}$ \\
\hline Group 1 & 3.500 & 1.512 & 8 & 0.247 & no \\
\hline Group 2 & 3.562 & 2.903 & 80 & -- & -- \\
\hline Group 3 & 5.250 & 2.712 & 8 & 1.570 & no \\
\hline Group 4 & 2.857 & 2.410 & 7 & 0.797 & no \\
\hline All & 3.641 & 2.790 & 103 & -- & -- \\
\hline
\end{tabular}

In this instance, no statistical differences could be discerned among groups.

Question 29: A different approach to measuring respondents' expectations of superfund clean-up benefits was used in Questions 29 and 30, each of which asked a willingness-topay question regarding the harbor clean-up. Question 29 asked respondents how much they would "personally" be willing to pay to be sure that the Acushnet would be restored to a state where "fish and shellfish were safe to eat, and the river was safe for children to swim in." A Likert scale divided into ten increments was provided; these were marked with dollar values ranging from 0 to "Over $\$ 1000 . "$ Standard deviations were generally too large to 
permit the use of the student-t test; therefore, results alone are presented in Table 4.24 .

Table 4.24: Survey Question 29 -- Results.

\begin{tabular}{||l|l|l|l|c|c||}
\hline & $\begin{array}{l}\text { Mean, } \\
\text { or } \mu\end{array}$ & std & n or $\mathbf{N}$ & t & $\begin{array}{l}\text { SS @ } \\
=.05 ?\end{array}$ \\
\hline Group 1 & 683.33 & 376.39 & 6 & -- & -- \\
\hline Group 2 & 186.90 & 318.98 & 79 & -- & -- \\
\hline Group 3 & 116.67 & 68.31 & 6 & -- & -- \\
\hline Group 4 & 428.57 & 419.18 & 7 & -- & -- \\
\hline All & 230.25 & 343.65 & 98 & -- & -- \\
\hline
\end{tabular}

In spite of the study's inability to use statistical methods in this instance, strong differences in mean willingness-topay by group were readily apparent. The citizen-

participants (Group 1) placed the highest value, by far, on a pristine Acushnet; non-participant managers (Group 4) also valued such an outcome highly. Notably, the managers who participated in the facilitated discussions, Group 3, placed the lowest value upon a pristine Acushnet, a mere $17 \%$ of Group $1^{\prime}$ s valuation; Group 3's valuation amounted to only $62.4 \%$ of that of the New Bedford Area's relatively poor public, as represented by the study's stratified random sample (Group 2).

Question 30: This question was similar to Question 29, and used an identical Likert scale, graduated from 0 to "Over \$1000." Unlike the preceding question, however, Question 30 posited a scenario where the river was "no longer highly contaminated, but still not safe enough to swim or fish." 
Again, due to large standard deviations, results are expressed in Table 4.25 without test results.

Table 4.25: Survey Question 30 -- Results and analysis.

\begin{tabular}{|c|l|l|l|c|c||}
\hline & $\begin{array}{l}\text { Mean, } \\
\text { or } \mu\end{array}$ & std & n or N & $t$ & $\begin{array}{c}\text { SS @ } \\
\alpha .05 ?\end{array}$ \\
\hline Group 1 & 391.67 & 471.61 & 6 & -- & -- \\
\hline Group 2 & 26.71 & 45.91 & 80 & -- & -- \\
\hline Group 3 & 50.00 & 31.62 & 6 & -- & -- \\
\hline Group 4 & 181.43 & 220.79 & 7 & -- & - \\
\hline All & 61.18 & 157.42 & 99 & -- & -- \\
\hline
\end{tabular}

Again, large differences between group means were apparent, in spite of the inappropriateness of statistical analysis to this set of responses. In this instance, however, the public random sample (Group 2) least valued the posited outcome.

Within each group, there seemed to be a large difference between the value placed on the Question 29 scenario, and that associated with Question 30 's hypothetical situation, though here, too, statistical confirmation was not possible. For Group 1, a cleaner river was worth $57 \%$ of what the pristine river was worth; for Group 2, the figure was less than 15\%; and for both Group 3 and Group 4, the proportion was approximately $43 \%$.

IV. E. 3. Rnowledge of source of funds.

The last survey question for which responses were examined attempted to discern to what extent respondents were aware of the sources of funding of the superfund clean- 
up. As mentioned in an earlier section, corporations responsible for the contamination of New Bedford Harbor (potentially responsible parties: PRPs) have agreed to contribute $\$ 110$ million toward the clean-up, although Superfund itself provided federal monies for the initial investigations and planning, cost-recovery actions, etc.

Question 28: Respondents were asked, simply, "Who will pay for this [Superfund] cleanup?" Written responses were divided into two sub-groups: those which recognized the contribution of the PRPs, versus those which expressed a belief that "government" or "the taxpayer" would bear the entire burden. Statistical testing for differences among groups was then undertaken in the same manner as for all other frequency-based responses, using the Chi-Square $\left(\mathbf{X}^{2}\right)$ test corrected for continuity and cast into a $2 \times 2$ contingency table. Results and analysis are summarized in Table 4.26 .

Table 4.26: Question 28 - Results and analysis.

\begin{tabular}{|c|l|l|l|l|l|l|c||}
\hline & $\begin{array}{c}\text { Freq. } \\
\text { "Tax" }\end{array}$ & $\begin{array}{c}\text { Freq. } \\
\text { "PRP" }\end{array}$ & $\begin{array}{c}\% \\
\text { "PRP" }\end{array}$ & $\begin{array}{c}\text { Group } \\
\mathrm{n}\end{array}$ & $\begin{array}{c}\text { Anal. } \\
\mathrm{N}\end{array}$ & $\begin{array}{c}\mathrm{x}^{2} \\
\text { stat. }\end{array}$ & $\begin{array}{c}\text { SS @ } \\
\boldsymbol{\alpha}=.05\end{array}$ \\
\hline Group1 & 1 & 6 & 85.7 & 7 & 68 & 6.981 & yes \\
\hline Group2 & 44 & 17 & 27.9 & 61 & -- & -- & -- \\
\hline Group3 & 0 & 9 & 100 & 9 & 70 & 14.52 & yes \\
\hline Group4 & 1 & 4 & 80.0 & 5 & 66 & 3.635 & no \\
\hline Al1 & 46 & 36 & & & -- & -- & -- \\
\hline
\end{tabular}


In this instance, the response of Group 3, like that of Group 1, differed significantly from the response of Group 2. It is notable that a large majority of the public random sample, Group 2, expressed a lack of knowledge of the most important source of funding for remediation of the New Bedford Harbor superfund Site. 


\section{v. Conclusions.}

\section{v. A. Major hypothesis.}

The research has not supported the major hypothesis. The study has concluded, therefore, that the facilitated discussions held by the Massachusetts Office of Dispute Resolution did not result in the convergence of risk perceptions of citizens and managers regarding the New Bedford Harbor Superfund Site. On the basis of the literature survey, the study had defined such a convergence as a measure of the discussions' effectiveness in resolving conflict at the site. In other words, the study showed that the facilitated discussions were not effective, within the definition of effectiveness adopted by the study.

This conclusion stands in contrast to the study's initial, implicit assumption that the discussions were indeed effective in resolving conflict at the New Bedford Harbor Superfund site. It forces, therefore, a reassessment of this assumption. A re-examination of the course of events at the site, in light of the knowledge that perceptions between citizens and managers did not converge, suggests that the facilitated discussions did not resolve conflict at the New Bedford Harbor Superfund site.

As a result of the communication which took place within the discussions, prolonged legal action was clearly averted, and USEPA abandoned its plans to incinerate the Hot Spot sediments. However, at the time of this writing, 
citizens and managers have yet to agree upon a specific treatment method for the contaminated harbor sediments. The agreement to study the problem and search for alternative treatment technologies has placated the citizen activists and apparently given USEPA a sense that the cleanup is pomehow moving forward. But until citizens and planners agree upon a treatment method, a solution has not been found.

In short, the citizens won, defeating the incineration proposal through the medium of the facilitated discussions, in spite of the lack of acceptable alternatives. As the study has shown, it would have been most difficult for them to achieve a comparable result by means of legal action. To the extent the discussions have succeeded in averting conflict, then, they seem to have done so by effectively democratizing USEPA's Superfund decisionmaking process. And yet, when a plan which is years in the making is rejected in spite of the lack of clear alternatives, one is left with little wonder that superfund has been found to be among the least cost-effective of Federal environmental laws.

Having rejected its major hypothesis as well as an implicit, but fundamental, assumption, it remains for this study to examine the survey data more descriptively, in an effort to understand the nature of the conflict over remediation and the workings of the facilitated discussions within the context of public perceptions of the New Bedford Harbor superfund site. 


\section{v. B. Discussion of other findings.}

\section{B. 1. Polarization.}

Upon examination of means and frequencies of responses to the survey's core questions, it appeared that a polarization of perception between citizens and managers engaged in the facilitated discussions might be demonstrable. Statistical analysis, however, failed to support the existence of this model. Polarization was graphically apparent, if not statistically demonstrable, in 16 of the survey's 33 core questions (48\%). While the necessarily small $\mathrm{n}$ of three of the four study groups limited the ability of the statistical analyses to distinguish subtler differences among groups, the graphic prevalence of the polarization model suggests that it has some meaning in describing the relationship among the study groups.

If polarization of perceptions among citizens and managers exists to some degree, the relationship offers an explanation for the discussions' ability to avert, without resolving, conflict at the New Bedford Harbor Superfund site. The discussions appear to have engaged those groups holding the most intense views on either side of the controversy. By bringing these diametrically opposed groups to the table, the discussions brought them out of the public fora--courtrooms, newspapers, and City Hall. And yet, these 
groups--in fact a very small number of people--were those least likely to ultimately agree to a specific solution.

The involvement of those citizens with the most vehement views about incineration would seem to be the direct result of the Office of Dispute Resolution's inclusive approach to choosing discussion participants. In contrast, the earlier citizens' group, the New Bedford Community Work Group, appointed by the city's mayor, satisfied CERCLA's public involvement provisions without involving the citizens' groups which were most opposed to USEPA's incineration plans. To the extent, then, that the polarization relationship may exist, it seems to suggest that, by the time the facilitated discussions began, a chasm of perception had developed between a small group of citizens and the federal decisionmakers, regarding the harbor superfund site. Arguably, the foundation of the conflict over remediation of the New Bedford Harbor Superfund site was laid at the outset of the CERCLA public participation process, when USEPA and the City organized a citizens' advisory group which failed to involve the most passionate critics of the proposed incineration. This is an attractive conclusion, intuitively appealing; yet it must be regarded cautiously due to the inability of the study to show that the polarized relationship between citizens and managers involved in the facilitated discussions existed to a statistically significant degree. 


\section{v. B. 2. Group 3 as statistical outlier.}

In its analyses of differences in risk perception among the study groups, the study discovered only one trend for which statistical significance could be substantiated. This relationship showed Group 3 (the manager-participants) to be a statistical outlier: different from the study's universal mean (for Likert-scale questions) or from Group 2 (frequency-based responses). In 6 of the study's 11 analyses of Likert-scale questions (54\%), Group 3 was a statistical outlier; in 4 of these instances (35\%) it was the sole outlier. In 4 of the study's 11 analyses of frequency-based questions (35\%), Group 3 was a statistical outlier; in two of these cases (10\%) it was the sole outlier.

Questions where Group 3 was a statistical outlier dealt with a diversity of issues, including the risks of the contamination (Questions 9d, 10c), the risks of the incineration (Question 16), the goals and methods of the clean-up (Questions 39 and 26a), and degree of trust in government (Questions 20,21, and 23). The divergence of the manager-participants' perceptions from those of the public suggests two types of communicative failures on the part of the government decisionmakers: failure to communicate the risks of the site and the goals of the clean-up to the clean-up's natural constituency, and failure to incorporate the ideals of the community regarding the cleanup into their own views of the situation. The goals of 
a Superfund cleanup are largely fixed by the law itself. However, if site managers expect the support of a community, they must communicate the benefits of those goals, and, where possible, craft an implementation plan which works toward satisfying community goals to the extent possible while meeting the requirements of the law.

Perhaps the most interesting of these results are those which show the perceptions of the Group 3 managers to be the sole statistical outlier. Here, the perceptions of the finager-participants differ not only from those of the citizens' groups but from those of the resource managers who did not participate in the facilitated discussions. This suggests that Group 3's perceptual differences do not stem solely from their professional orientation, but also from the process of their involvement in decisionmaking, conflict and dialogue at the Superfund site.

\section{v. B. 3. Trust in government.}

The study found that the public groups shared a relatively low degree of trust in the ability of the overnment to determine and deal with the problems arising from the contamination and its remediation. Responses to Question 13 (Table 4.5) reflected cautious optimism concerning the government's knowledge of the risks of the site. However, when asked how much the government's scientists knew about the risks of the incineration (Question 20, Table 4.8), mean Likert response of the public 
groups (Groups 1 and 2) rested at approximately 5, or "They know something," where 10 represented "They know a great deal." Asked to what extent the government decisionmakers "[told] the public the truth" about the risks of incineration (Question 21, Table 4.21), mean response for both public groups was even lower, in the 4.5 range, near "They tell some of the truth."

A finding, in 1994, of lack of trust in government among the public will surprise no one. However, this, too, sheds light on the source of the controversy over remediation of the New Bedford. Harbor superfund site. If citizens do not believe that the government can, or will, accurately assess and communicate the risks attending its environmental decisionmaking, they have no reason to support it. As rational actors under such circumstances, they will "take the devil they know," or think they know (the contaminated harbor) over the one that they do not (incineration). 


\section{B. 4. Expectation of benefits.}

Three of the survey's questions $(22,29$, and 30$)$ examined respondents' expectation of benefits from the harbor clean-up. While analysis of question 22 (Table 4.23) found the response of Group 3 to be significantly higher than that of the other groups, no group felt that fish in the harbor, after clean-up, would be safe to eat; Group 2 expected the harbor to be just safe enough for swimming (mean Likert score $=3.6)$. Clearly, public expectation of water quality improvement as a result of the superfund project was low.

Perhaps a more insightful measure of public expectation of benefits of the site is revealed by the comparison of responses to Questions 29 and 30 (Tables 4.24 and 4.25). Group 2 valued a pristine Acushnet at $\$ 186.90$, compared with $\$ 26.71$ for a cleaner, but not useable, river. This sevenfold difference is indicative, again, of low public expectation of benefit resulting from the superfund cleanup.

The consequences of these findings are similar to those stemming from a finding of lack of trust in government. Where local residents do not perceive a clear benefit resulting from a potentially risky project, such as incineration of the harbor sediments, they would be foolish to support it. If a governmental agency wishes to convince a public that a project is necessary, it must communicate 
the advantages of that project to those who, presumably, stand to benefit the most from it.

\section{B. 5. Rnowledge of source of funding.}

Question 28 (Table 4.26) found a majority of the public random sample $(72 \%$ of Group 2$)$ to be unaware of the $\$ 110$ million contribution which the capacitor manufacturers made toward the cost of the harbor clean-up. This factor also helps explain the cynicism and lack of support which the public expressed toward the harbor clean-up. Arguably, a more widespread knowledge of the PRP settlement would impart to the public a sense of justice: the "polluter pays" principle. If, however, much of the public believes that she, as a taxpayer, is being forced to pay for the construction of a hazardous waste incinerator in her own neighborhood, the sense of victimization is complete. Again, the data are expressive of a failure in communication on the part of environmental decisionmakers, contributing to the conflict over remediation of the New Bedford Harbor Superfund site. 


\section{v. C. The New Bedford Harbor Superfund site and the reauthorization of CERCLA.}

The study has demonstrated, unexpectedly, that the facilitated discussions chaired by the Massachusetts office of Dispute Resolution regarding the New Bedford Harbor Superfund Site did not resolve conflict over the site,. where such resolution is defined as a convergence of risk perceptions. Rather, it seems that the effect of the discussions was to avert conflict by democratizing the decisionmaking process and fostering communication among the groups in opposition, without reconciling these groups' differences regarding the risks and benefits of the site and its cleanup. The extent to which the discussions succeeded in averting conflict appears to have been a function of their involvement of those groups with the most widely divergent views.

The study suggests that the public/governmental conflict over remediation of the New Bedford Harbor Superfund Site was caused, in part, by USEPA's failure to communicate to the public the risks of the site or the benefits of the proposed clean-up. The study's legal component has shown that easy solutions to such conflict are not to be found in the courtroom, but that the facilitated discussions in effect handed the group opposed to incineration a result which they would have had difficulty achieving in court. 
The proposals for CERCLA's reauthorization which were considered by Congress in 1994 called for greatly expanded public involvement in the superfund decisionmaking process. This study suggests that, to the extent that such a reform might involve citizens in Superfund decisionmaking before conflict arises, it holds promise for facilitating the peaceful implementation of Superfund clean-up plans in the future. The results of the study suggest a caveat, as well: that once conflict has arisen, improved public participation may not solve the problem, but simply prolong and politicize it. Such situations can only worsen Superfund's welldocumented lack of cost-effectiveness.

The treatment of hazardous waste, generally, has proven to be among the most difficult of problems in public environmental policy. The clean-up of superfund sites, therefore, will undoubtedly continue to generate fontroversy, particularly among those who reside in the area surrounding a proposed facility. Communication between government and citizens regarding such situations is fraught with difficulty. The issues are complex; risks and benefits are uncertain; lack of trust in government is a tremendous obstacle. The entire public participation process is a messy one.

And yet, as the New Bedford experience has shown, a small group of citizens is capable of short-circuiting a multi-million dollar remediation plan that ignores their interests. As glaringly imperfect as the process may be, 
public participation in superfund decisionmaking which is, in the words of the 1994 senate superfund reauthorization bill, "early, direct and meaningful" would seem to be, at this point, society's best bet for overcoming conflict in order to clean up contaminated sites successfully, expeditiously, and democratically. Local residents are the natural constituents of an environmental clean-up; in order to earn their support, environmental professionals should endeavor to keep them informed of the most important aspects of a project. By paying due attention to the opinions of local residents, as well, USEPA and other environmental agencies may work toward avoiding prolonged conflicts of the type which has attended the New Bedford Harbor Superfund Site. 
Appendix A: Initial perceptions of citizens and managers drawn from Jan 5, 1994 facilitated discussion.

The second of the series of facilitated discussions regarding the New Bedford Harbor Superfund Site was held on January 5, 1994, at the Greater New Bedford Vocational High school. At the request of the facilitator, Michael Keating, each of the discussion participants expressed his or her interests regarding the Site, in order for the group to understand the criteria of all sides in the environmental dispute. Individual participants were:

\section{Citizen Representatives:}

Concerned Parents of Fairhaven

Claudia Kirk

Kathleen Rocha

Downwind Coalition

Neal Balboni

Miana Cabbold

Carol Sanz

Hands Across the River

Eugene Grace

David Hammond

James Simmons 
Municipal Officials:

Eairhaven:

patrick Mullin

Jeff Osuch

Acushnet:

Roland Peppin

New Bedford -- Mayor's Office

Arthur Caron

New Bedford - - City Council

David Gerwatowski

Fred Kalisz

George Rogers

\section{Professional Resource Managers}

US Environmental Protection Agency

Frank Ciavatteri

Harley Laing

John MCNeil

Massachussetts Department of Environmental Protection

(MADEP)

Paul Craffey

Jay Naparstek

Helen Waldorf 
The following is an analytical summary, compiled 31 May 1994, of the major perceptual differences which emerged between the citizen representatives and the professional resource managers, gleaned from a videotape of the proceedings in the collection of the New Bedford Public Library. This identification of issues and differences was used to formulate the descriptive survey which serves as the principle data-gathering tool for this study.

It must be mentioned that, during this discussion, the elected officials stressed their alignment with the citizens' groups, thereby validating the choice of this research to combine elected officials with citizens for purposes of analysis.

I. Health risks associated with contamination v. risks of incineration

A. Citizens unconvinced of ambient risks of site; note uncertainty of science, age of data (1988).

Managers express great implicit faith in accuracy of risk assessment, relevance of state ambient criteria.

B. Citizens fearful of health risks resulting directly from incineration: stack emmissions (dioxin, furans, toxic metal particulate); solid waste (toxic ash).

Managers convinced that incineration will not cause significant new health risk.

C. Citizens fearful of hazards resulting indirectly from incineration: risk of fire or explosion.

Managers express faith in efficacy of risk management . 
II. Willingness to consider incineration

A. Citizens strongly oppose incineration; believe that emphasis of forum should be on finding alternatives.

Managers: Incineration remains a viable option; cost of switch in technologies must be justified.

III. Economics of incineration and remediation

A. Citizens believe hazardous waste incineration will cause economic harm to tourism and property values.

Managers believe that timely cleanup of Hot spot is key to economic revitalization of the harbor.

B. Citizens: Stigma of incineration will be permanent.

Managers: Incineration will produce short-term effect only.

IV. Cost of remediation alternative

A. Citizens: Public health is more important than cost; managers seem too concerned with costs.

Managers: Public health is paramount but agencies are obligated to contain cost, as well.

B. Citizens: The safest and best alternative must be found, in spite of existing decisions and contracts.

Managers: Existing decisions are difficult and expensive to change.

V. Time scale of remediation

A. Citizens stress need to take the time to make the proper choice of a remediation alternative.

Managers express need to expedite the cleanup, to reduce present risks. 
VI. Trust in government decisionmaking

A. Citizens: Agencies are not doing their job to adequately protect health of residents: lack of monitoring of PCB air emmissions from dredging; lack of EPA concern with metals.

Managers: Human health and the environment are our paramount concerns

B. Citizens: Agencies have not adequately facilitated public involvement: outreach, education, response.

Managers express desire to work with the public, to come to an agreement regarding cleanup of the site.

C. Citizens: Managers are creating negotiation context which favors the chosen alternative, re scheduling of dredging and availability of technical assistance.

Managers express willingness to keep an open mind, and consider alternatives.

VII. Scientific uncertainty

A. Citizens: Scientific uncertainty casts doubt on incineration.

Managers: uncertainty favors incineration.

B. Citizens express desire to consider innovative technologies.

Managers express importance of relying on proven technology. 


\section{Appendix B: Texts of coverletters and surveys.}

Contents:

B. 1. Coverletter for administration of survey to public random sample (Group 2), English.

B. 2. Public version of survey (Groups 1 and 2), English.

B. 3. Coverletter for administration and public version of survey (Group 2), Portuguese.

B. 4. Public version of survey (Groups 1 and 2), Portuguese.

B. 5. Sample of personalized coverletter used to administer survey to smaller groups (Groups 1, 3, and 4).

B. 6. Survey questions specific to professional groups (Groups 3 and 4). 


\section{B. 1. Coverletter for administration of survey to public random sample (Group 2), English.}

(Researcher name, affiliation and address)

New Bedford Harbor Superfund Site Survey

Dear Madam or Sir:

As you probably know, the sediments (mud) of the Acushnet River are contaminated with high levels of PCBs (polychlorinated biphenyls), particularly in the area north of the Coggeshall st. Bridge, between the towns of New Bedford and Acushnet. What to do about this contamination has been the source of great controversy over the past several years; the Federal Government, the State, and citizens' groups have all gotten involved in this debate.

This is an opinion survey, from which we hope to learn how you, personally, feel about this contaminated area of the river, which the government calls the New Bedford Harbor superfund site. We hope that this survey won't take more than 15 minutes of your time. Some of the questions may seem irrelevant, but please answer them anyway. There are no right or wrong answers; please read the questions carefully, then answer them in the way that best reflects your personal opinion.

The information which you provide will be kept COMPLETELY CONFIDENTIAL. Your name will not be given to any organization or company of any kind; you will not be put on any mailing lists. The surveys will be destroyed once the results are tabulated.

If you have any comments or questions about the survey, or about individual questions, you may contact Dr. Niels West, 401-792-2596, or the Vice Provost for Research, 70 Lower College Rd., University of Rhode Island, Kingston, RI 02881, 401-792-2635.

Sincerely,

(Signed)

(Researcher name and address) 


\section{B. 2. Public version of survey (Groups 1 and 2), English.}

$$
\text { - - SURVEY -- }
$$

Concerning the NEW BEDFORD HARBOR SUPERFUND SITE, Upper Acushnet River, New Bedford, Massachusetts.

The following survey should take about 15 minutes to complete. Please read the questions carefully, and answer them as completely and accurately as possible. THERE ARE NO RIGHT OR WRONG ANSWERS. Your responses will be kept COMPLETELY CONFIDENTIAL. Thank you for your time.

Name :

Date:

Address :

Town :

How long have you lived in the. New Bedford area? years. Employer:

Position:

What does this company do?

1. Did you know that there is a SUPERFUND SITE, that is, a FEDERALLY RECOGNIZED HAZARDOUS WASTE SITE in the Acushnet river?

$$
\text { Yes ㄴ No }
$$

2. If so, approximately how Iong have you known about this site? (Please check one)

Less than 6 months...

6 months to 1 year...

$1-2$ years.............

$2-5$ years............

More than 5 years...

3. Have you ever been active in any group or organization which was concerned with this Superfund site?

Yes

No

4. If "Yes," please name the group

When, approximately, were you active in it?

(Month/Year) :

to / 
5. Do you smoke cigarettes?

Yes

Sometimes

No

6. Do you wear a seatbelt when you drive?

Yes

Sometimes

No

7. What SOURCES OF INFORMATION are important to you, concerning LOCAL events and controversies?

(Please CHECK all that apply.)

Radio

Television

Newspaper (please name)

Conversation with friends or neighbors, or at work

Children hear about things at school

Town meetings or public meetings

other (Please write in).

The rest of this survey asks about the New Bedford Harbor Superfund site and its clean-up. Some of the questions make use of a line, called a Likert scale, which symbolizes a range of values between two opposite ideas. PLEASE READ EACH QUESTION CAREFULLY, THEN PLACE AN "X" anywhere along the line, at the point which best reflects your judgement.

\section{EXAMPLE}

X. In your opinion, what is a good day to go to the beach?

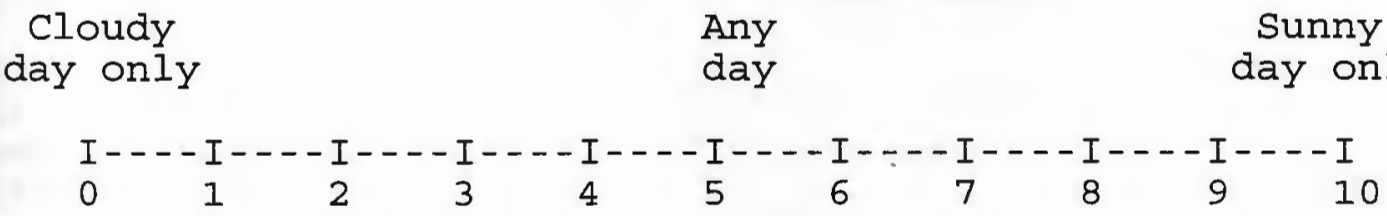

According to the United States Environmental Protection Agency (EPA) and the Massachusetts Department of Environmental Protection (DEP), the Acushnet River is CONTAMINATED WITH PCBS AND TOXIC METALS, particularly in the area north of the Coggeshall st. bridge. The next six questions relate to this CURRENT pollution problem. Please DO NOT consider EPA's recent dredging activities in making your assessment. In other words, "CURRENT" FOR THESE PURPOSES MEANS IN THE LAST YEAR OR SO. 
8. To what extent do you feel that the contamination of the Acushnet River is a HEALTH RISK?

No current

health risk
Moderate health risk
Great current health risk

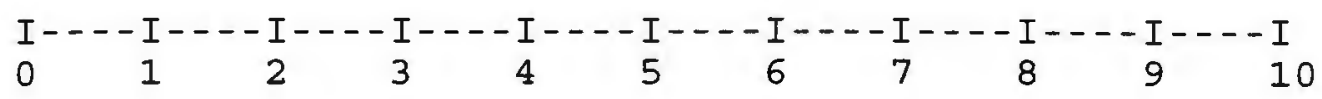

9. Who would you say is AT RISK from this contamination? (Please CHECK ALL that apply).

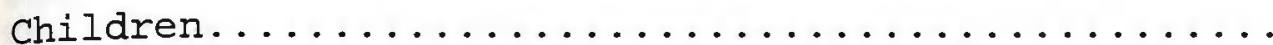

old people.

Sick people.

People who eat fish.

People who use boats.

Portuguese people..

Non-Portuguese people.

Residents of the neighborhood where the pollution is

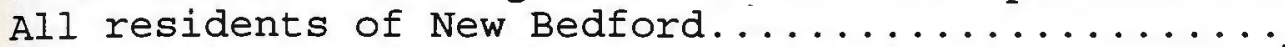

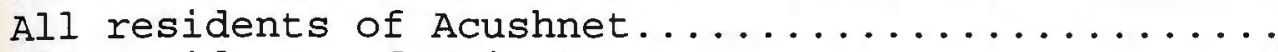

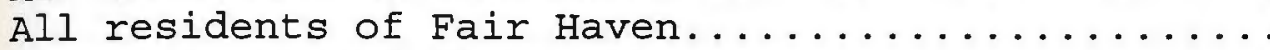

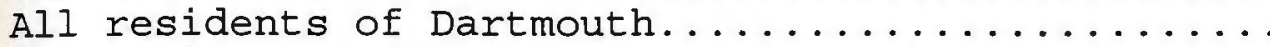

All residents of Southeastern Massachusetts.......

Other (Please write in)

10. WHAT do you see as the health risks of the current contamination? (Please CHECK ALL that apply.)

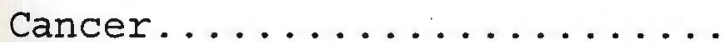

Skin problems.

Respiratory problems........

Liver problems............

Heart trouble.............

Leukemia................

Sexual problems...........

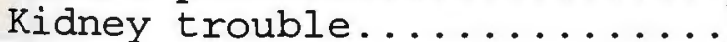

Brain problems.............

Other (please write in):

11. In your opinion, HOW might these risks be transferred from the river to humans? (Please CHECK ALL that apply).

Breathing air......

Digging soil............

Eating fish.
Drinking water..........

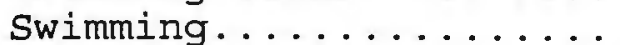

Eating garden vegetables.

Other (please name) 
12. Are you a commercial fisherman, or are any of your family or close friends commercial fishermen?

Yes

No

Relationship:

Yourself___ Immediate family

Extended family

Friend

What kind of fishing?

13. The Government (EPA) has completed studies which show that the CONTAMINATION of the Acushnet is a real health risk to local people. In your opinion, how certain is this assessment? In other words, HOW MUCH do you think that the Government's scientists REALLY KNOW about the HEALTH RISKS of this contamination?

They know

very little
They know

something
They know

a great deal

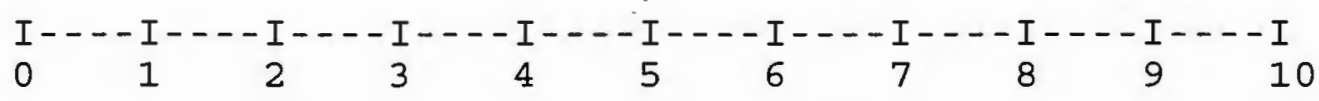

14. How did you, personally, learn about this contamination problem and its risks? (Please write in.)

In 1990, the EPA decided that the best way to SOLVE THE PROBLEM OF PCB POLLUTION in the Acushnet River would be to dredge the most contaminated sediments from the river and to incinerate (burn) the sediments in a special incinerator. This incinerator would have been temporarily assembled in the North End of New Bedford.

Now, the dredging is under way but the incinerator decision has been suspended while A NEW CLEAN-UP TECHNOLOGY IS CHOSEN. The next nine questions concern the CLEAN-UP of the polluted Acushnet River sediments. 
15. Do you think that it is SAFER TO HUMANS, AND BETTER FOR THE ENVIRONMENT, for the EPA to REMOVE (dredge) the most contaminated sediments from the Acushnet River, or to LEAVE them in place?

Do not dredge Not sediments

sure
Dredge sediments

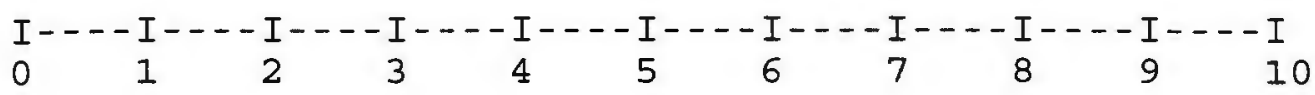

16. As a way of REDUCING THE RISKS associated with the PCB and metals contamination of the Acushnet River, INCINERATION would be:

$\begin{array}{lrl}\text { Completely } & \text { Not } & \text { Completely } \\ \text { unacceptable } & \text { sure } & \text { acceptable }\end{array}$

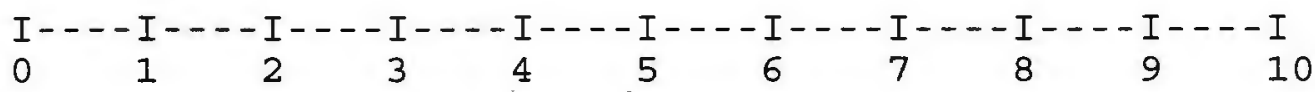

17. How would you rate the HEALTH RISK OF INCINERATING PCBS AND TOXIC METALS in the North End of New Bedford?

No

risk
Moderate risk
Extremely

risky

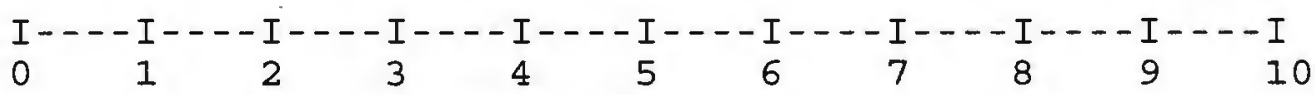

18. In terms of HEALTH RISKS, what specific aspects of INCINERATION would most concern you? (Please RANK I - 5, where 1 is the most important, 5 is least important.)

Air pollution (respiratory disease)

Chance of fire

Toxic ash

Chance of explosion

Chance of spills or accidental releases

other (Please name) 
19. In terms of HEALTH RISKS FROM AIR EMMISSIONS (SMOKESTACK) FROM THE INCINERATION, what possible RELEASES would most concern you?

(Again, please RANK, $1-6$, where 1 is most important, 6 is least important.)

\section{Dioxin}

Heavy Metals (such as lead)
PCBs
Greenhouse gasses
Radiation
Other toxic chemicals
Other (Please name)

20. The Government's (EPA's) scientists have stated that the INCINERATION would present LITTLE OR NO HEALTH RISK to surrounding residents. In your judgement, how much do the scientists REALLY KNOW ABOUT THE HEALTH RISKS of this incineration?

They know

very little
They know something
They know

a great deal

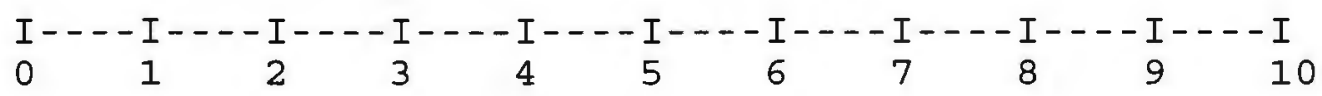

21. If the Government (EPA) does know about the risks of incineration, to what extent do you think they TELL THE PUBLIC THE TRUTH about such risks?

They tell very little of the truth
They tell some of the truth
They tell the truth $100 \%$

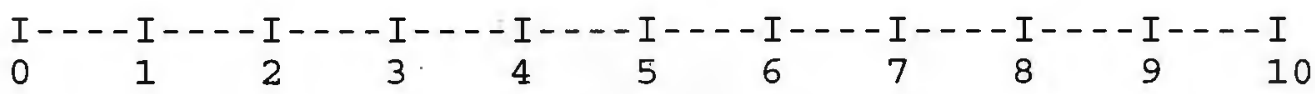

22. HOW CLEAN, AND HOW SAFE, do you expect the Acushnet River to be when the Government (EPA) is DONE CLEANING IT UP?

As dirty \& unsafe as before

Safe for swimming
Fish will be edible
Shellfish will be edible

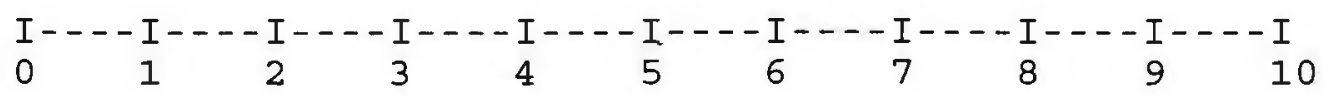


23. In general, how GOOD $A$ JOB is the Government (EPA) doing to PROTECT THE HEALTH of the public as regards the New Bedford Harbor Superfund Site?
A poor job
An O.K. job
An excel-
lent job

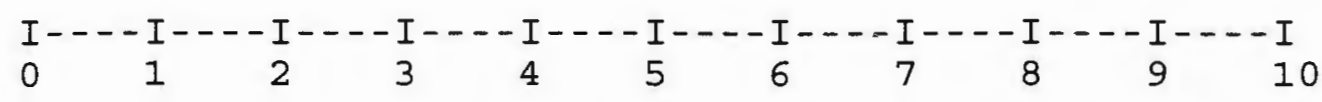

24. What, in your opinion, would be the overall ECONOMIC EFFECT of the proposed INCINERATOR on the Greater New Bedford Area?

Harmful

economic effect

No economic effect
Beneficial economic effect

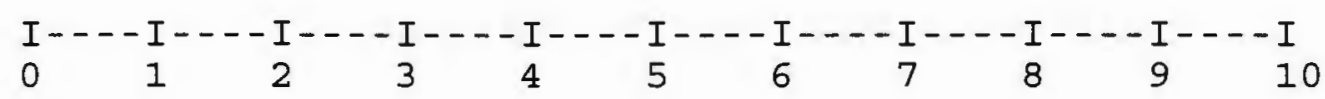

25. What, in your opinion, would be the overall ECONOMIC EFFECT on the Greater New Bedford Area of HAVING A CLEANER HARBOR?

Positive

economic effect

No economic effect
Negative economic effect

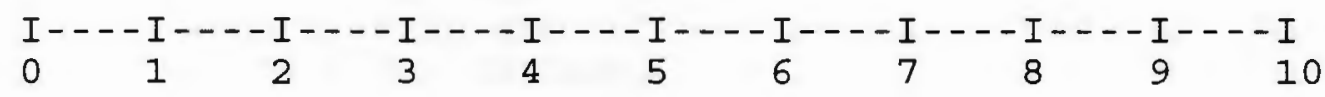

26. WHAT WOULD YOU LIKE TO SEE regarding the harbor cleanup? (Please CHECK ALL that apply).

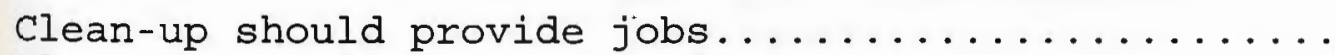

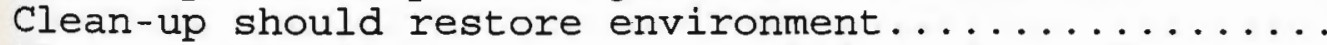

Clean-up should restore commercial options of harbor.

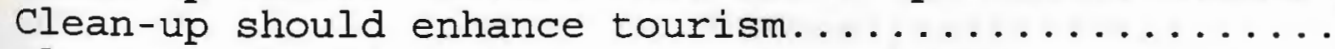

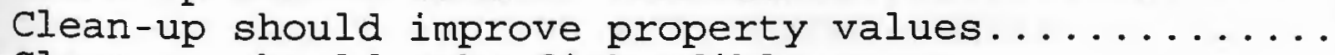

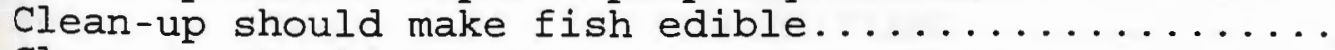

Clean-up should not cost taxpayers money..........

Other (Please write in) 
There will always be some degree of trade-off between the need to guarantee public health and safety, and the need to find a cost-effective way of cleaning up the contamination in New Bedford Harbor. The following questions concern the COST OF CLEANING UP THE HARBOR, whether by incineration or any other means. Regardless of the method finally chosen, the cleanup of the harbor will cost many millions of dollars.

27. What do you consider to be the BEST BALANCE between assurance of PUBLIC HEALTH, and COST of cleanup.

$\begin{array}{llr}\text { Clean-up } & \text { Health } & \text { Public health } \\ \text { must be as } & \text { and cost } & \text { is most important, } \\ \text { inexpensive } & \text { are equally } & \text { regardless of } \\ \text { as possible } & \text { important } & \text { cost }\end{array}$

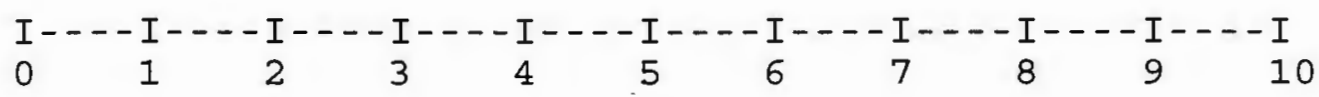

28. Who will pay for this cleanup?

29. How much would you, personally, be WILLING TO PAY IF YOU COULD BE SURE that the Acushnet river would be cleaned to the point where FISH AND SHELLFISH WERE SAFE TO EAT, and the river was SAFE FOR CHILDREN TO SWIM in?

One-time payment, in dollars:

$$
\begin{aligned}
& \text { I----I----I----I----I----I----I--.-I----I----I----I }
\end{aligned}
$$

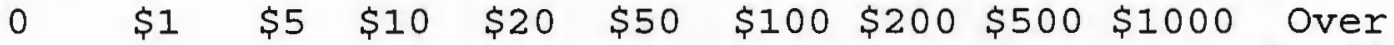

30. How much would you, personally, be WILLING TO PAY IF YOU COULD BE SURE that the Acushnet river would be cleaned to the point where it was NO LONGER HIGHLY CONTAMINATED, but still NOT SAFE ENOUGH TO SWIM OR FISH?

One-time payment, in dollars:

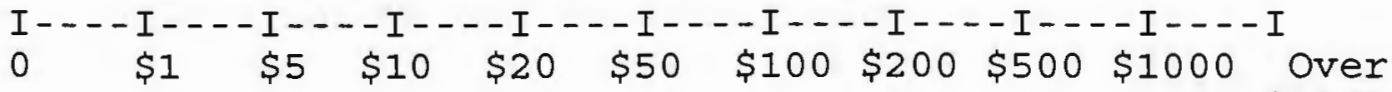

$$
\begin{aligned}
& \$ 1000
\end{aligned}
$$


31. In your opinion, has the Government (EPA) done a GOOD JOB OF INFORMING THE PUBLIC about the CURRENT RISKS of the New Bedford Harbor Superfund Site on the Acushnet River?

$\begin{array}{rlr}\text { Poor } & \text { O.k. } & \text { Excellent } \\ \text { job } & \text { job } & \text { job }\end{array}$

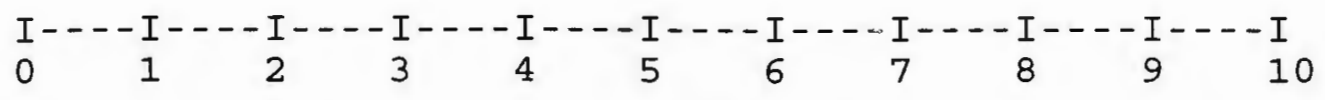

32. In your opinion, has the Government (EPA) done a good job of INFORMING THE PUBLIC about its PROPOSED CLEANUP of the Acushnet River sediments?

$\begin{array}{clc}\text { Poor } & \text { O.k. } & \text { Excellent } \\ \text { job } & \text { job } & \text { job }\end{array}$

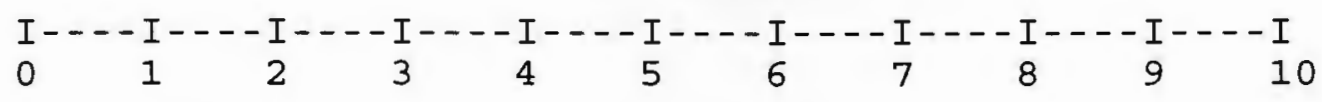

33. In your opinion, has the Government (EPA) done a good job of LISTENING TO THE PUBLIC about the superfund site and its cleanup?

$$
\begin{aligned}
& \text { Poor } \\
& \text { job } \\
& \text { O.K. } \\
& \text { job } \\
& \text { Excellent } \\
& \text { job }
\end{aligned}
$$

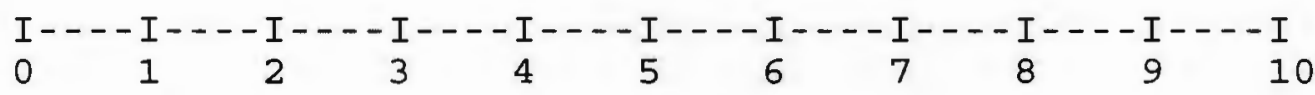

34. In your opinion, to what extent would the Government (EPA) LET PUBLIC OPINION INFLUENCE ITS DECISIONS regarding the Superfund Site and its cleanup? In other words, HOW MUCH OF A SAY does the local public really have in the Government's decisions?

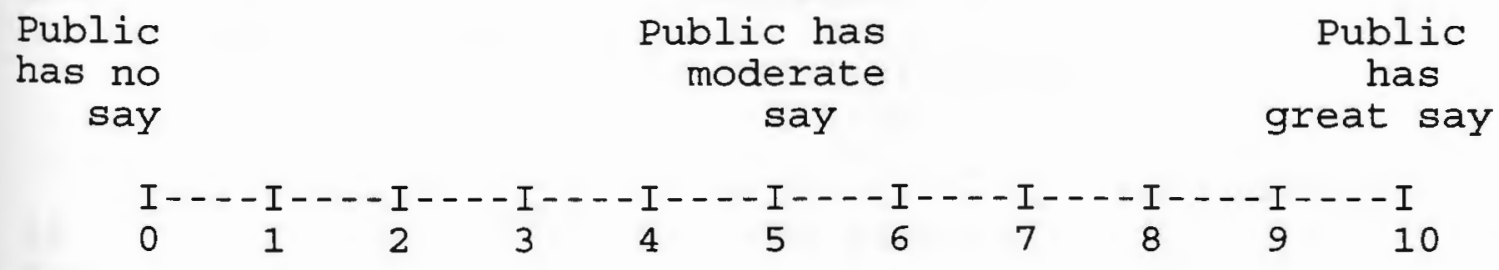


35. What could the Government have done to IMPROVE THE PROCESS OF PUBLIC INVOLVEMENT at the New Bedford Harbor Superfund Site? (Please RANK $1-7$, where 1 is the most important, 7 is the least important.)

More public meetings

Radio \& television spots

More programs in schools

More newspaper coverage

Door to door information campaign

Mailings

Other (Please write in)

Dealing with scientific uncertainty is part of any Superfund clean-up. The next five questions relate to this uncertainty, in the context of superfund decisionmaking in New Bedford Harbor.

36. Given that SCIENTIFIC UNCERTAINTY must be a reality of decisions regarding the New Bedford Harbor Superfund site, do you think that the uncertainty -- the doubt -- about the risks FAVORS THE CLEANUP, Or FAVORS LEAVING THE SITE AS-IS?

Leave site Not Clean up

$$
\text { as-is. sure the site. }
$$

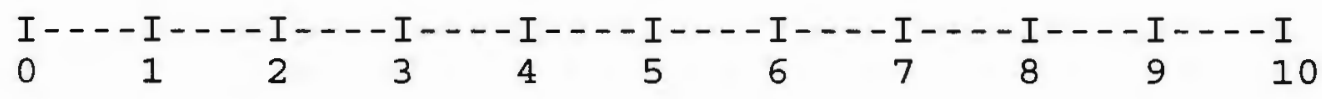

\begin{tabular}{|c|c|c|}
\hline $\begin{array}{l}\text { Time scale } \\
\text { is } \\
\text { unimportant }\end{array}$ & $\begin{array}{l}\text { Moderate } \\
\text { delays } \\
\text { acceptable }\end{array}$ & $\begin{array}{l}\text { Site must } \\
\text { be cleaned u } \\
\text { immediately }\end{array}$ \\
\hline$---I$ & $\begin{array}{c}--I \cdots-\cdots \\
5\end{array}$ & $\begin{array}{cc}-I-- & -I--- \\
8 & 9\end{array}$ \\
\hline
\end{tabular}

37. In your opinion, how important is it to HURRY THE CLEANUP of the harbor along?

38. Please explain briefly the factors influencing your judgement on Question 36: 
39. Again, given that there is scientific uncertainty regarding both the risks of the contamination and the risk of the cleanup, how should we deal with SCIENTIFIC

UNCERTAINTY in CHOOSING A CLEANUP METHOD for New Bedford Harbor?

Need a proven, time-tested technology

\author{
The two are \\ equally \\ important
}

Need an innovative technology

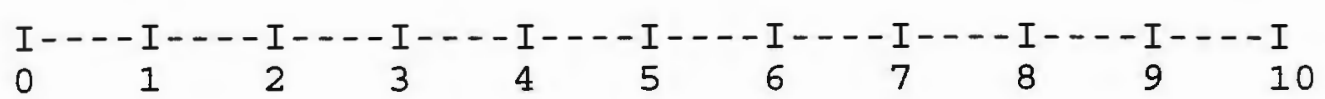

40. In conclusion, do you feel that it would be a GREATER HEALTH RISK to LEAVE the contaminated Acushnet sediments where they currently sit, or to TREAT THEM BY INCINERATION?

Existing contamination is greatest risk
Incineration

Equal risks is greatest risk

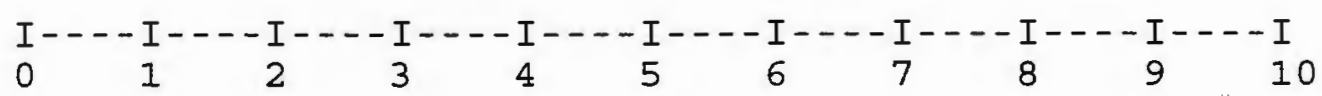



random sample (Group 2), Portuguese.

\author{
$P O R$ T U G U E S
}

\title{
Questionario de o Porto de New Bedford
}

Estimado Senhora ou Senhor:

Como voce provavelmente sabe, os sedimentos (lodos) do rio Acushnet estao contaminados com altos niveles de PBC (PCBs ou bifenilos polyclorinados), especialmente na area norte da ponte do Caminho Coggeshall (Coggeshall st. Bridge). Esta contaminacao tem sido uma funte de contravencao, duranto os ultimos anos. O Governo Federal, e o estado de Massachusetts, e varios grupos locales tem tentado resolver este problema.

Este questionario e para voce poder dar a sua opiniao, da area que o Governo Federal chama o "New Bedford Harbor Superfund Site." Nos esperamos que este questinario no leve mais de que 15 minutos para complitar. Estas preguntas sao para voce dar a sua opiniao, emtam nao a uma resposta que e mais certa de que outra. Por favor complete todas as preguntos.

Como voce vive na area que esta contaminado nos queremos saber sua opiniao. A suas respostas as preguntas que nos preguntamos vao ser CONFIDENCIAL. Depois de obter a informacao, nos vamos destruir os questionarios.

Se voce tem alguma pregunta por favor entre en contacto com nos. Pode conversar com Dr. Niels West, 401-792-2596 o com - Vice Preboste de Investigacao, 70 Lower College Rd., University of Rhode Island, Kingston, RI 02881, 401-7922635. Eu agradeco sua ajuda.

Obrigado,

(Signed)

(Researcher name and affiliation) 


\section{B. 4. Public version of survey (Groups 1 and 2), Portuguese.}

\section{QUESTIONARIO \\ Acerca do \\ PORTO DO NEW BEDFORD}

Este questionario deve levar 15 minutos para completar. Por favor leia cada pregunta cuidadosamente, e responda completamente. NAO A RESPOSTAS CORRECTAS OU ERRADAS. Suas respostas sera confidencial.

Nome :

Endereco:

Data:

A quanto tempo vive cerca New Bedford? Cidade:

Empregador:

Posiciao:

Que faz essa companhia?

1. Sabes que existe um SUPERFUND SITIO (CONTAMINACAO PERIGOSA) no rio de Acushnet? Sim Nao

2. Se sua resposta e positiva, A QUANTO TEMPO JA SABE deste sitio? (Escolha um)

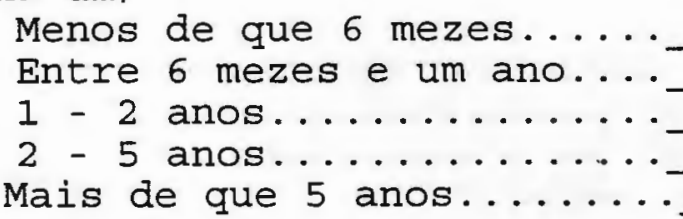

3. La participaste num grupo que occupa-se de este asunto do "Superfund Site?" Sim NaO

4. Se a resposta e positiva qual e o nome do groupo:

Quando partisipaste neste groupo? (Mez/Ano) '

5. Fuma cigarettes? Sim As vezes Nao 6. Fez uso do cinto de seguranca cuando guia um automovel? $\operatorname{Sim}$ As vezes Nao 
7. Como e que recebe sua INFORMACAO sobre eventos LOCALES? (Marca todos que aplicam)

Radio

- Television

Journal (qual)

Conversa com amigos o vecinos, o no trabalho

Filhos aprendem na escola

Reuniaos publicas

Otras formas (escrevaque tipo)

Qual e MAIS IMPORTANTE?

Segunde mais importante

As seguintes preguntas sao dirigidas a o projecto "Superfund Site" no porto de New Bedford. Umas das preguntas faz uso do "Likert Scale" para symbolizar o disposto de valor entre duas situacaos. Marca com um "X."

$$
\text { E X E }
$$

X. Em sua opiniao, qual e o melhor dia para ir a praia?

Dia nubrado Qualquer dia

Dia de sol

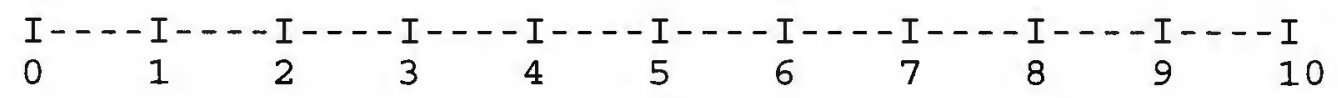

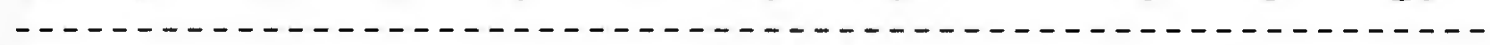

De acordo com a Agencia de Proteccao do Ambiente, e o Departamento do Ambiente de Massachusetts, o rio de Acushnet esta contaminado com altos nivels de PBC (PCBs) e metales toxicos. Nao considera as actividades de limpeza duranto o ultimo ano.

8. A qual grau de valor voce pensa que a comtaminaciao do rio Acushnet representa PERIGO A SAUDE?

Nao e perigo

Perigo

Grande

corrente mediano perigo

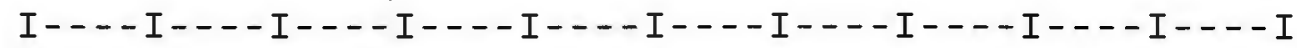

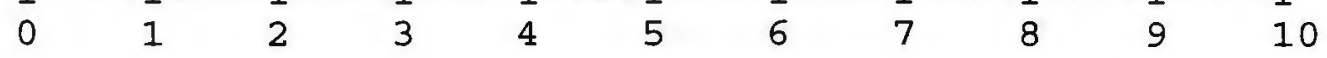


9. Em. sua opiniao quem e que esta em prigodo desta comtaminacao?

(Marca todos que aplicam)

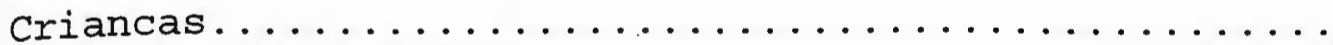

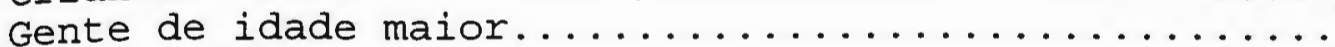

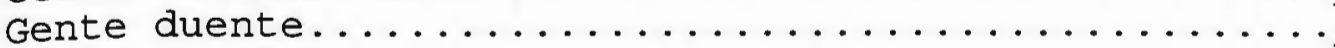

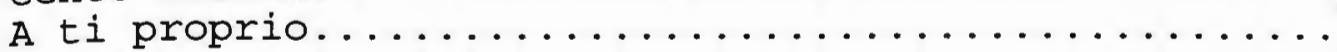

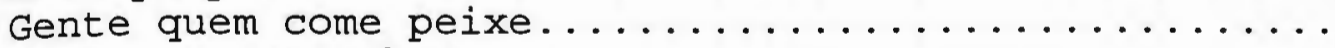

Gente que usam barcos.

os Portugueses..................

Quem nao e Portugues.

A gente que vive na area que esta comtaminada.......

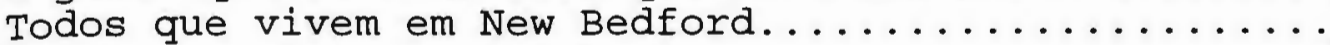

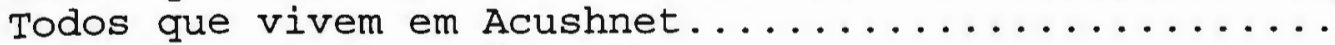

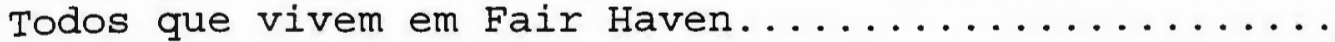

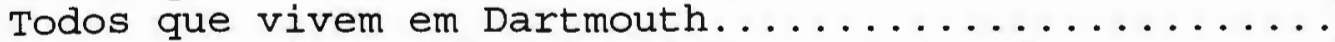

Todos que vivem sul este de Massachusetts...........

Otra gente (por favor escreva)

10. Em sua opiniao, qual sao os perigos da comtaminacao? (Marca todos que aplicam)

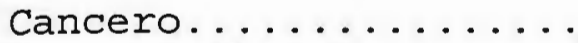

Doencas da pel.........

Problemas respiratorios

Problemas do figado....

Problemas do coracao...
Leukemia.............

Problemas sexuales. .

Problemas das rimes.

Problemas do cerebro

Otros problemas (por favor escreva)

11. Na sua opiniao, COME e que estes perigos podem ser transferidos do rio a humanos? (Marca todos que aplicam)

Respirando o ar....

Cavando a terra...

Comendo piexe.....

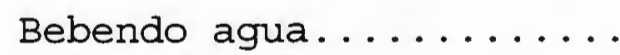

Passar a nadar...........

Comendo vegetales do jardim

Otras formas (por favor escreva)

12. Es um piscador comercial, ou alguem da tua familia? Sim Nao

Relacao: Tu mesmo

Familia

Familia proxima

Amigos

Que tipo de pesca? 
13. O Govervo (EPA) fez imvastigacaos que indicarao que a COMTAMINACAO do rio Acushnet representa um perigo a o povo local. Em sua opiniao, QUANTO SABE o governo dos perigos que existe no rio?

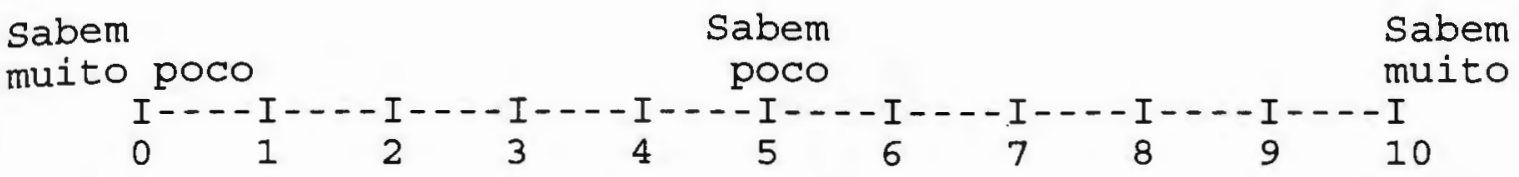

14. Como e que voce informo-se dos PERIGos e da comtaminacao?

Em 1990, O Governo (EPA) decidio que a melhor forma para RESOLVER O PROBLEMA DA COMTAMINACAO do rio era para tirar, e queimar os sedimentos. O forno de incineracao era para ser construido temperiamente em o Norte de New Bedford.

Agora a limpeza continua, mais o forno de incineracao AINDA NAO FOI CONSTRUIDO. As preguntas que siguem sao dirigidas limpeza do Rio.

15. En sua opiniao, acha que a limpeza do Rio TEM BENEFICIOS PARA TODOS, E PARA O AMBIENTE, ou deve O Governo (EPA) deixar todo como esta?

Tirar

os sedimentos

Nao faz

Diexe

do Rio

diferenca

os sedimentos

ficar

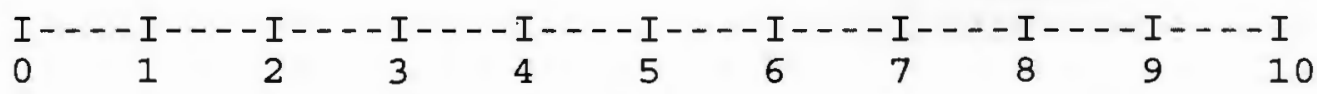

16. Da perspectiva da sua saude, acha que incinerar os $\mathrm{PBC}$ (PBCs) e metales e:

Totalmente

inaceitavel

$$
\begin{aligned}
& \text { Nao estou } \\
& \text { seguro }
\end{aligned}
$$

Totalmente aceitavel

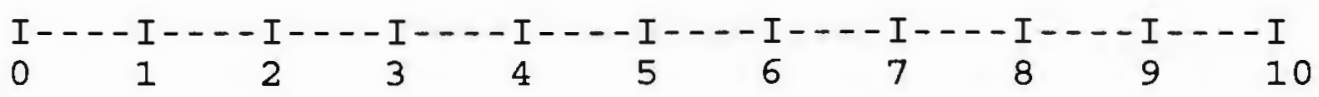


17. Referir-se A SAUDE, como medes OS PERIGOS DE QUEIMAR OS comtaminante em $\circ$ Norte de New Bedford?

Nao a

Pouco

Muito perigo

perigoso

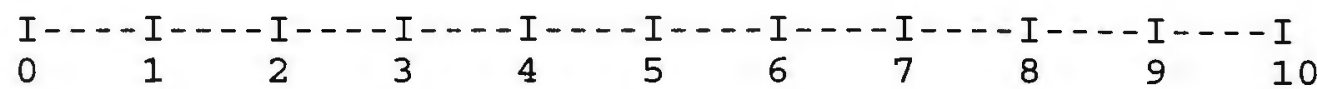

18. Referir-se A SAUDE, qual e a RAZAO que voce nao aceita o forno de INCINERACAO? (Marce de 1 -- mais importante, a 5 -menos importante)

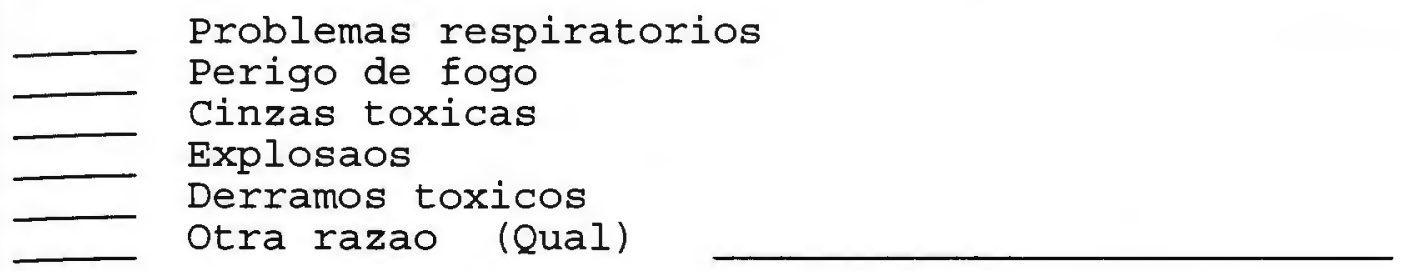

19. REFERIR-SE A SAUDE, qual das DESCARGOS DA CHAMINE te preocupa?

(Marce de 1 -- mais importante, a 6 -- menos importante)

\section{Dioxin}

- Metales pesados (tales como plomo)

$\mathrm{PBC}$ (PBCs)

Gases do efeito invernado (greenhouse gasses)

Radiaciao

Otros quimicos toxicos

Otras (Qual)

20. O Governo indica que o forno de incineracao e seguro. QUANTO achas que o Governo (EPA) REALMENTE SABE SOBRE O PERIGO do forno de incineracao?

Sabe muito

Sabe

Sabe

pouco

pouco muito

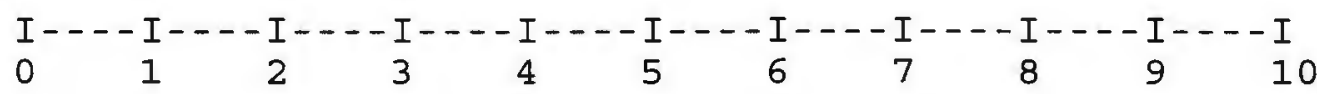

21. Se o Governo (EPA) sabe dos perigos, QUANTO ACHAS QUE DIZ ou povo?

Nao dizem

Dizem nada pouco

Dizem $100 \%$

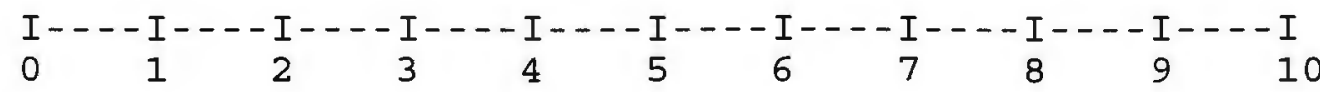


22. Achas que o Rio vai ficar?

$\begin{array}{llll}\text { Como estava } & \text { De forma } & \text { De forma } & \text { De forma } \\ \text { antes } & \text { de poder } & \text { de poder } & \text { de poder } \\ \text { (perigoso) } & \text { nadar } & \text { piscar para } & \text { comer os } \\ & & \text { comer } & \text { mariscos }\end{array}$

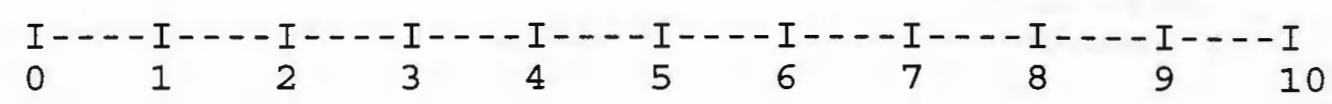

23. Achas que o Governo (EPA) esta protegimdo a saude do povo da contaminacao?

NaO

Mais o menos

Excelente

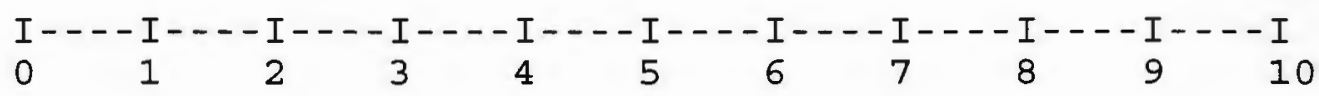

24. Em sua opiniao, qual sera o EFEITO ECONOMICO de ter o forno de incineracao na area de New Bedford?

Efeito economico negativo

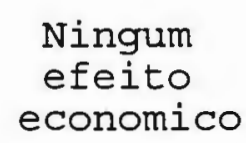

Ningum

efeito economico

Efeitos economico positivo

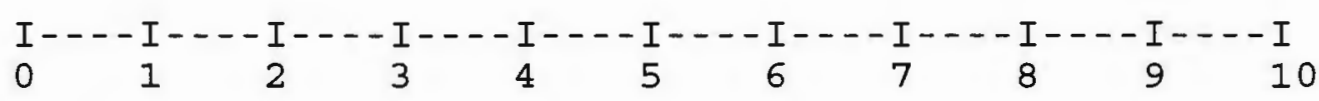

25. Em sua opiniao, qual sera o EFEITO ECONOMICO na area de New Bedford de ter o RIO LIMPO?

Efeito economico negativo

$$
\begin{aligned}
& \text { Ningum } \\
& \text { efeito } \\
& \text { economico }
\end{aligned}
$$

Efeitos economico positivo

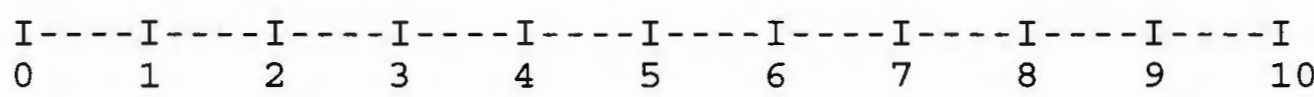


26. Que gustarias de ver associado com a limpeza do Rio? (Marca todos que aplicam)

A limpeza devia de produzir trabalos...............

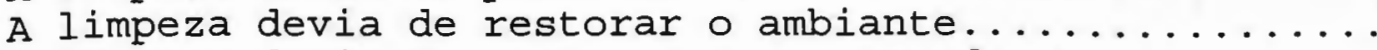

A limpeza devia de restorar o comerco da area.........

A limpeza devia de proteguir a saude do povo da area...

A limpeza devia de melhorar o valor da propriedade.....

A limpeza devia de pirmitir o comsume do peixe.........

A limpeza devia de nao levantar os impostas...........

Otras (Por favor escreva)

Sempre existe um grau de compromisso entre a necesidade de uma garantia para a saude, e a seguridade publica, asim como a necesidade de encontrar uma maneira efeitiva de limpar a comtaminacao do Porto de New Bedford. As siguintes preguntas sao dirigidas ou PRECO DE LIMPAR O RIO. De todas as formas a limpeza vai custar milhoes de dolaras.

27. Que opinas e o MELHOR BALANCO entre a GARANTIA DA SAUDE e O PRECO DA LIMPEZA?

A limpeza deve ser o mais barato possivel
A saude e o preco sao egual de importancia
A saude publica e o mais importante

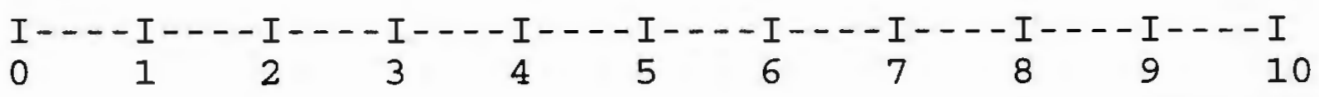

28. Quem deve pagar para esta limpeza?

29. QUANTO PAGARAS PAR TER A CERTEZA que O Rio vai ser bem limpo, e que se pode COMER MARISCOS E PEIXE, e tambem as CRIANCAS PODEM NADAR NO RIO?

So uma vez (dolaras) :

$$
\begin{aligned}
& \text { I----I----I----I----I----I----I----I----I----I----I } \\
& \begin{array}{lllllllllll}
0 & \$ 1 & \$ 5 & \$ 10 & \$ 20 & \$ 50 & \$ 100 & \$ 200 & \$ 500 & \$ 1000 & \text { Sobre }
\end{array} \\
& \$ 1000
\end{aligned}
$$


30. QUANTO PAGARAS PARA TER A CERTEZA que o Rio vai ser bem limpo, e que nao teija comtaminado e nao e seguro para nadar ou pescar?

So uma vez (dolaras):

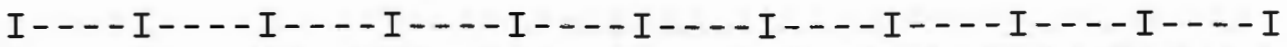

$$
\begin{aligned}
& 0 \quad \$ 1 \quad \$ 5 \quad \$ 10 \quad \$ 20 \quad \$ 50 \quad \$ 100 \quad \$ 200 \quad \$ 500 \quad \$ 1000 \text { Sobre } \\
& \$ 1000
\end{aligned}
$$

31. Em sua opiniao, o PERIGO DA COMTAMINACAO foi BEM POBLICADO por o Governo (EPA)?

$$
\text { Nao Mais o menos Excelente }
$$

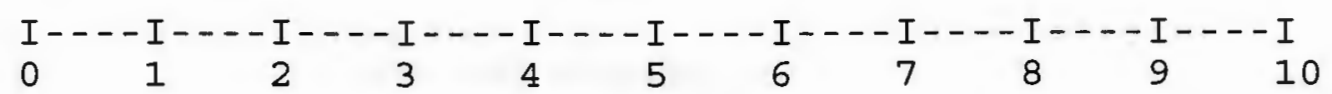

32. Em sua opiniao, o Governo. (EPA) INFORMOU BEM O POVO da LIMPEZA do Rio?

$$
\begin{aligned}
& \text { Nao Mais o menos Excelente }
\end{aligned}
$$

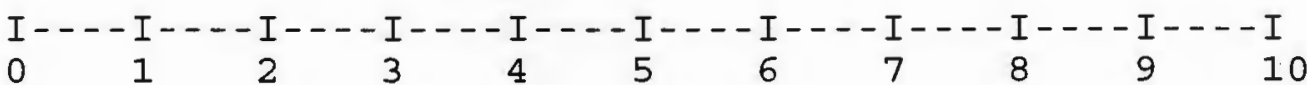

33. Em sua opiniao, o Governo (EPA) PRESTO ATENCAO A OPINIAO PUBLICA acerca da comtaminacao e a limpeza?

$$
\begin{aligned}
& \text { Nao Mais o menos Excelente }
\end{aligned}
$$

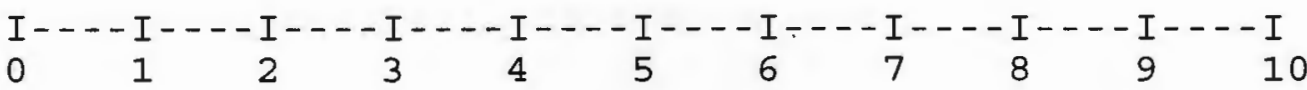

34. Em sua opiniao, ACHAS QUE O POVO LOCAL TEVE ALGUM PODER em que o Governo (EPA) vai fazer com a limpeza do Rio?

Pouco Mais o menos Muito

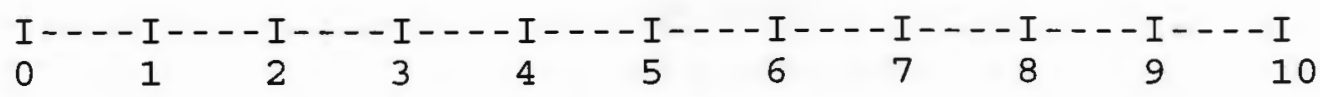


35. Que podia ter feito o Governo (EPA) para INCLUIR O POVO NO PROGREDIMENTO da limpeza do Rio? (Marca de 1 - 7. 1 mais importante; 7 menos importante)

Mais renioes publicas

Anuncios no radio e TV

Mais programas nas escolas

Mais anuncios no jornal

Informacao de porta a porta

Correio

Otras formas (Por favor escreva)

As preguntas que siguem sao dirigidas a duvida do Governo (EPA) na limpeza do Rio.

36. Sem os resoltados ser domostrados na limpeza do Porto de New Bedford, achas que o Governo deve limpar o Rio ou deixarlo como esta?

Deixa

com esta
Nao esta seguro
Em favor

da limpeza

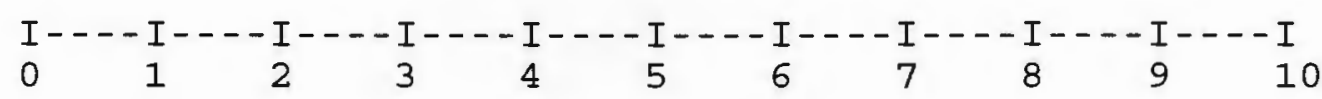

37. Em sua opiniao, o Rio deve ser limpo apressadamente?

o tempo

nao e

importante
Demore moderade se pode aceitar
Deve ser

limpo imediatamente

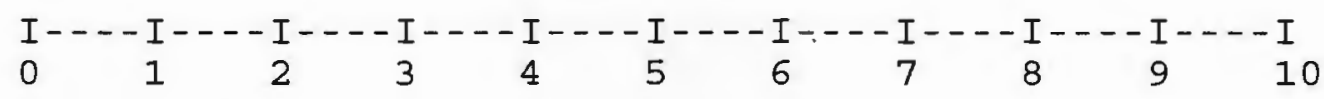

38. Qual sao os fatores que influio a sua resposta na pregunta 36 . 
39. Otra vez, referindonos a os trabalhos cientificos que NAO DAO CERTEZA DO PERIGO QUE EXISTE em limpar O Rio, como devemos escolher o sistema de limpar o Porto de New Bedford?

Com uma

tecnologia

As duas

Necesitamos

sao

provada

importante uma nova tecnologia

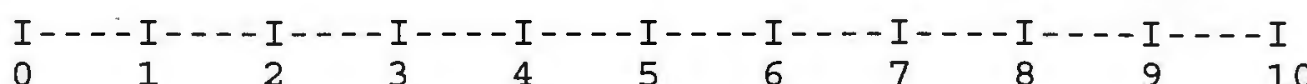

40. Em conclusao, achas que DEIXAR os comtaminentos no Rio E MAIS PERIGOSO, OU QUEIMARLOS NO FORNO DE INCINERACAO DA MAIS PERIGO?

A comtaminacao

e o perigo

Equal

Incineracao maior

e o perigo maior

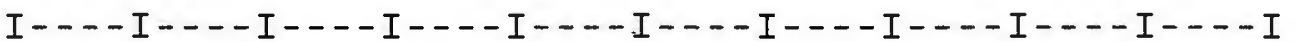

$$
\begin{aligned}
& \begin{array}{lllllllllll}
0 & 1 & 2 & 3 & 4 & 5 & 6 & 7 & 8 & 9 & 10
\end{array}
\end{aligned}
$$




\section{B. 5. Sample of personalized coverletter used to administer survey to smaller groups (Groups 1, 3 , and 4).}

(Subject name and address)

5 October 1994

Dear Marguerite:

Enclosed are copies of the survey which we discussed by telephone this week, along with a couple of return envelopes. I realize how busy you are; thanks for agreeing to take the time to participate in this study.

If some of the questions seem rather basic, please bear with me; parts of this survey are being administered to a broad cross-section of people, not all of whom are likely to be as familiar with this type of site as you are. I don't think the survey will take any more than 15 minutes of your time. There are, of course, no right or wrong answers; please read the questions carefully, then answer them in the way that best reflects your personal opinion. I am not interested in official statements or agency positions, but rather, would like to know how you, personally, perceive this situation.

The information which you provide will be kept completely confidential. The surveys will be destroyed once the results are tabulated. Again, I realize the demands of your schedule, but would be most appreciative if you were able to return the survey within a week or two.

If you have any comments, questions, or complaints about the survey, you may contact myself; my advisor, Dr. Niels West, 401-792-2596; or the Vice Provost for Research, 70 Lower College Rd., University of Rhode Island, Kingston, RI 02881, 401-792-2635. Thank you; I look forward to your response.

Sincerely,

(Researcher name, affiliation, and address) 
B. 6 .

Concerning the NEW BEDFORD HARBOR SUPERFUND SITE, Upper Acushnet River, New Bedford, Massachusetts.

The following survey should take about 15 minutes to complete. Please read each question carefully, then answer them as completely and accurately as possible. There are no right or wrong answers; please note that I am looking for your personal opinion, not an official agency or departmental position. Your responses will be kept completely confidential. Thank you for your time.

Name : Date :

Town of residence:

Have you lived in the New Bedford area?

If so, for how long? years

Employer :

Position or Title:

1. How long have you been involved, generally, in environmental management? years

2. In working on a particular site, how often, on average, do you converse with non-professionals -- stakeholders -interested in a site? (Please CHECK ONE.)

At least once a day........

Several times per week......

Once a week..............

Several times per month....

Once a month..............

Less than once a month......

Varies too much to say...... 
3. Please characterize your role in site management by RANKING the following, where 1 is the most important, 5 is least.

Managerial

Technical

Legal

Public information

Other (Please write in)

4. Do you smoke cigarettes?

Yes _ Sometimes___ No

5. Do you wear a seatbelt when you drive?

Yes

Sometimes

No

The rest of this survey asks about the New Bedford Harbor Superfund Site and its clean-up. Some of the questions make use of a line, called a Likert scale, which symbolizes a range of values between two opposite ideas. PLEASE READ EACH QUESTION CAREFULLY, THEN PIACE AN "X" anywhere along the line, at the point which best reflects your judgement.

\section{EXAMPLE}

x. In your opinion, what is a good day to go to the beach?

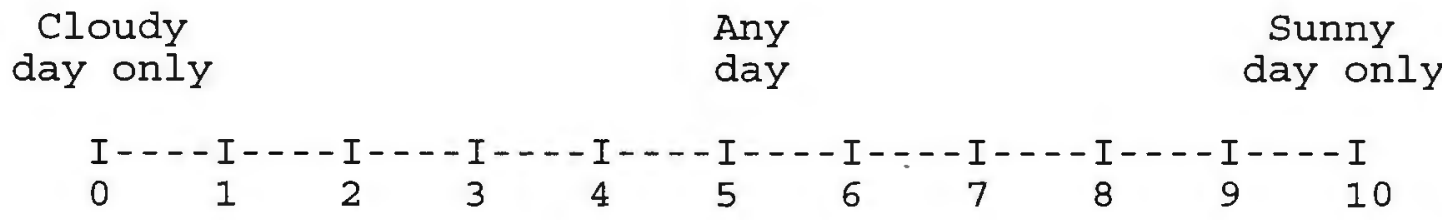

6. Regarding governmental environmental management decisions, do you feel that public involvement is, in general, a help or a hindrance to the sound execution of a project? (Please mark scale where appropriate.)

Hindrance

Does not

Help

matter

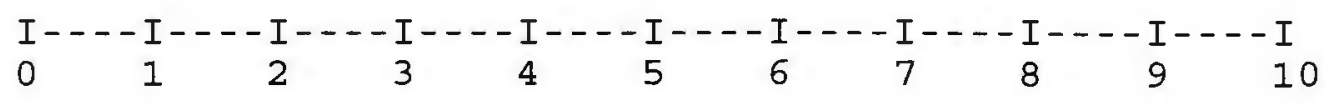


7. As you know, the federal superfund law (CERCLA) is up for reauthorization this year or next. All else being equal, do you think that Superfund's public involvement mandate should be increased or decreased in this revision?

Decrease

Keep it

Increase the same

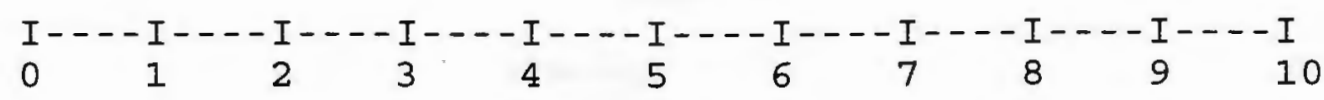




\section{Appendix C: List of Acronyms}

ADR: Alternative dispute resolution.

APA: Administrative Procedures Act, 5 U.S.C. Section 701 et seq.

ATSDR: US Agency for Toxic Substances and Disease Registry.

ARARs: Applicable and relevant or appropriate requirements. CDF: Confined disposal facility.

CERCLA: Comprehensive Environmental Response, Compensation, and Liability Act of 1980, amended in 1986 by SARA. 42 U.S.C. Sections 9601 et seq.

C.F.R.: Code of Federal Regulations.

CPFH: Concerned Parents of Fair Haven.

CWA: Clean Water Act, 33 U.S.C. 1251 et seg.

cy: Cubic yard.

DC: Downwind Coalition.

DRE: Dioxin removal efficiency.

EIS: Environmental impact statement.

ESD: Explanation of significant differences.

FS: Feasibility study.

FFA: Federal Facilities Agreement.

GNBCWG: Greater New Bedford Community Work Group.

HATR: Hands Across the River.

HRS: Hazard Ranking System.

HSPP: Hot Spot Proposed Plan.

LULU: Locally unwanted land use.

NEPA: National Environmental Policy Act of 1968, 42 U.S.C. 4321 et seg.

NIMBY: Not in my back yard.

NOAA: National Oceanic and Atmospheric Administration.

PAHs: Polyaromatic hydrocarbons. 
PCBs: Polychlorinated biphenols.

ppm: Parts per million.

PRP: Potentially responsible party.

RA: Risk assessment.

RI: Remedial investigation.

RAMP: Remedial Action Master Plan.

RCRA: Resource Conservation and Recovery Act, 42 U.S.C. 6901 et seq.

ROD: Record of Decision.

SARA: Superfund Amendments and Reauthorization Act of 1986, 42 U.S.C. Sections 9601 et seg.

SS: Statistically significant.

SSD: Statistically significant difference.

TAG: Technical advisory grant.

TSCA: Toxic Substances and Control Act of 1976, 15 U.S.C. Sections 2601 et seq.

U.S.C.: United States Code.

USDOE: US Department of Energy.

USEPA: US Environmental Protection Agency.

USGS: US Geological Survey. 


\section{Bibliography}

Adeola, F. O. 1994. Environmental hazards, health, and racial inequity in hazardous waste distribution. Environment and Behavior 26(1): 99-126.

In re Acushnet River and New Bedford Harbor: Proceedings re Alleged PCB Pollution (Acushnet IV), 712 F.Supp. 1019, 19 E.L.R. 21210, 100 A.L.R. 1 (1989, D.C.Mass.).

In re Acushnet River \& New Bedford Harbor: Proceedings re Alleged PCB Pollution (Acushnet VI), 722 F.Supp. 888 (D.Mass. 1989).

Alabama v. United States Environmental Protection Agency, 871 F.2d 1548, 29 Envt.Rep.Cas. 76, 19 E.L.R. 20956 (11th Cir. 1989) cert. denied 493 U.S. 991, 107 L.Ed.2d 535, 110 S.Ct. 538, 30 Envt.Rep.Cas. 2133, appeal after remand 925 F.2d 385, 19 F.R.Serv. 3d 117, 21 E.L.R. 21026 (11th Cir.).

Allen, S. 1993. Smoldering over an incinerator. Boston Globe, 16 september, 1 .

1992a. Firms settle waste suit in New Bedford. Boston Globe, 4 september, 1 and 23.

1992b. EPA bias charged in New Bedford's incinerator plan. Boston Globe, 14 September, 1 and 5 .

A.L.R. Fed.: See American Law Reports, Federal.

American Law Reports, Federal. 1981 (copyright). Rochester: The Lawyers Co-operative Publishing Co.

Arkansas Peace Center v. Dept. of Pollution Control, 999 F.2d. 1212 (8th Cir. 1993) cert. denied 128 L.Ed.2d 70, 114 S.Ct. 1397,62 U.S.L.W. 3657.

Bacow, L. S. and M. Wheeler. 1984. Environmental dispute resolution. New York: Plenum Press.

Bailey, C. and C. E. Faupel. 1989. Out of sight is not out of mind: public opposition to ocean incineration. Coastal Management 17: 89-102.

Balsam Environmental Consultants, Inc. 1990. Isopleths for total PCB concentrations [Acushnet River, New Bedford, Mass.]. Site map reprinted in USEPA 1989b, below. Salem, NH.

Blalock, H. M. 1979. Social statistics. New York: McGrawHill.

Bloomington v. Westinghouse Electric Corp., 824 F.2d 531, 17 E.L.R. 21185 (7th Cir. 1987). 
Brunner, C. R. 1985. Hazardous air emissions from incineration. New York: Chapman and Hall.

Burger, E. J. 1990. Health as a surrogate for the environment. Daedalus 119(4): 133-154.

Cabot Corp. v. United States Environmental Protection Agency, 677 F.Supp. 823, 27 Envt.Rep.Cas. 1523，18 E.L.R. 20835 (E.D.Pa. 1988).

Cardozo, M. S. (ed). 1976. The Portuguese in America, 590 b.c. to 1974: A chronology and fact book. Dobbs Ferry, NY: Oceana Publications.

Casner, A. et al. 1990. United States announces $\$ 66$ million agreement in principle with defendant in New Bedford Harbor PCB Superfund case. Press release, Sept. 4, 1990. Reprinted in USEPA 1990b, below, Vol. IX. USEPA Region I, Boston, MA.

Champion Map Corporation. 1990. Map of Fall River / New Bedford Massachusetts. No city: Champion Map Corporation.

Ciavettieri, F. 1994. Public statement at New Bedford Harbor Site Committee meeting, New Bedford Vocational - Technical High School, New Bedford, Mass., 12 July.

City of New Bedford. 1994. EPA at N.B. Voke. Videocassette recording of New Bedford Harbor site Committee meeting, New Bedford Vocational - Technical High School, New Bedford, Mass., 5 January. In the collection of the New Bedford Public Library.

Cleland-Hamnett, Wendy. 1993. The role of comparative risk analysis. EPA Journal 19(1): 18-23.

Cirone, P. and M. Coco. 1993. The lessons of Commencement Bay. EPA Journal $19(1): 33-34$.

Clarke, L. 1989. Acceptable risk? Making decisions in a toxic environment. Berkeley: University of California Press.

Code of Federal Regulations. 1993. Washington: US Government Printing Office.

Collins, P. 1993. Opponents of PCB incineration say they have clout to block it. The standard-Times (New Bedford), 16 July, 1 .

Conservation Law Foundation of N.E. V. Reilly, 950 F.2d 38 (1st Cir. 1991).

Corey, W. 1993. EPA shows off site to dredge, burn PCBs. The Standard-Times (New Bedford), 17 september, B1. 
Corey, W. 1993a. City tries to avoid EPA fines. The Standard-Times (New Bedford), 16 september, 1 and 5 .

Cormick, G. W. 1982. The myth, the reality, and the future of environmental mediation. Environment 24(7): 15-39.

1980. The "theory" and practice of environmental mediation. The Environmental professional $2(1): 24-33$.

Costner, P. and J. Thornton. 1990. Playing with fire. Monograph. Washington, D.C.: Greenpeace USA.

Covello, V. T. and J. Mumpower. 1985. Social benefit versus technological risk. In Environmental Risks and Hazards, ed. by S. L. Cutter, 33-55. Englewood Cliffs, N.J.: Prentiss Hall, 1994 .

Cushman, J. H. 1994. Congress forgoes its bid to speed cleanup of dumps. New York Times, 6 October, A1 and A22.

Cutter, S. L. (ed.) 1994. Environmental Risks and Hazards. Englewood Cliffs, N.J.: Prentiss Hall.

- 1993. Living with risk: the geography of

technical hazards. London: Edward Arnold.

1984. Risk cognition and the public: the case of Three Mile Island. Environmental Management 8(1): 15-20.

Cvetkovich, G. and T. C. Earle. 1992. Environmental hazards and the public. J. of Social Issues $48(4): 1-20$.

Dellarco, V. L. and C. A. Kimmel. 1993. Update on noncancer assessments. EPA Journal 19(1): 30-32.

Denton, M. E. and R. E. Dunlap. 1986. Environmentalism and elitism: A conceptual and empirical analysis. Environmental Management 10(5): 581-589.

Douglas, M. 1990. Risk as a forensic resource. Daedalus $119(4): 1-16$.

(1985). Risk acceptability according to the social sciences. Monograph. New York: Russell Sage Foundation.

Douglas, M. and A. M. Wildavsky. 1982. Risk and Culture. Berkeley: University of California Press.

Duckworth, Jackie, President of the Greater New Bedford Community Work Group, 1993. Personal communication, 13 March.

Edelstein, M. R. 1988. Contaminated communities: The social and psychological impacts of residential toxic exposure. Boulder, CO: Westview Press. 
Elliot, M. L. P. 1984. Improving community acceptance of hazardous waste facilities through alternative systems for mitigating and managing risk. Hazardous Waste 1(3): 397-410.

Ellis, L. B. 1892. History of New Bedford and its vicinity, 1602-1892. Syracuse: D. Mason and Co.

Environmental Law Institute. Superfund Deskbook. Washington, DC: Environmental Law Institute.

Environmental Research Foundation. 1992. Gore takes on the WTI incinerator. Rachel's Hazardous Waste News No. 315: 1-2.

F.2d: See Federal Reporter, 2nd Series, below.

F.3d: See Federal Reporter, 3rd Series, below.

F.Supp.: See Federal Supplement, below.

Farago, K. et al. 1989. Not in my town: conflicting views on the siting of a hazardous waste incinerator. Risk Analysis $9(4): 463-471$.

Farber, S. and A. Rambaldi. 1993. Willingness to pay for air quality: the case of outdoor excercise. Contemporary Policy Issues $11(4): 19-30$.

Farber, S. 1992. The economic cost of environmental risk: a case study in Louisiana. J. of Environmental Management 36 : $1-16$.

Federal Reporter, 2nd Series. 1987. St. Paul: West Publishing Co.

Federal Reporter, 3rd Series. 1994. St. Paul: West Publishing Co.

Federal Rules of Civil Procedure. 1994. St. Paul: West Publishing Co.

Federal Supplement. 1990. St. Paul: West Publishing Co.

Fenton, D. M. and G. J. Syme. 1989. Perception and evaluation of the coastal zone: implications for coastal zone planning. Coastal Management 17: 295-308.

Finkel, A. M. and D. Golding. 1993. Alternative paradigms. EPA Journal 19(1): 50-52.

Fiorino, D. J. 1989. Technical and democratic values in risk analysis. Risk Analysis 9(3): 293-299.

Firey, W. 1960. Man, mind, and land: a theory of resource use. Glencoe, IL: The Free Press. 
Fischer, J. 1993. Local governments and alternative dispute resolution. Public Management $75(8): 16-20$.

Florestano, P. S. and P. A. Rathbun. 1981. Public opinion and interest group position on Chesapeake Bay issues: implications for resource management. Coastal Zone Management Journal $9(1): 19-33$.

Fort, R. et al. 1993. Perception costs and NIMBY. J. of Environmental Management 38: 185-200.

Freudenburg, W. R. and S. K. Pastor. 1992. NIMBYs and LULUs: stalking the syndromes. J. of Social Issues $48(4): 39-61$.

Freudenburg, W. R. 1988. Perceived risk, real risk: social science and the art of probabilistic risk assessment. Science 242: 44-49.

Fullilove, J. 1994. Lawsuit attacks groundfish regs. National Fisherman $75(2): 11$.

Furuseth, O. J. 1990. Impacts of a sanitary landfill: spatial and non-spatial effects on the surrounding community. J. of Environmental Management 31: 269-277.

Gardner, G. T. and L. C. Gould. 1989. Public perceptions of the risks and benefits of technology. Risk Analysis 9(2): 225-242.

Garmon, Gayle, New Bedford Harbor Superfund Site Administrator. 1994. Personal communication, 31 May.

1993. Personal communication, 21 March.

Glass, P. and W. Corey. 1993. EPA is ready to force city to burn PCBs. The Standard-Times (New Bedford), 11 September, 1 and 5 .

Grigalunas, T. A. and J. J. Opaluch. 1989. Managing contaminated marine sediments: economic considerations. Marine Policy $13(4): 318-333$.

Goldstein, B. D. 1993. If risk management is broke, why fix risk assessment? EPA Journal 19(1): 37-38.

Greenberg, M. R. 1986. Health effects of environmental chemicals. In Environmental Risks and Hazards, ed. by S. L. Cutter, 297-309. Englewood Cliffs, N.J.: Prentiss Hall, 1994.

Greenberg, M. R. and R. F. Anderson. 1984. Hazardous waste sites: the credibility gap. New Brunswick, NJ: Center for Urban Policy Research (Rutgers University).

Gunn, Eileen, staff Geologist, Coalition for Buzzards Bay. 1994. Personal communication, 24 January. 
Haness, S. and J. Warwick. 1991. Evaluating the hazard ranking system. J. of Environmental Management 32: 165-176.

Hanford Downwinders V. Dowdle, 841 F.Supp. 1050 (E.D.Wash. 1993).

In re Hanford Nuclear Reservation Litigation, 780 F.Supp. 1551, 34 Envt.Rep.Cas. 1145, 22 E.L.R. 20703 (E.D.Wash. 1991).

Hatfield, T. H. 1988. A formal analysis of attitudes toward siting a hazardous waste incinerator. J. of Environmental Management 29: 73-81.

Heart of America Northwest v. Westinghouse Hanford, 820 F.Supp. 1265 (E.D.Wash.).

Hegerty, R. B. 1959. New Bedford's History. Monograph. New Bedford: Reynolds - DeWalt.

Helzlsouer, K. J. and L. Gordis. 1990. Risks to health in the United States. Daedalus 119(4): 193-206.

Hird, J.A. 1993. Environmental policy and equity: the case of Superfund. J. of Policy Analysis and Management 12(2): $323-343$.

Hobbs, B. F. and A. H. Voelker. 1978. Analytical multiobjective decision-making techniques and power plant siting: A survey and critique. Monograph. Oak Ridge, TN: Oak Ridge National Laboratory.

Jacobs, H. M. and R. Rubino. 1987. Environmental mediation: An annotated bibliography. Council of Planning Librarians Bibliography \#189. Chicago: Council of Planning Librarians.

Jasanoff, S. 1993. Relating risk assessment and risk management. EPA Journal $19(1): 35-37$.

1990. American exceptionalism and the political acknowledgement of risk. Daedalus 119(4): 61-82.

1986. Risk management and political culture. Monograph. New York: Russell Sage Foundation.

Johnson, W.B. 1990. Annotation: Right to intervene in Federal hazardous waste enforcement action. 100 A.L.R. Fed. $\underline{35}$.

1993. Propriety of negotiated settlement in government cleanup actions under federal hazardous waste statutes. 114 A.L.R. Fed. 1.

Johnston, R. K. and D. W. Nixon. 1992. Cleaning up hazardous waste disposal sites in the coastal zone: A review of the federal and state legal requirements for remediation at Allen 
Harbor, Narragansett Bay, Rhode Island. In Organizing for the coast: proceedings of the thirteenth annual conference of the Coastal Society, April 5-8, 1992. Washington, D.C.: The Coastal Society.

Kasperson, R. E. et al. 1992. Social distrust as a factor in siting hazardous facilities and communicating risks. J. of Social Issues $48(4): 161-187$.

Kasperson, R. E. 1986. Six propositions on public participation and their relevance for risk communication. Risk Analysis 6(3): 275-281.

Lave, L. B. 1989. Risk assessment and regulatory priorities. In Environmental Risks and Hazards, ed. by S. L. Cutter, 269273. Englewood Cliffs, N.J.: Prentiss Hall, 1994.

Lewis, H. W. 1990. Technological Risk. New York: Norton.

Linstone, H. A. and M. Turoff (eds.) 1975. The Delphi Method: techniques and applications. Reading, MA: Addison Wesley.

Lone Pine Steering Committee v. U.S. E.P.A., 777 F.2d 882 (3rd Cir.) cert. denied 106 S.Ct. 1970, 476 U.S. 1115, 90 L.Ed.2d 654 (1985).

Lone Pine Steering Committee V. U.S.E.P.A., 600 F.Supp 1487 (1985).

Lowi, T. J. 1990. Risks and rights in the history of American governments. Daedalus $119(4): 17-40$.

Lowry, Sue Ellen, Sierra Club Legal Defense Fund, 1994. Personal communication, April.

Massachusetts General Laws Annotated, Volume 2. 1993. St. Paul: West Publishing Co.

Massachusetts Office of Dispute Resolution. 1993. Progress Report [1990 - 1993]. Monograph. Boston: Massachusetts Office of Dispute Resolution.

Mays, R. H. 1988. Alternative dispute resolution and environmental enforcement: A noble experiment or a lost cause? Environmental Law Reporter 18: 10087 - 10097.

Miller, A. 1985. Psychological biases in environmental judgements. J. of Environmental Management 20: 231-243.

M.G.L. 1993. See Massachusetts General Law 1993.

Morrison, D. E. and R. E. Dunlap. 1986. Environmentalism and elitism: a conceptual and empirical analysis. Environmental Management 10(5): 581-589. 
Mosher, L. 1983. EPA, looking for a better way to settle rules disputes, tries some mediation. National Journal $15(10): 504-506$.

Nakamura, R. T. et al. 1991. Environmental dispute resolution and hazardous waste cleanups: A cautionary tale of policy implementation. J. of Policy Analysis and Management $10(2)$ : 204-221.

Neighborhood Toxic Cleanup Emergency v. Reilly, 716 F.Supp. 828, 30 Envt.Rep.Cas. 1375, 19 E.I.R. 21165 (D.N.J. 1989).

Nesnow, S. 1993. Breakthroughs in cancer risk assessment. EPA Journal 19(1): 27-29.

New Bedford City Council, New Bedford, Massachusetts 1993. An Ordinance: Transportation of Mechanism for Incineration and Water Treatment. June 10 .

New Orleans Public Service, Inc. v. United Gas Pipe Line, 732 F.2d 452, (5th Cir.) (en banc) cert. denied sub nom. Morial v. United Gas Pipe Line Co. 469 U.S. 1019, 105 S.Ct. 434, 83 L.Ed.2d 360 (1984).

O'Hare, M. and D. Sanderson. 1993. Facility siting and compensation: Lessons from the Massachusetts experience. J. of Policy Analysis and Management $12(2): 364-376$.

Patton, D. E. 1993. The ABCs of risk assessment. EPA Journal. 19 (1) 10-15.

Parker, P. E. 1994. Weld, Indians sign casino pact. Providence Journal, August 24, A1 and A6.

Peck, D. L. (ed.) 1989. Psychosocial effects of hazardous toxic waste disposal on communities. Springfield, Illinois: Charles C. Thomas.

J. V. Peters v. Ruckelshaus, 584 F.Supp. 1005 (N.D.Ohio, E.D.1984).

Popper, F. J. 1981. Siting LULUs. Planning 47: 12-15.

Pollack, S. 1994a. Bay state fishermen rally against groundfish, scallop plans. National Fisherman 75(1): 14 .

Pollack, S. 1994b. Disaster relief funding sought to keep Northeast fishermen afloat. National Fisherman: 75(1): 14-15.

Portney, K. E. 1985. The potential of the theory of compensation for mitigating public opposition to hazardous waste treatment facility siting: Some evidence from five Massachusetts communities. Policy Studies Journal $14(1): 81-$ 89. 
Pruell, R. J. et al. 1990. Geochemical study of sediment contamination in New Bedford Harbor, Massachusetts. Marine Environmental Research 29:77-101.

Preuss, P. W. and W. H. Farland. 1993. A flagship risk assessment. EPA Journal 19(1): 24-26.

Rabe, B. G. 1988. The politics of environmental dispute resolution. Policy Studies Journal 16(3): 585-601.

Reardon V. U.S., 947 F.2d 1509, 34 Envt.Rep.Cas. 1070, 22 E.L.R. 20292 (1st Cir. 1991).

Redland Soccer Club v. Dept. of Army, 801 F.Supp. 1432 (M.D.Pa. 1992).

Reynolds v. Lujan, 785 F.Supp. 152 (D.N.M. 1992).

Richards, J. 1990. Units of analysis and the individual differences fallacy in environmental assessment. Environment and Behavior 22(3): 307-319.

Rubino, R. G. and H. M. Jacobs. 1990. Mediation and negotiation for planning, land use management, and environmental protection: An annotated bibliography for the period 1980 - 1989. Council of Planning Librarians Bibliography \# 264. Chicago: Council of Planning Librarians.

Russell, M. and M. Gruber. 1987. Risk assessment in environmental policy-making. Science 236: 286-290.

S.Ct.: See West's Supreme Court Reporter.

Samdahl, D. M. and R. Robertson. 1989. Social determinants of environmental concern. Environment and Behavior 21(1) : 5781 .

Sapolsky, H. M. 1990. The politics of risk. Daedalus $119(4): 83-96$.

SAS Institute, Inc. 1985. SAS introductory quide for personal computers, Version 6 Edition. Cary, N.C.: SAS Institute, Inc.

SAS Institute, Inc. 1985. SAS procedures guide for personal computers, Version 6 Edition. Cary, N.C.: SAS Institute, Inc.

Schahn, J. and E. Holzer. 1990. Studies of individual environmental concern: The role of knowledge, gender, and background variables. Environment and Behavior $22(6)$ : 767 786 .

Schalk V. Reilly, 900 F.2d 1091, 31 Envt.Rep.Cas. 1281, 20 E.L.R. 20669, reh. den., en banc, (7th Cir. 1990) cert. denied Frey V. Reilly, 498 U.S. 981, 112 L.Ed.2d 521, 111 S.Ct. 509, 
32 Envt.Rep.Cas. 1976, reh. den. 498 U.S. 1074, 112 L.Ed.2d 863,111 S.Ct. 802 .

Scheuplein, R. J. 1993. Uncertainty and the 'flavors' of risk. EPA Journal 19(1): 16-17.

Sebastian, James, USEPA Region I Community Relations. 1993. Personal communication, 19 March.

Shaw, Dennis, Office of Congressman Barney Frank. 1994. Personal communication, 3 August.

Sheehan, H. E. and R. P. Wedeen, eds. 1993. Toxic circles: Environmental hazards from the workplace into the community. New Brunswick, N.J: Rutgers University Press.

Shephards Federal Citations, 7th Edition. 1990 (copyright). Colorado Springs: McGraw-Hill.

Siegal, S., and N. J. Castellan. 1988. Nonparametric statistics for the behavioral. Sciences. New York: McGrawHill.

Slovic, P. 1987. Perception of risk. Science 236: 280-285.

Starr, C. 1969. Social benefit versus technological risk. Science 165:1232-1238.

State of Arizona v. Motorola, Inc., 139 F.R.D. 141 (D. Ariz. 1991).

Teuber, A. 1990. Justifying risk. Daedalus 119(4): 235-254.

Turoff, M. 1975. The policy delphi. In The delphi method: Techniques and applications, ed. by $M$. Turoff and $H$. A. Linstone. Reading, MA : Addison-Wesley.

Tye, L. 1987. New Bedford Harbor shows perils of pollution. Boston Globe, October 26, 22.

United Church of Christ, Commission for Racial Justice. 1987. Toxic wastes and race in the United States: A national report on the characteristics of communities with hazardous waste sites. Monograph. United Church of Christ, New York, NY.

United states Supreme Court Digest. Various copyrights. St. Paul: West Publishing Co.

United States V. ABC Industries, 153 F.R.D. 603 (W.D. Mich. 1993).

United states V. Acton Corp. on behalf of Vikoa, 131 F.R.D. 431 (D.N.J. 1990).

United States v. AVX Corporation (1st Cir. 1992) 962 F.2d 108 . 
United States v. Azko Coatings of America, Inc., 719 F.Supp. 371 (E.D.Mich. 1989).

United States V. Azko Coatings of America, Inc., 949 F.2d 1409, 22 E.L.R. 20405, (6th Cir. 1991).

United States v. BASF-Inmont Corp. 819 F. Supp. 601 (E.D.Mich. 1993).

United States v. Bliss, 132 F.R.D. 58 (E.D.Mo. 1990).

United states $v$. City of New Bedford, Massachusetts. Civil Action No. 93-12080-Y, U.S.D.C.D. Mass., 12 October 1993.

United States v. Princeton Gamma-Tech, 31 F.3d 138 (3rd Cir. 1994).

United States v. Rohm \& Haas Co., 669 F.Supp. 672 (D.N.J. 1987).

United States v. Seymour Recycling Corp., 679 F.Supp. 859 (S.D.Ind. 1987).

United states v. State of Colorado, 990 F.2d 1565 (10th Cir. 1993), cert. denied 127 L.Ed.2d 216, 114 S.Ct. 922 (1994).

United States Environmental Protection Agency. See generally USEPA.

United States Environmental Protection Agency v. Environmental Waste Control, 917 F.2d 327 (7th Cir. 1990).

U.S.: See United States Supreme Court Digest.

U.S.C. See US Code.

US Code. 1988 (updated). Washington: US Government Publishing Office.

U.S.C.S. See US Code Service.

US Code Service, Lawyers' Edition. 1987. Rochester: The Lawyers Co-operative Publishing Co.

US Congress. 1986. Joint Explanatory Statement of the Committee of Conference (H.Conf.Rep. No.99-962), reprinted in 1986 U.S.Code Cong. \& Admin. News $3276,3317$.

US Congress. House. Committee on Public Works and Transportation. 1990. Contaminated Sediments: Hearings before the subcommittee on Water Resources. 101st Cong., 2nd Sess., 15 and 16 May.

US Department of Commerce. 1993. Statistical Abstract of the United States 1993. Washington, DC: US Government Printing Office. 
US Department of Commerce. 1992a. 1990 Census of population. General population characteristics: Massachusetts. $1990 \mathrm{CPH}-$ 1-23. Washington, DC: US Government Printing office.

US Department of Commerce. 1992b. 1990 Census of population. Social and economic characteristics: Massachusetts. $1990 \mathrm{CPH}-$ 2-23. Washington, DC: US Government Printing office.

US Department of Commerce. 1992c. 1990 Census of population and housing. Summary social, economic and housing characteristics: Massachusetts. 1990 CPH-5-23. Washington, DC: US Government Printing Office.

US Environmental Protection Agency. See USEPA.

US House of Representatives. 1994. The Superfund Reform Act of 1994. Title I - Community Participation and Human Health. 103rd Cong., H.3800. Washington, D.C.

US Senate. 1994. A bill to amend the Comprehensive Environmental Response, Compensation, and Liability Act of 1980 , and for other purposes. Title I - c community Participation and Human Health. , 103rd Cong., S.1834. Washington, D.C.

USEPA. 1992a. EPA proposes cleanup plan to address contamination in the Estuary and Lower Harbor / Bay at the New Bedford Harbor Superfund Site. Monograph. USEPA Region I, Boston, MA.

USEPA. 1992b. EPA proposes expanded cleanup plan to address contamination in parts of upper Buzzards Bay, New Bedford Harbor Superfund Site. Monograph. USEPA Region I, Boston, MA.

USEPA. 1992c. Explanation of significant differences, New Bedford Harbor site / Hot Spot Operable Unit, New Bedford, Massachusetts. Monograph. USEPA Region I, Boston, MA.

USEPA. 1990a. Record of decision for the Hot spot operable Unit at the New Bedford Harbor Superfund Site in New Bedford, Massachusetts. Monograph. USEPA Region I, Boston, MA.

USEPA. 1990b. New Bedford Harbor NPL Site, Estuary and Lower Harbor / Bay Operable Unit: Administrative Record, Vols. I-IX. Boston: US Environmental Protection Agency, Region I, Waste Management Division.

USEPA. 1990C. Responsiveness Summary, New Bedford Harbor Superfund Site, Hot Spot Operable Unit, New Bedford, Massachusetts. Monograph. USEPA Region I, Boston, MA.

USEPA. 1989a. EPA proposes cleanup plan for the Hot Spot area of the New Bedford Harbor Superfund Site. Monograph. USEPA Region I, Boston, MA. 
USEPA. 1989b. New Bedford Harbor NPL Site (Hot Spot Operable Unit): Administrative Record, V. I-XLV. Boston: US Environmental Protection Agency, Region I, Waste Management Division.

USGS. 1979. New Bedford North, Mass. (1:25,000 topographic map). United States Geological Survey, Reston, VA.

USGS. 1979. New Bedford South, Mass. (1:25,000 topographic map). United States Geological Survey, Reston, VA.

duVair, P. and J. Loomis. 1993. Household valuation of alternative levels of hazardous waste risk reduction, using referendum format CVM. J. of Environmental Management 39: $143-155$.

Varis, 0. 1989. The analysis of preferences in complex environmental judgements - - A focus on the analytic hierarchy process. J. of Environmental Management 28: 283-294.

Verba, S. et al. 1993. Citizen activity: who participates? What do they say? American Political Science Review 87(2): 308-318.

Weinberg, A. M. 1985. Science and its limits: the regulator's dilemma. In Environmental Risks and Hazards, ed. by S. L. Cutter. Englewood Cliffs, N.J.: Prentiss Hall, 1994. Pp 257-268.

Wells, Jane, Massachusetts Office of Dispute Resolution. 1994. Personal communication, 24 May.

West, N. 1993. Lab manual: Quantitative methods in marine affairs. Kingston, RI: Department of Marine Affairs, University of Rhode Island.

West, N. 1989. A preliminary review of water quality parameters and recreational user perceptions of nearshore water quality. J. of Coastal Research 5(3): 563-572.

West's Supreme Court Reporter. Various copyrights. St. Paul: West Publishing Co.

Wildavsky, A. and K. Dake. 1990. Theories of risk perception: Who fears what and why? Daedalus 119(4): 41-60.

Williams, E. 1993. What claims fall within limitation imposed by Sxn. $113(\mathrm{~h})$ of Comprehensive Environmental Response, Compensation, and Liability Act (CERCLA) (42 USCS $9613(\mathrm{~h})$ ) on judicial review of cases arising under CERCLA. 116 A.L.R. Fed. 69.

Wilson, G. 1992. A survey on attitudes of landholders to native forest on farmland. J. of Environmental Management 34: 117-136. 
Wilson, R. and E. A. C. Crouch. 1987. Risk assessment and comparisons: an introduction. In Environmental Risks and Hazards, ed. by S. L. Cutter, 236-243. Englewood Cliffs, N.J.: Prentiss Hall, 1994. 